


\section{Fish \& Wildlife 2000 \\ National Strategy Plans} DENVER, COLORADO 80225

Component Plans include implementation strategies for specific goals and objectives outlined in Fish and Wildlife 2000 - A Plan for the Future.

\section{Fish}

Fisheries Habitat Management

Anadromous Fish Habitat Management

\section{Wildlife}

Waterfowl Habitat Management

Wetlands Environment Today \& Tomorrow

Desert Bighorn Sheep Habitat Management

Raptor Habitat Management

Watchable Wildlife

Neotropical Migratory Bird Habitat Conservation

Upland Game Bird Habitat Management

Big Game Habitat Management

\section{Threatened/Endangered Species}

Desert Tortoise Habitat Management

Special Status Plant Management

Special Status Fishes Habitat Management

\section{Administrative}

Wildlife and Fisheries Information System

Career Management Team Findings for Wildlife and Fisheries Biologists

Training BLM Wildlife and Fisheries Program Personnel

Staffing for the BLM Wildlife and Fisheries Program 


\title{
Special Status Fishes Habitat Management
}

\author{
Prepared by \\ U.S. Department of the Interior \\ Bureau of Land Management \\ Special Status Fishes Team
}

Jack E. Williams

Fisheries Program Manager, Washington, D.C.

Neil B. Armantrout

Biologist, Eugene District, Oregon

Henri R. Bisson

District Manager, Phoenix District, Arizona

Osborne Casey

Fisheries Biologist, Nevada State Office

Ted E. Cordery

Biologist, Arizona State Office

Michael R. Crouse

Chief, Branch of Range, Watershed \& Wildlife

Oregon State Office

E. Philip Pister

Executive Secretary, Desert Fishes Council

Dennis L. Tol

Biologist, Winnemucca District, Nevada

May 1991

BLM/SC/PT-91/005+6844 



\section{Acknowledgments}

A work such as this could not be completed without the assistance and support of many individuals. In addition to the authors listed, other outside reviewers included: David L. Soltz, Donna L.

Withers, Gail C. Kobetich, Paul B. Holden, and James E. Johnson. E.P. Pister graciously furnished many photos used in the final publication.

Sherman Gillespie spent many hours compiling and drafting the distribution maps while Jan Poorman and Linda Hill spent many hours on the editing assignment. Ray Boyd, Wildlife Biologist, ably handled the logistics of initial printing specifications, forms, routing of edited copy, and assistance in the final layout and publishing of the report.

Personnel of the Technology Transfer Staff at the Service Center did their usual fine job in the layout, design, and page makeup of the final draft. 



\section{Director's Preface}

At first glance, management of special status fishes on public lands might seem to be limited to pupfish in southern California or springfish in Nevada. It will be a surprise to many to learn that $\$ 12$ endangered, threatened, candidate, sensitive, and State-listed fishes occur on BLM lands. In addition to the "desert fishes" of the Southwest, BLM manages habitat of threatened and candidate salmon populations in California and Idaho, more than a dozen rare forms of trout scattered throughout the West, and an endangered species of "minnow" that reaches 80 pounds in the Colorado River drainage!

Our public lands are managed under a multipleuse framework that often includes livestock grazing, mining, and timber production-all activities that may threaten aquatic resources if not properly managed. Yet, I have seen streams where new grazing strategies have actually increased flows. We can restock the
Bonneville cutthroat trout in Wyoming and Utah, and still provide for cattle grazing. It is seldom easy, but our goals for special status fishes are achievable with minimal conflicts.

This document provides a detailed and ambitious strategy for conservation of rare fishes on BLM lands in Arizona, California, Colorado, Idaho, Montana, Nevada, New Mexico, Oregon, Utah, Washington, and Wyoming. BLM is dedicated to achieving the goals of this strategy, but we realize that to be successful, we must also rely on assistance from other Federal agencies, State governments, and the private sector. Simply put, we are all in this together!

As part of our growing Fish \& Wildlife 2000 strategy, I am pleased to approve and endorse this strategy plan for management of speeial status fishes and their ecosystems on public lands.

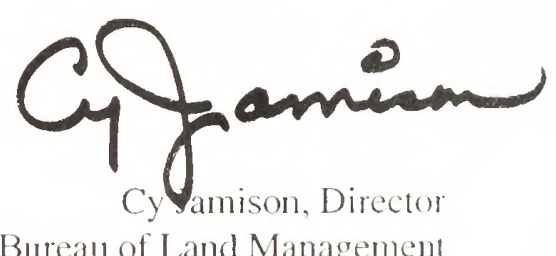

Bureau of Land Management 



\section{Contents}

Executive Summary

Introduction

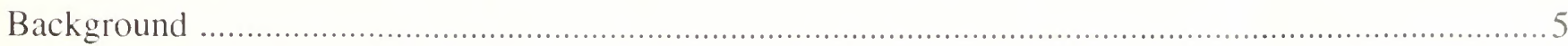

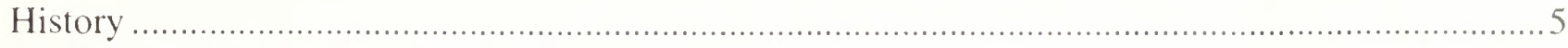

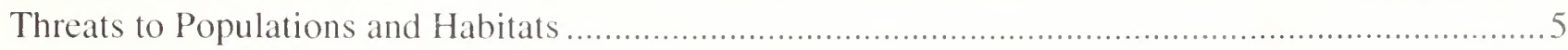

Early Management Efforts .................................................................................... 11

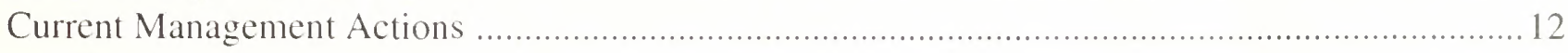

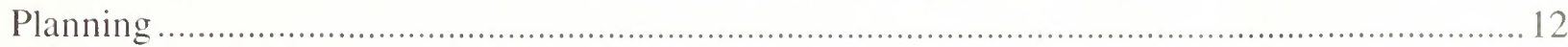

Habitat Restoration, Protection, and Acquisition ...................................................... 13

Water Rights and Water Quality Protection ............................................................ 15

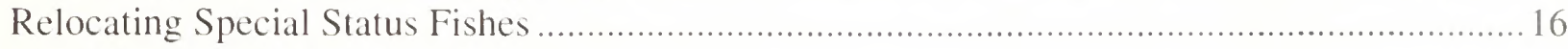

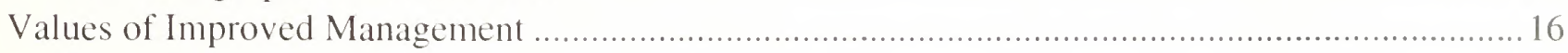

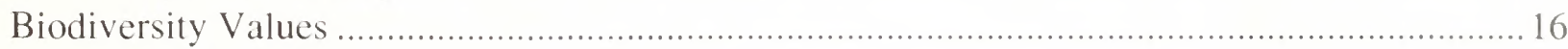

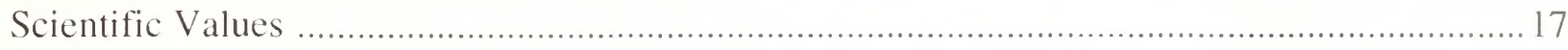

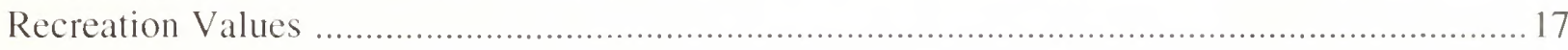

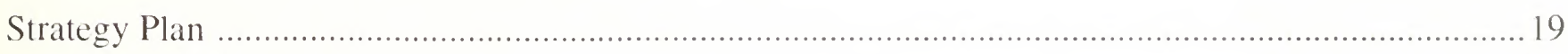

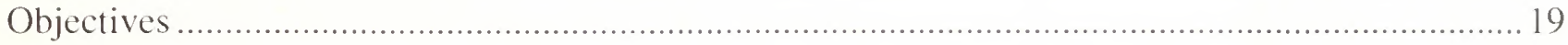

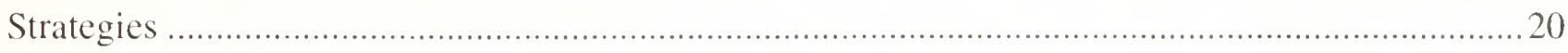

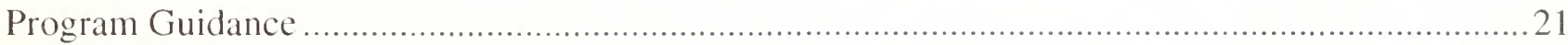

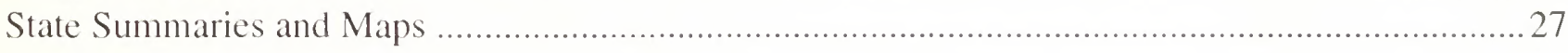

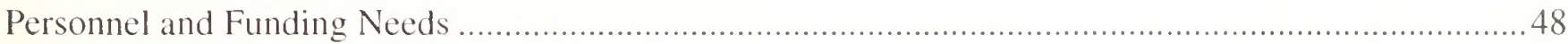

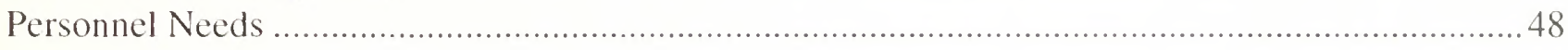

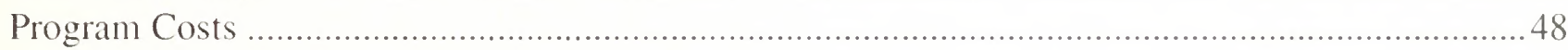

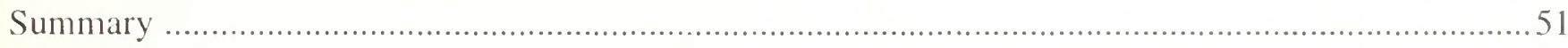

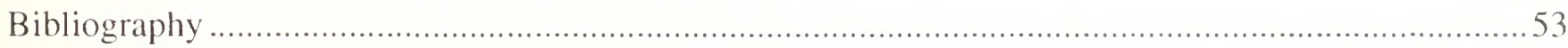





\section{Tables}

Table 1. Inventories needed from fiscal years 1991 through 2000 for special status fishes on public lands

Table 2. Activity plans needed from fiscal years 1991 through 2000 for special status fishes on public lands

Table 3. Research and studies needed from fiscal years 1991 through 2000

for special status fishes on public lands

Table 4. Habitat acquisitions needed from fiscal years 1991 through 2000 to

protect special status fishes on public lands

Table 5. Number of habitat improvements needed from fiscal years 1991 through

2000 for special status fishes on public lands

Table 6. Monitoring needed from fiscal years 1991 through 2000 for

special status fishes on public lands

Table 7. Special status fishes of Arizona

Table 8. Special status fishes of California

Table 9. Special status fishes of Colorado

Table 10. Special status fishes of Idaho

Table 11. Special status fishes of Montana 36

Table 12. Special status fishes of Nevada 38

Table 13. Special status fishes of New Mexico 40

Table 14. Special status fishes of Oregon

Table 15. Special status fishes of Utah .44

Table 16. Special status fishes of Wyoming 46

Table 17. Summary of plan implementation costs 49

\section{Figures}

Figure 1. Number of BLM fisheries biologists by state in 1989 versus number of special status fishes on public lands in that state 


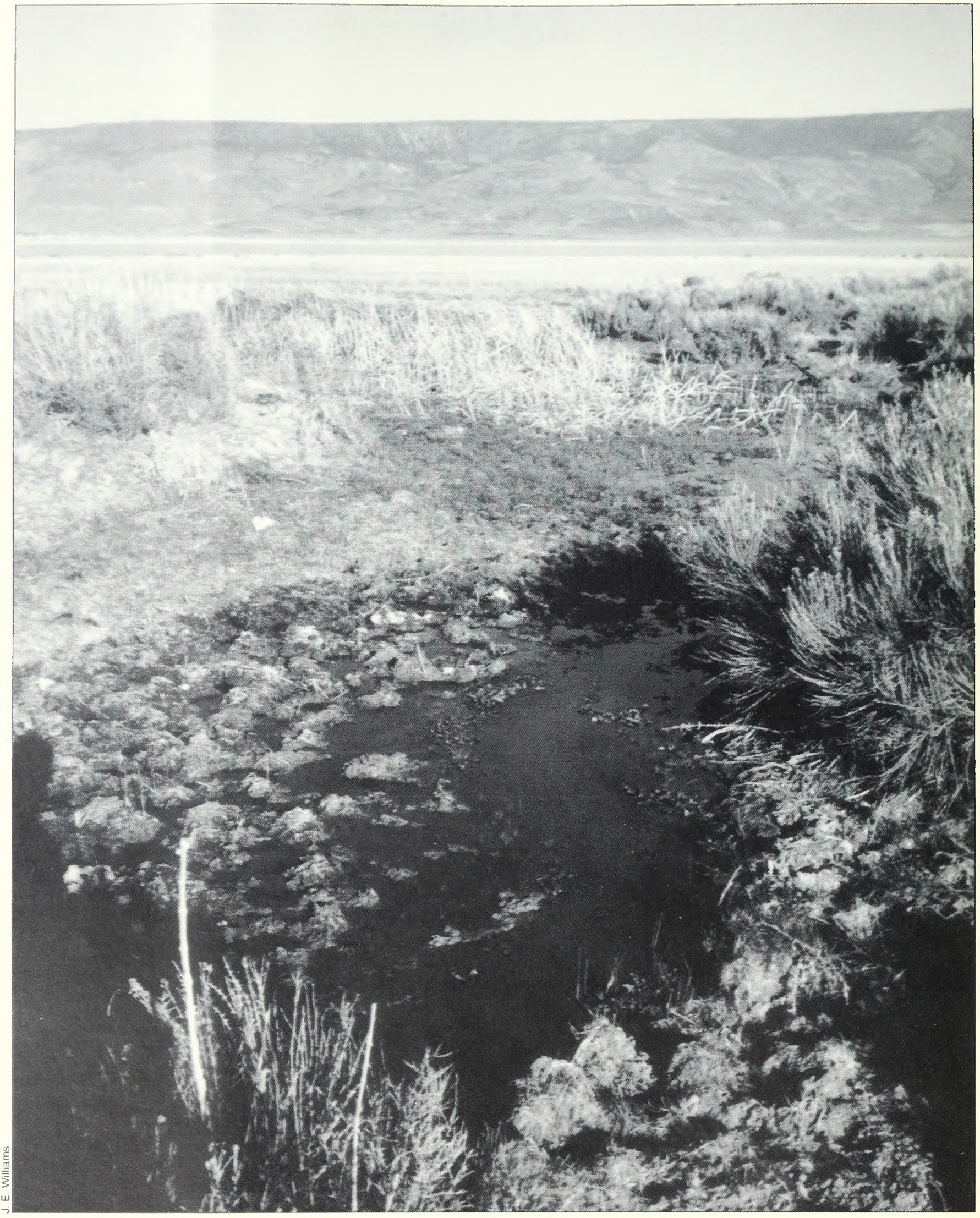

Foskett Spring, Oregon. This spring is the only native habitat for the Foskett speckled dace, a species listed as threatened. Since this photograph was taken, the spring has been acquired by BLM and fenced to exclude cattle. 


\section{Executive Summary}

The Bureau of Land Management (BLM) administers a wide variety of vital aquatic habitats throughout the western United States, including 155,000 miles of fishable streams, more than 4 million acres of lakes and reservoirs, and numerous isolated springs. Among the bountiful resources on public lands are 39 species of fish listed as threatened or endangered by the U.S. Department of the Interior, and 73 species considered to be candidate, BLM-sensitive, or State-listed species.

These species require special management consideration because of their dwindling numbers and deteriorating habitats. Also, the limited distribution of many special status fishes in small creeks and springs increases their vulnerability to habitat change. Thus, careful management is required.

Twenty of the 39 threatened or endangered fishes were listed by the Department of the Interior within the past 10 years. With demands for dwindling water supplies increasing as the West becomes more populous, the needs of special status species must be incorporated as a critical part of BLM's planning efforts.

Recovery of these rare fishes would result in substantial recreational and scientific benefits. Many forms of rare trout, for example, are adapted to harsh desert streams that cannot support typical hatchery strains of rainbow trout. Restoration of the degraded trout habitats would allow development of recreational fisheries. Restored habitats also would benefit a variety of lesser-known species that depend upon wellfunctioning aquatic systems.

Governed by numerous laws, regulations, and policies, principally founded on the Endangered Species Act and Bureau Manual Section 6840Special Status Species Management, the Bureau mandate is clear: to protect and recover threatened and endangered species and their habitats. Candidate species should be managed so as to prevent their being listed as threatened or endangered.
In 1987, the BLM Director approved Fish and Wildlife 2000: A Plan for the Future, which established national goals and objectives for managing fish and wildlife resources on public lands. A Special Status Fishes Team was established to develop specific strategies needed to maintain, protect, and enhance special status fishes and their habitats as set forth in the plan. The strategy also provides Bureau managers with the guidance necessary to more effectively manage fisheries and associated resources.

This strategy plan outlines a 10-year program for fiscal years 1991 through 2000. It is designed to meet the objectives for special status fishes as provided in Fish and Wildlife 2000. This would be achieved through improved activity planning; habitat restoration, protection, and acquisition; water rights and water quality protection; and reestablishment of special status fishes into historic habitats.

Implementing the strategy plan will result in the following accomplishments:

\section{Federal}

- completely recover 11 fish species

- reclassify 8 fish species from endangered to threatened status

- prevent extinction of 11 additional fishes

\section{Other}

- completely recover 6 State-listed species

- prevent the need to list 18 candidate species

- prevent extinction of 33 other species

Protection of special status fishes and their habitats constitutes responsible management from BLM in its stewardship of public lands and a positive step toward protecting the fishery resource and habitats for generations to come. 



\section{Introduction}

The Bureau of Land Management (BLM) manages over 155,000 miles of fishable streams, more than 4 million acres of lakes and reservoirs, and a wide variety of spring, marsh, and other important aquatic habitats. Fisheries resources managed by BLM on public lands contribute nearly $\$ 100$ million annually to the economy.

Among the bountiful resources on BLM lands are 39 species of fishes listed as threatened or endangered fishes of the mainstem Colorado River, for example, are endangered, threatened, or proposed for such classification. Many anadromous fishes, including certain salmon and steethead stocks, also are threatened with extinction. For those special status fishes residing in larger river systems, flows often have been depleted for human demands while remaining habitat has been fragmented by dams and reservoirs.

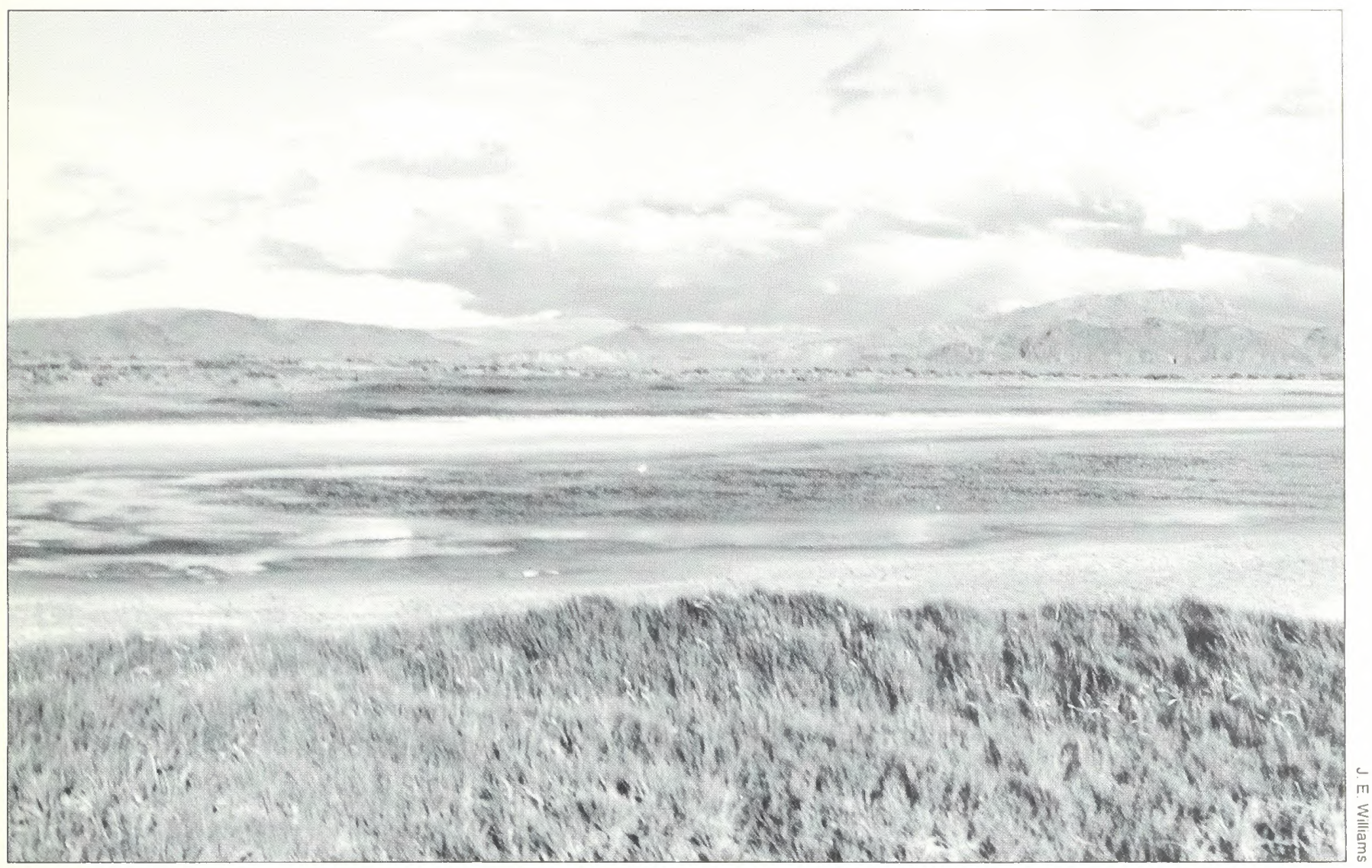

Lower Borax Lake, Oregon. This is the only publicly-owned habitat for the endangered Borax Lake chub.

by the U.S. Department of the Interior, and 73 species considered to be candidate, BLM-sensitive, or Statelisted. Special status fish resources occur on public lands in every western state except Alaska. Many of these special status fishes are found in arid regions and have been isolated in small creeks or springs since the end of the last ice age. Because of their limited distribution, they are especially vulnerable to habitat change.

An increasing proportion of special status fishes are found in large river systems. Many of the native
Numerous laws, regulations, Bureau policies, and Memorandums of Understanding (MOUs) mandate protection of special status fishes and their habitats. The Endangered Species Act of 1973, as amended, not only includes provisions for protection of listed species, but directs all Federal agencies to utilize their authorities in furthering the purposes of the Act, which are "...to provide a means whereby the ecosystems upon which endangered species and threatened species depend may be conserved." BLM must work closely with the Fish and Wildlife Service, National Marine 
Fisheries Service, and State governments during implementation of the Endangered Species Act.

Additional protection is afforded by the Federal Land Policy and Management Act, Fish and Wildlife Coordination Act, and National Environmental Policy Act.

In 1987, the BLM Director approved Fish and Wildlife 2000: A Plan for the Future. This strategy sets forth national goals and objectives for more effective management of fish and wildlife resources on the public lands, including anadromous, resident, and special status fishes. As a followup to Fish and Wildlife 2000, a team was established to develop strategies to guide future BLM actions for the management of special status fishes and thereby help achieve the threatened and endangered species objectives of the Fish and Wildlife 2000 strategy. This report, which was prepared by an interdisciplinary team, summarizes current management and outlines a 10year program (fiscal years 1991-2000) to maintain, protect, and enhance special status fishes and their habitats. 


\section{Background}

\section{History}

The present fish fauna of western North America is a result of the historic changes imposed on the natural system. Past movements of fishes have been influenced by geologic and hydrologic history. The advance and recession of glaciers, uplift and erosion of mountains, rise and fall of oceans, and reconfiguration of drainage patterns all contributed to the evolution of aquatic systems and the opportunities for fish to move into new areas and to survive over time.

Some species were better able to colonize new areas and to survive long-term changes in habitat condition. Where habitats were abundant and fairly stable, a greater variety of species became established. Fewer migratory pathways and a smaller range of habitats led to lower faunal diversity. If the migratory pathways were broken, populations became separated and disparate stocks began to evolve.

East of the Rocky Mountains, the Mississippi River provided a giant dispersal corridor for fishes across half the continent. Differing conditions in this large basin led to localized changes in fish communities, leaving a mixture of widespread species and species more limited in range and adapted to localized conditions.

Other river systems, such as the Rio Grande and the Colorado River, became isolated. In a system where fish habitats ranged from the high altitude snowinelt streams to the flat, arid deserts, a fauna low in species numbers but diverse in adaptations developed.

To the west, other river systems flowed into the Pacific Ocean. Past connections to the Mississippi and other basins to the east permitted many species to move westward into these rivers, resulting in a fauna much more diverse in the fossil record than is now found. The Pacific Ocean provided an alternative feeding ground and migratory route, resulting in a high percentage of native fishes in the coastal rivers that developed anadromous habits or exhibited some degree of salinity tolerance.

In between the major river systems were isolated basins. Once connected to one or more of the major rivers, they became isolated by the desiccation following the last ice age. Remaining habitats were streams originating on mountains, then flowing into lakes or playas, and a range of isolated spring systems. Fishes once living in the large pluvial lakes or rivers of the Great Basin either adapted to the much more confined habitats of the springs and small rivers or perished.

The resulting fish fauna in the West shows a high degree of endemism, a result of the imposed isolation and the restrictions of the available habitat. Away from the more abundant fauna of the Mississippi, the western fish fauna was challenged more by the harshness of the environment than the pressures of competition.

As the West was settled, habitats changed. Loss of habitat, particularly as a result of water removal, eliminated many fishes. Reservoir construction resulted in conditions more suitable to the many nonnative species that were introduced. In altered habitats, many native fishes suffered from new predation and competition pressures and were, therefore, displaced.

Distinctive faunas remain in the Pacific coastal drainages, Colorado and Rio Grande basins, the upper Mississippi, and the isolated basins of the Intermountain area. As a result of the introduction of nonnative species and alterations to the habitats, many populations and species are in precarious positions, requiring special management. Restoring and maintaining habitat remains the key to the survival of these fishes, together with controlling competition and predation from nonnative species.

\section{Threats to Populations and Habitats}

Alteration of aquatic habitats began when settlers started clearing land and harnessing streams and lakes for human uses. Streams were dammed and water diverted for irrigation. Many streams were choked with beaver dams and woody debris, creating broad marshy areas with dense vegetation. Flooding during peak runoff was extensive. Beaver dams were removed, woody debris pulled from streams, and channels deepened to hasten runoff and make more lands available for settlement and agriculture. 


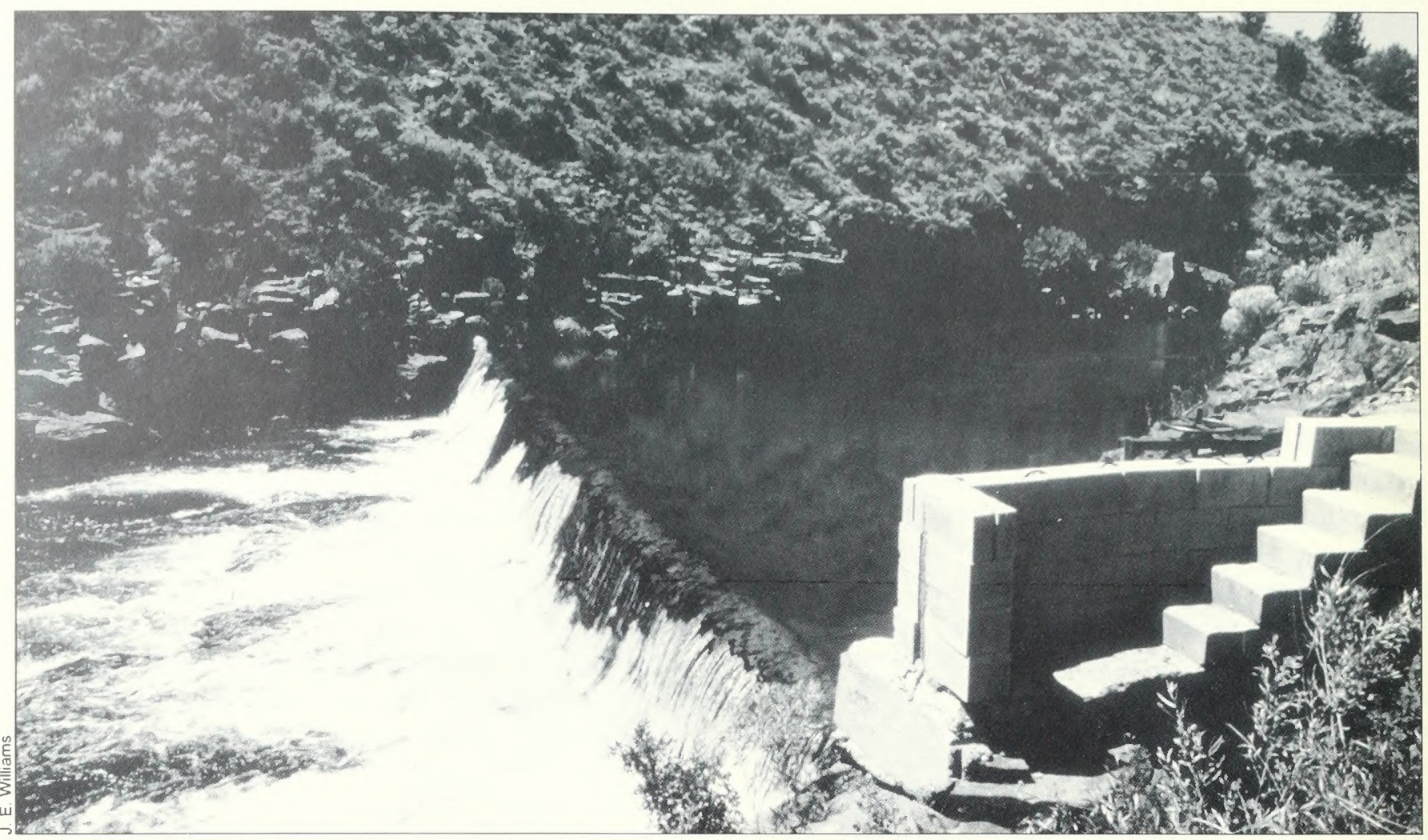

Water diversions decrease instream flows and form barriers to fish movement. This irrigation diversion dam in Warner Valley, Oregon, blocks spawning runs of adult Warner suckers from lake habitats into upstream spawning grounds. Even if adults are able to bypass the structure during high flows, young fish may be diverted into fields, where they perish. The local form of redband trout also is unable to reach spawning areas during most flow conditions.

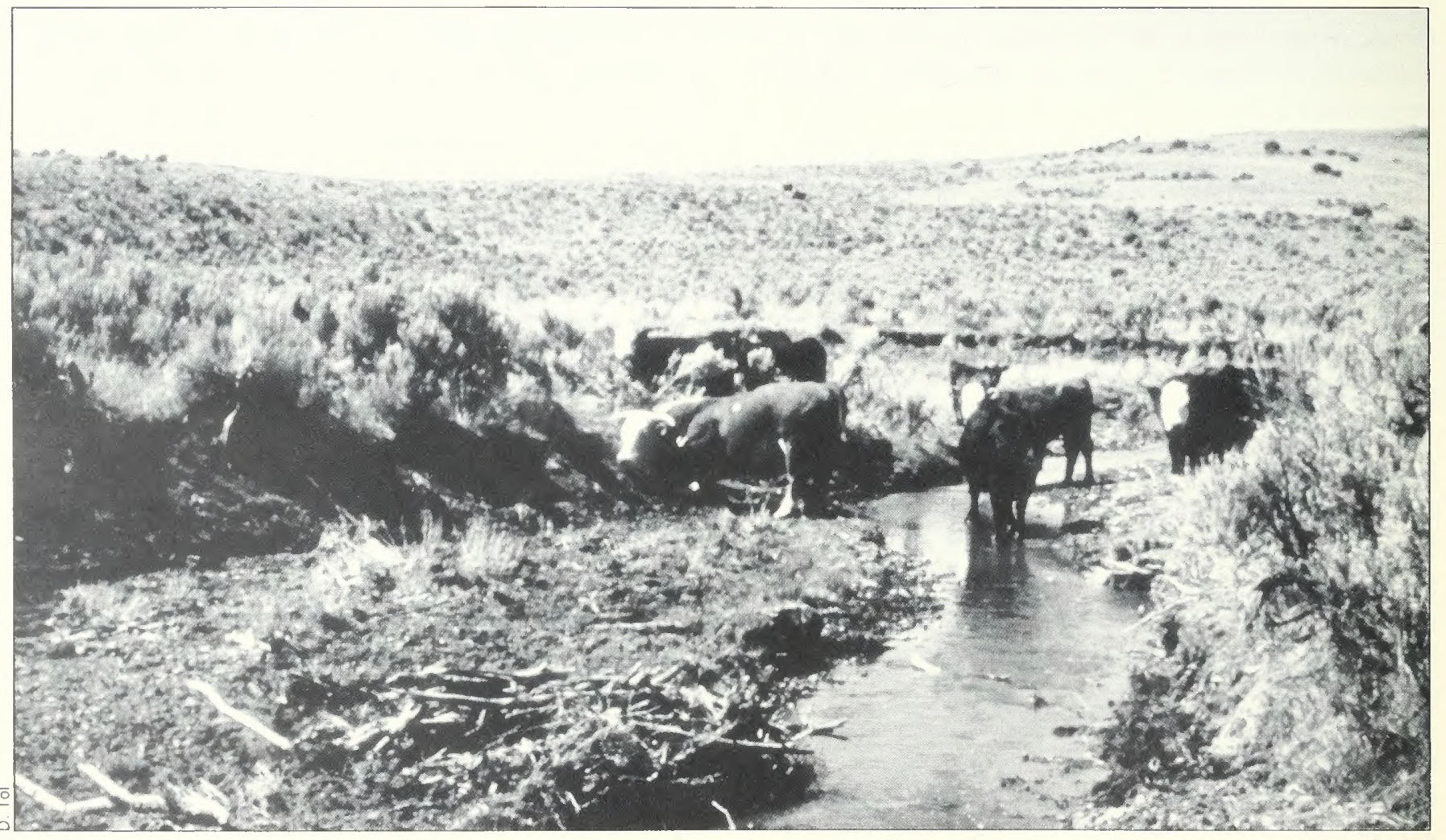

Impacts of livestock grazing on riparian areas are well documented. Soil compaction, increased turbidity, and toxic levels of ammonia and nitrites are problems in areas of heavy use. 
Livestock were grazed throughout the West and formed the basis of the economy in many of the drier areas where precipitation made farming difficult.

Early grazing was unrestricted, with sometimes fierce competition between livestock, humans, and wildlife for grasslands and water. Vegetation changes, loss of riparian areas, and channel degradation were common.

Widespread harvesting of timber supplied wood for a growing population as well as exports to timberpoor areas. While wagons and railroads were often used, the most common method of transporting timber was by water. Throughout the West, harvested trees were piled into streams, behind jams or splash dams, then floated out in large masses to a mill or shipment point. These large log masses severely damaged stream channels. Snagging, or the removal of imbedded logs to facilitate log floats, occurred throughout the West from the 1870's until well past the turn of the century.

While settlement of the West began in the mid1800 's, the rate of population growth began to increase markedly during the early 1900's, accelerating dramatically following World War II. Development of water for domestic and agricultural uses increased, and large dams were built to provide both the water and the power needed by the growing population.
Increased water use and changes in vegetation seriously stressed water supplies and aquatic ecosystems. Changes in runoff, reduced channel protection, and increasing erosion caused widespread channel degradation. Streamflows were altered, and removal of ground water caused streams and springs to dry up. Most aquatic systems were affected.

Habitat degradation caused the extinction of many known fish species and, in all probability, other unknown aquatic plant and animal species. A 1985 study of fishes in arid areas of the West by the Desert Fishes Council listed 182 fish taxa in North American deserts that warranted special management, with 46 of these classified as endangered. A 1989 study by the American Fisheries Society documented the extinction of 40 North American fishes, most of them from arid regions of the West (Miller et al. 1989).

Along the Pacific Coast, once abundant runs of anadromous salmonids have been dramatically reduced. While introductions of genetically inferior hatchery stocks have been a major factor, the construction of dams that changed free-flowing rivers into reservoirs and blocked the migration of fish has had the greatest impact. Today, many populations of salmon and steelhead trout have been lost or greatly reduced. Other species sharing the same habitat have

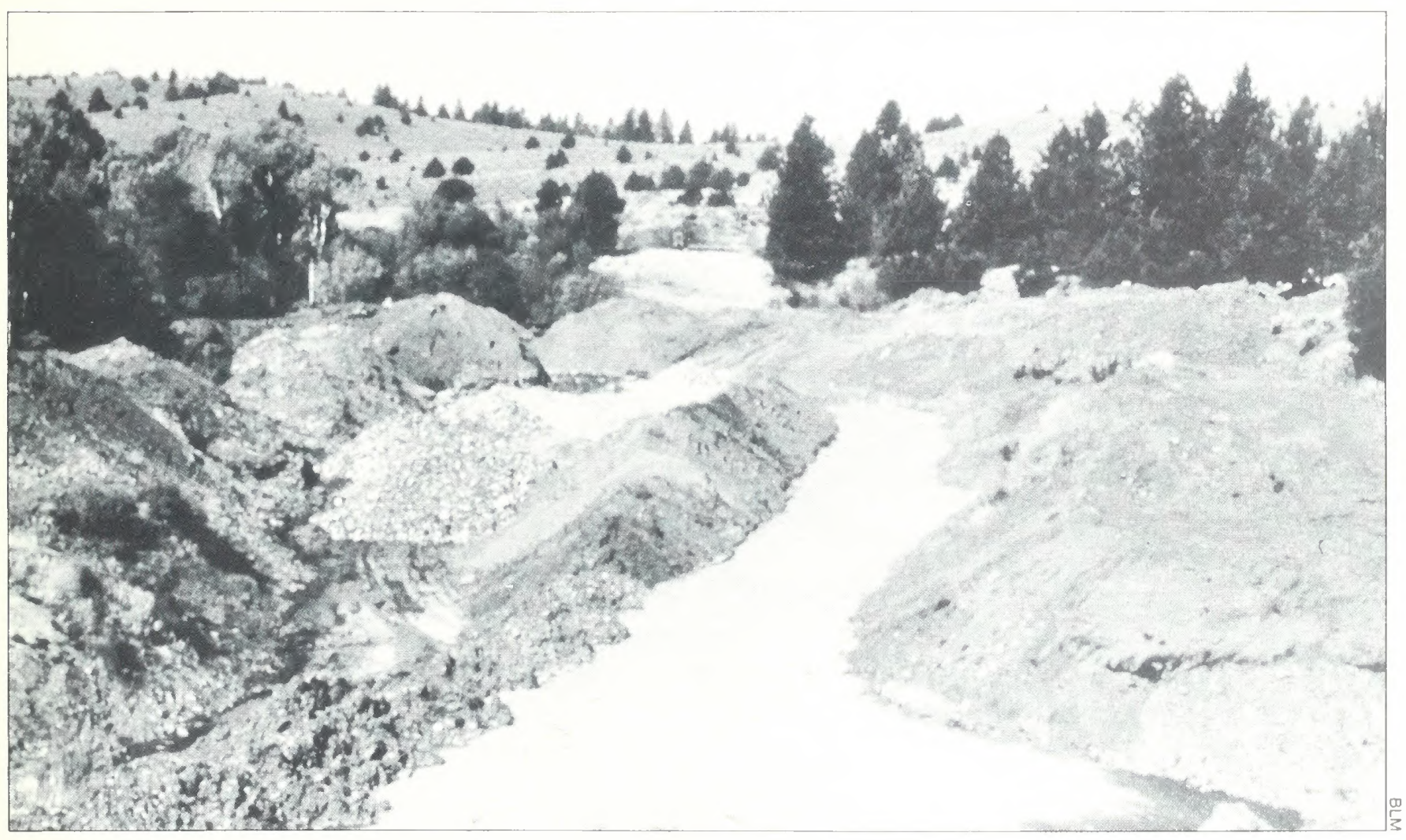

Mining activities have damaged numerous stream resources. Increased siltation, and occasionally, toxic levels of heavy metals contribute to decreased water quality. 


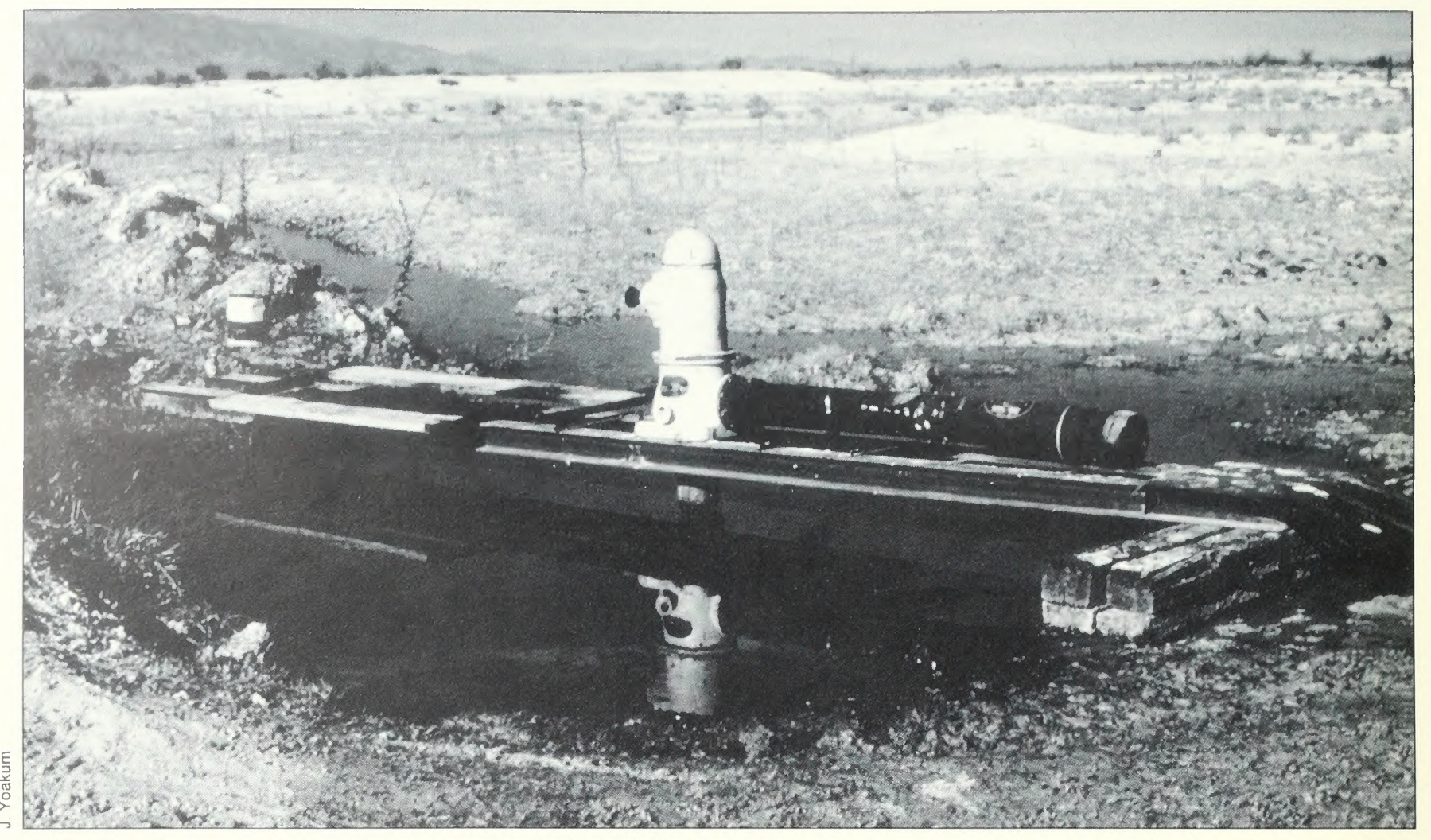

Pumping of spring resources and aquifers has decimated many fish habitats in the arid West. This photograph shows a pump suspended over Jackrabbit Spring in Ash Meadows, Nevada. Populations of endangered Ash Meadows pupfish and Ash Meadows speckled dace were destroyed by this activity.

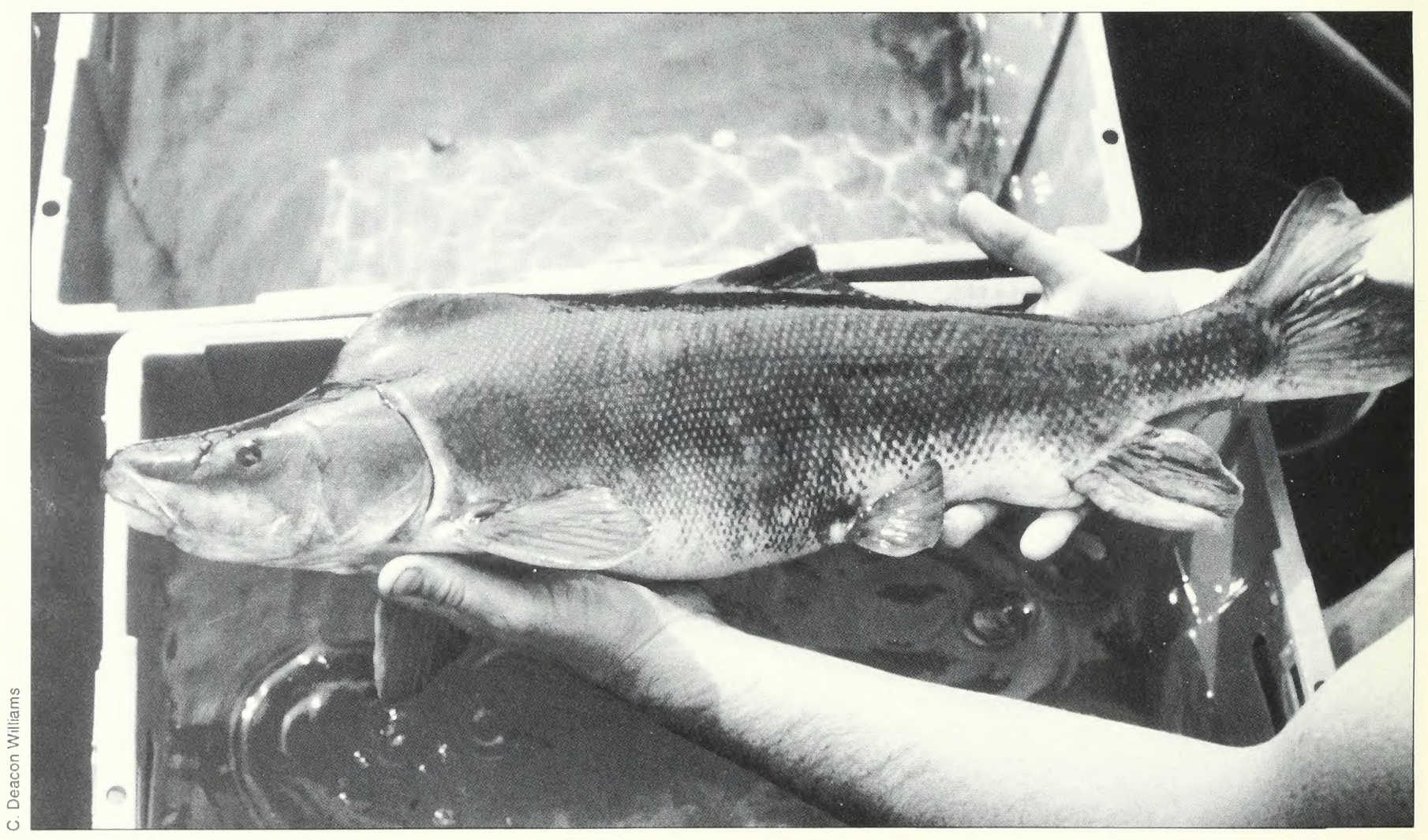

Razorback sucker. Only a few canyon areas of the Colorado River system still provide suitable habitat for native big-river fishes, such as the Colorado squawfish, humpback chub, bonytail chub, and razorback sucker. 
declined as well, a result of the habitat changes and competition from introduced species.

The introduction of nonnative species has contributed to the decline of native fish populations. Almost from the time settlement began, nonnative fish species were introduced for sport fishing, as a source of food, or by people looking for a place to dump fish they no longer wanted. Alteration of habitat, particularly the creation of large reservoirs, provided an environment where the introduced fishes could flourish.

For example, the Colorado River, which once flowed unimpeded from its headwaters in the Rocky Mountains through the canyons of the Colorado Plateau to the Gulf of California, is now dotted with dams. The native fishes are now restricted to reservoirs or the clear tailwaters below dams instead of the rapidly flowing, often turbid waters in which they evolved. The reservoir impounded by Davis Dam on the Colorado River, for example, harbors the largest remaining population of razorback sucker (Xyrauchen texanus) in the lower river basin. But it also contains 23 nonnative fishes, many of which are large predatory species. Studies at Arizona State University recently showed that most of the surviving razorback suckers in the reservoir are 24 to 44 years old and that virtually all young are eaten by predators soon after hatching.

Of 20 fishes native to California deserts, 7 are now extinct, 6 are endangered, and only 7 are not presently considered endangered or threatened. Besides habitat loss and alteration, surviving native fishes are forced to compete with more than 50 introduced species, many of them better adapted to new, artificial habitats.
Native trouts, such as the cutthroat trout (Oncorhynchus clarki), redband trout (O. mykiss), and bull trout (Salvelinus confluentus) were once widespread in major drainages and isolated areas throughout the West. Adapted to local conditions, they often survived in habitat considered marginal for salmonids. Changes in habitat and loss of water led to a decline in populations. Fish stocking programs of various agencies introduced hatchery trout that were not adapted to harsher environments. These introduced fish often interbred with the native fishes, leading to the extinction of many subspecies and populations. Eight cutthroat trout subspecies, for example, are listed as threatened or endangered, or are considered as candidates for listing.

At one time, Lahontan cutthroat trout (O.C. henshawi) occupied approximately 3,790 miles of streams and 333,585 acres of lake habitats in Nevada, California, and Oregon. Surveys completed in the late 1970's and early 1980's documented Lahontan cutthroat trout in only 304 miles of stream and 1,295 acres of lakes. Many of these populations were restricted to the headwater reaches of streams because of habitat degradation, along with or as well as hybridization and competition from nonnative species. lrigation, mining, logging, introduction of nonnative and exotic species, and livestock grazing all contributed to the loss of this subspecies from most of its habitat.

The circumstances are similar for Lahontan cutthroat trout habitat managed by the Bureau of Land Management. More recent surveys document only

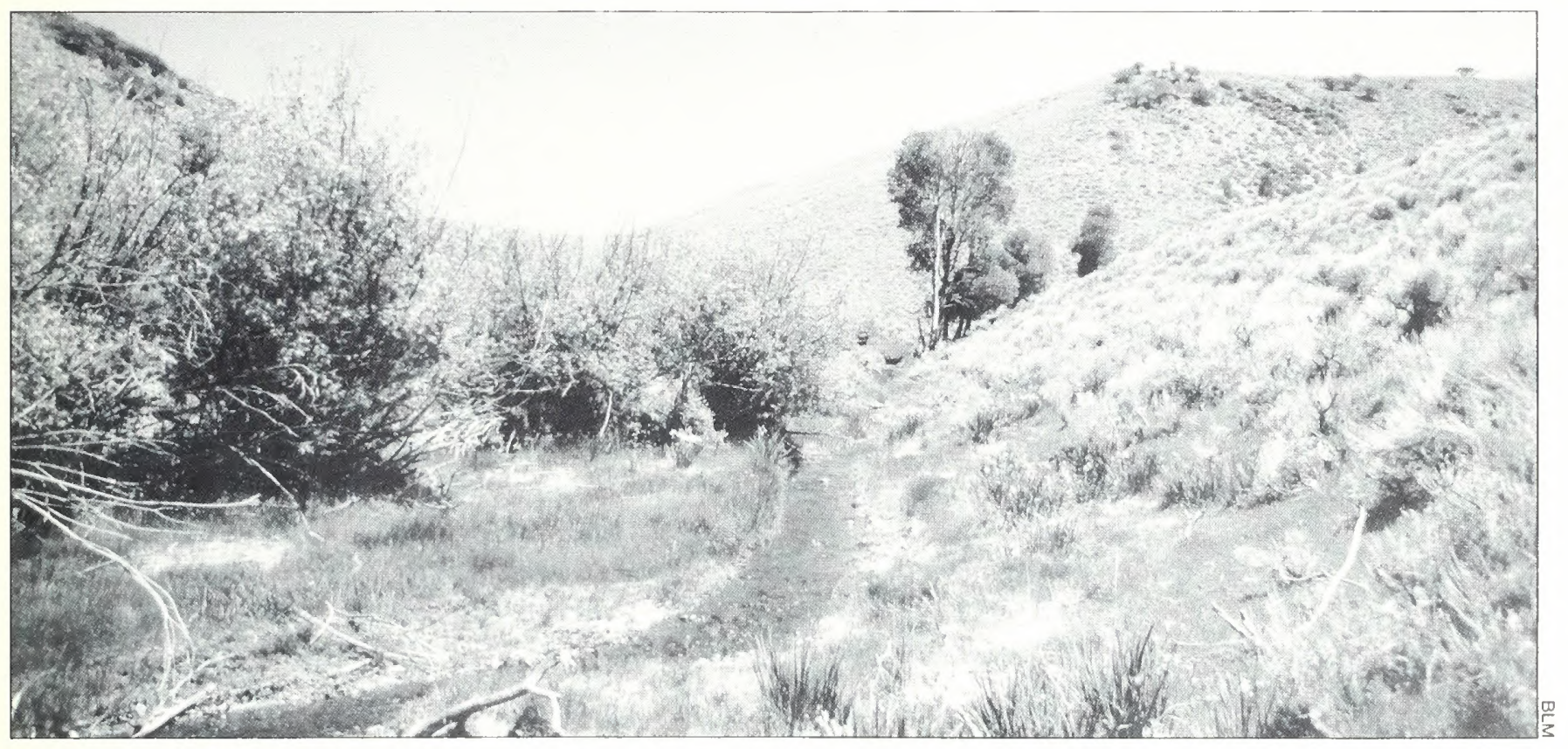

Mahogany Creek, Nevada. This Great Basin stream system provides refuge for a genetically-pure population of Lahontan cutthroat trout. 


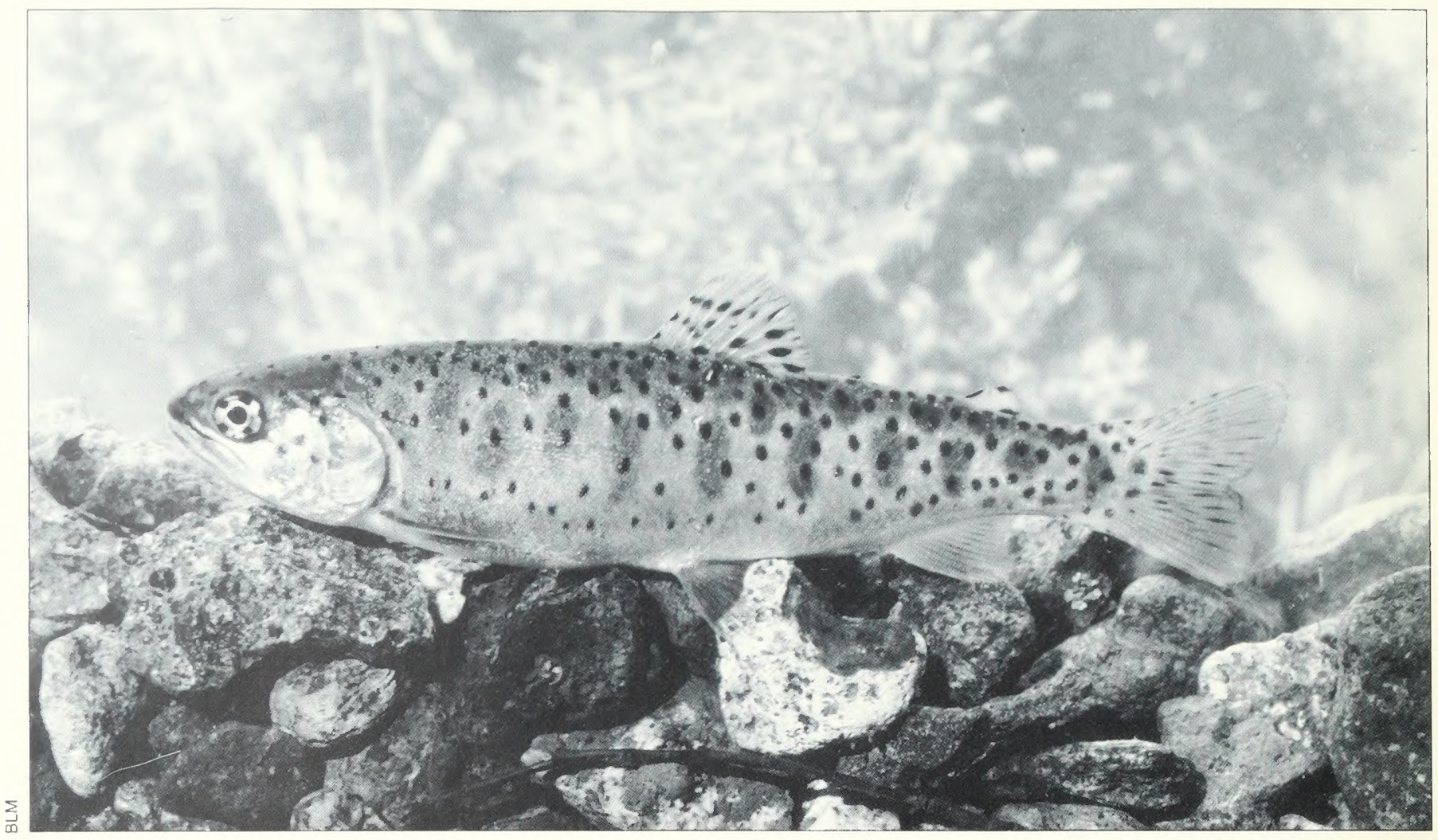

Humboldt form of Lahontan cutthroat trout. This fish is native to streams of the Humboldt River system of northern Nevada. Many ichthyologists believe the Humboldt form should be recognized as a separate and new subspecies of cutthroat trout.

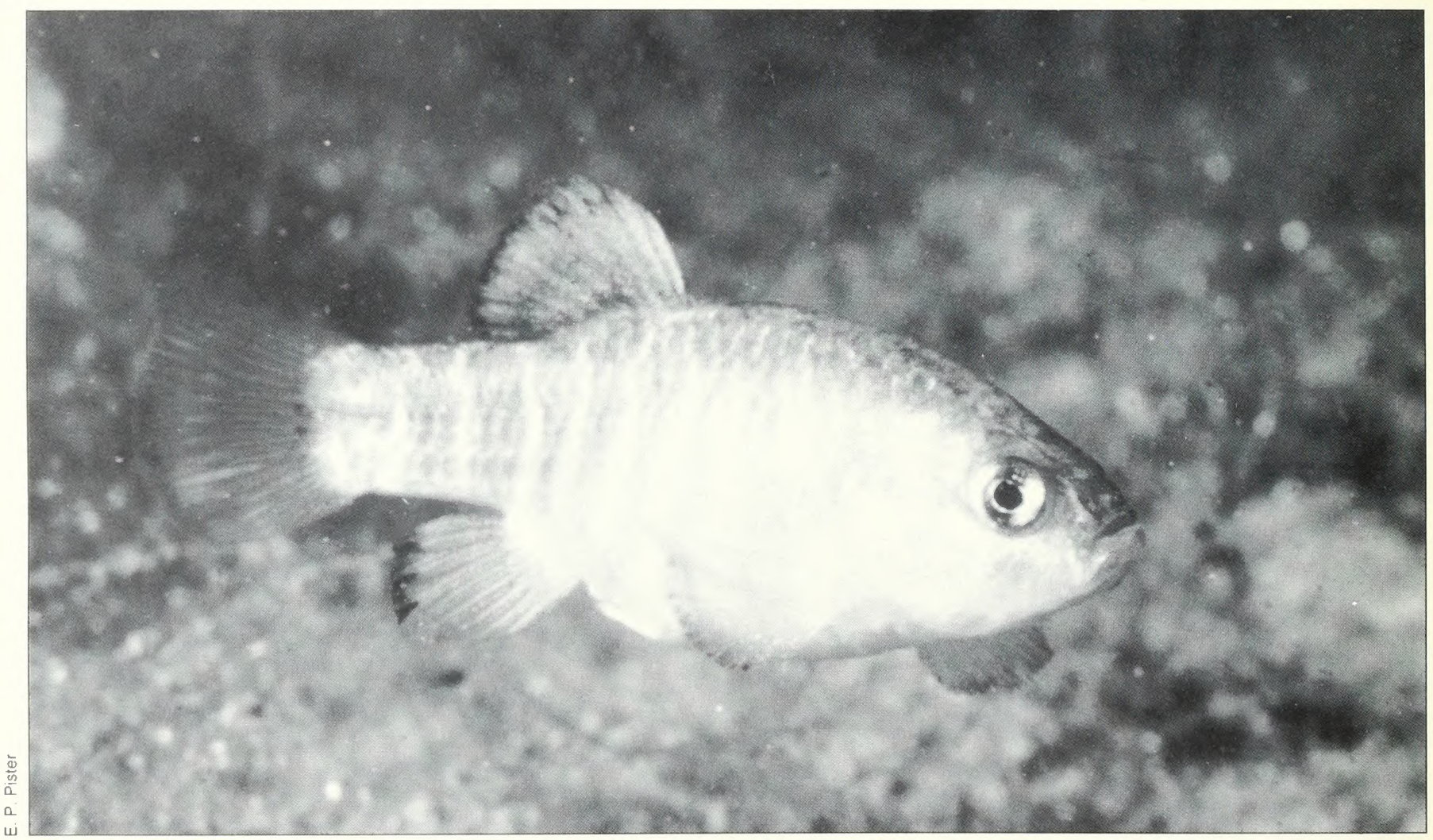

Numerous species of pupfishes occur on public lands: Owens pupfish (California), Amargosa pupfish (California), Ash Meadows pupfish (Nevada), warm spring pupfish (Nevada), Pecos pupfish (New Mexico), and desert pupfish (California and Arizona). 
233 miles of stream still occupied by Lahontan cutthroat trout and the closely related Whitehorse cutthroat trout (O. c. ssp.), out of approximately 1,713 miles of historic stream habitat on public lands. The primary cause of this habitat decline was the loss of riparian vegetation and the destabilization of streambanks by concentrated livestock grazing along stream courses. This was complicated by floods and a recent drought throughout the Lahontan Basin. Surveys indicate that management of 75 to 85 percent of occupied and historic habitat on public lands needs to be improved in order to recover the Lahontan cutthroat trout.

\section{Early Management Efforts}

Concern for better management of public rangelands prompted passage of the Taylor Grazing Act in 1934. The purposes of the Act were to "stop injury to the public grazing lands by preventing overgrazing and soil deterioration; [and] to provide for their orderly use, improvement, and development..." The Act authorized the Government to manage the public rangelands rather than simply dispose of them to other parties. In 1946, BLM was created by reorganizing and combining the General Land Office and the U.S. Grazing Service. These actions provided the foundation for positive management of aquatic resources on public lands.
By the 1960 's, biologists were hired by BLM and efforts were begun to preserve aquatic systems and native fish species. One of the first refuges for a native species was the School Springs Refugium in Ash Meadows, Nevada, constructed by BLM in 1970 to save the endangered Warm Springs pupfish (Cyprinodon mevadensis pectoralis).

BLM biologists and managers were part of a growing effort by many agencies and individuals to protect biological diversity and endemism of aquatic species in arid lands. Early preservation activities resulted in the formation in 1968 of the Desert Fishes Council, an interdisciplinary and international organization that is dedicated to the protection of desert fishes and their habitats. Similar cooperative efforts occurred in other parts of the country, often informally, through professional organizations such as the American Fisheries Society, Trout Unlimited, or local interest organizations.

Early management efforts were sometimes desperate attempts to provide last-second reprieves, saving some fish from extinction. The last remaining Owens pupfish (Cyprinodon radiosus) were rescued from a drying pool only hours before they would have become extinct. The Pahrump poolfish (Empetrichthys latos latos) survived in a horse trough until a more stable habitat was found at Shoshone Ponds on public lands.

Passage of the National Environmental Policy Act (NEPA) in 1969 and the Endangered Species Act (ESA) in 1973 bolstered efforts to preserve aquatic

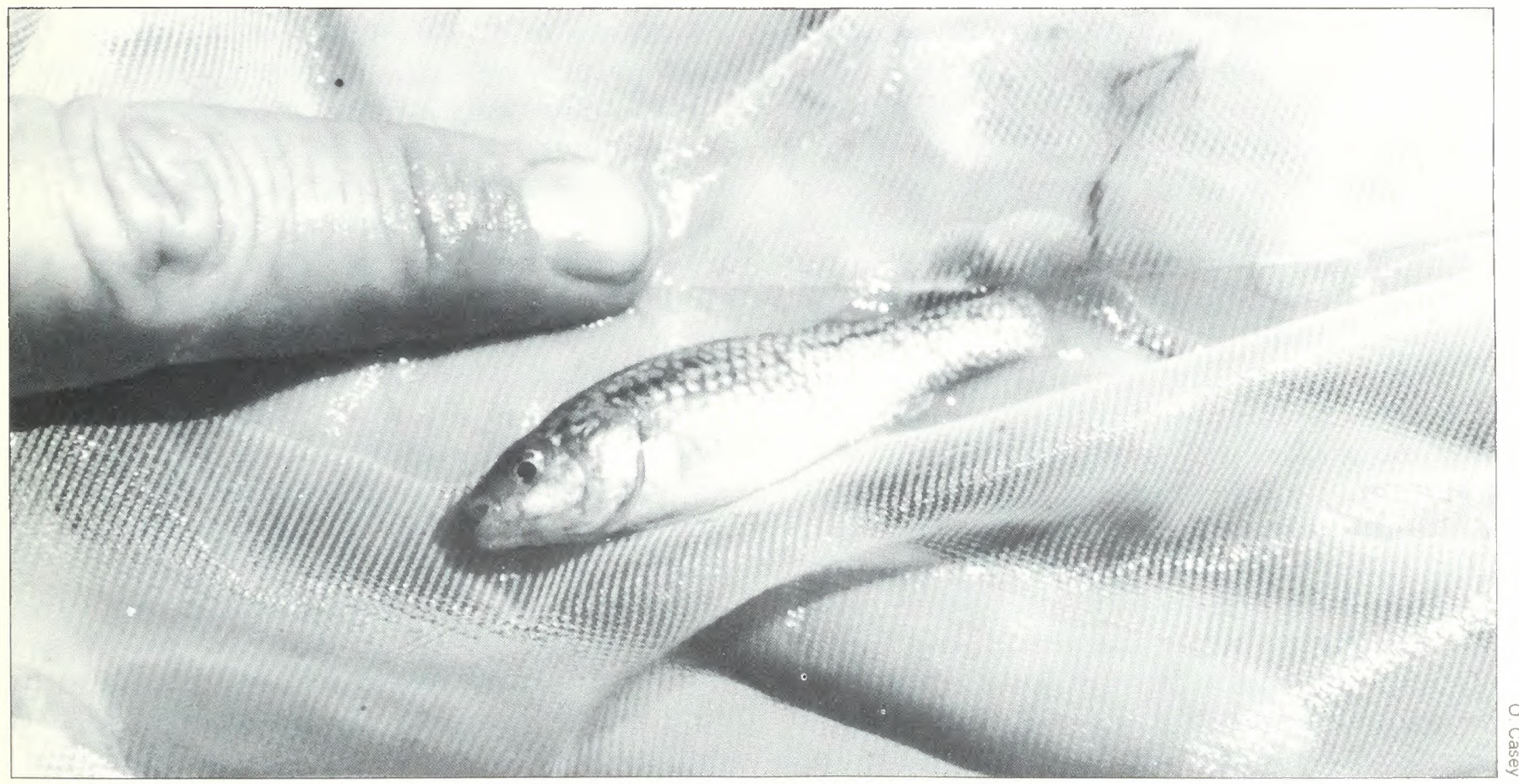

Pahrump poolfish. This fish was endemic to a single spring pool at Manse Ranch, Nevada. Its habitat was destroyed, but not before a small stock of this species was saved and translocated. 
ecosystems and native fish species. The Endangered Species Act provided, for the first time, a legal mandate for preserving native species. The Act was tested by efforts to save the Devils Hole pupfish (Cyprinodon diabolis) and its only home, Devils Hole, in Ash Meadows, Nevada. The actions resulted in a lawsuit that went all the way to the Supreme Court, with the Court ruling unanimously to uphold the Act and preserve the pupfish.

Efforts to protect native species and their habitats on public lands were aided by the passage in 1976 of the Federal Land Policy and Management Act (FLPMA) that codified BLM's direction to develop land use plans that included provisions for managing aquatic resources. While early BLM efforts were largely ad hoc, the passage of FLPMA, together with NEPA and ESA, provided a broad legal mandate for managing aquatic habitats and native species.

\section{Current Management Actions}

The task of managing special status fishes on public lands is immense. Although many of these fishes are locally endemic, others are far more wideranging and present special problems. Subspecies of cutthroat trout and big river fishes of the Colorado system range over many BLM jurisdictions and exemplify management complexity. While special status fishes are found in all states with extensive public lands except Alaska, the majority of species have their own unique characteristics and special management needs. Current management activities can be summarized into the following four general categories.

\section{Planning}

Basic decisions on land management, including aquatic resource management, are made principally through Resource Management Plans (RMPs). The RMPs are written by District or Resource Area staffs for all resources within the planning unit, describing how each resource is to be managed and the anticipated effects of this and other such management. Public participation is an integral part of all planning processes. In the RMP, the basic aquatic resources are identified and general management objectives are outlined.

More site or resource specific plans are called activity plans. For example, livestock grazing activities are governed by Allotment Management Plans (AMPs), which describe numbers and timing of livestock use, any improvements needed to support livestock use, and any constraints which may be placed on use. Timber plans are similar plans, developed for producing and harvesting trees, as well as providing information on reforestation of harvested sites. Site-specific plans for fish and wildlife are called Habitat Management Plans (HMPs), which are written for a specific geographic or habitat area. They include descriptions of habitat and species, the specific actions to be taken, and the expected outcome of management efforts. While site-specific plans usually emphasize one resource, they incorporate interrelationships with other resources.

Because of the Bureau's move toward Automation, Information Resource Management, and Modernization (AIM), several data bases were eitlier developed or are under development that will enable BLM to store, retrieve, and analyze rare fish data. These data bases are fully documented in the strategy plan for the Wildlife and Fisheries Information System that is currently being reviewed for final publication.

Managing special status species habitat also may be included in management plans for Areas of Critical Environmental Concern (ACECs). These are areas of usually limited geographical scope that have natural values requiring specialized management, such as fragile geologic formations, unusual vegetation types, or sensitive fish or wildlife. After ACECs are identified, management plans are developed much like other activity plans. BLM also participates in recovery plans for management of Federally listed threatened and endangered species and their designated critical habitats. Needs of listed species are identified in recovery plans, or through formal consultation with the Fish and Wildlife Service, are incorporated into other activity and land use plans, and may be the basis for a formal ACEC designation or habitat management plan. The following examples demonstrate how the requirements of special status species and their habitats are incorporated into planning documents.

The Phoenix District RMP incorporated recovery needs and habitat management plan goals for Gila topminnows (Poeciliopsis occidentalis) and desert pupfish (Cyprinodon macularius) into its various 


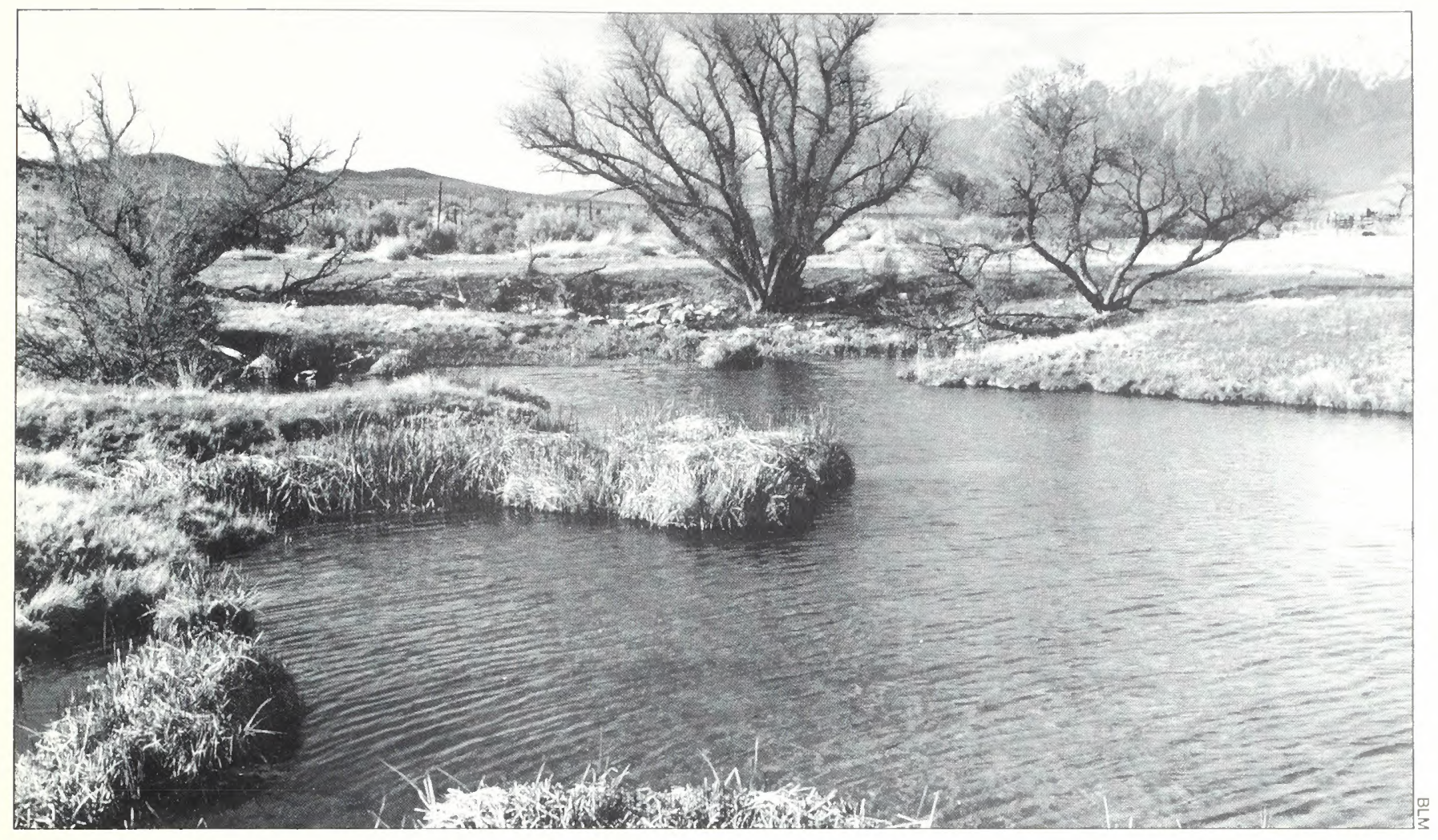

Fish Slough, California. This spring and marsh complex provide habitat for two endangered fishes, the Owens pupfish and Owens tui chub.

management alternatives. The final plan ensures recovery actions that are compatible with other management actions outlined in the RMP. These actions will be carried out through activity plans and on-the-ground actions.

Fish Slough, located in California's Inyo and Mono Counties, comprises a remnant of a once widespread, shallow aquatic/riparian wetland in the arid Owens Valley. Lying in the rain shadow of the nearby Sierra Nevada mountains, the Slough's northwest springs are the type locality for the endangered Owens pupfish. In addition, Fish Slough supports the Owens tui chub (Gila bicolor snyderi) and other rare fish, plant, and animal species, and represents the last portion of the Owens Valley floor that is essentially unaffected by human influence.

The 35,926 acres in and around Fish Slough are now designated as an $\mathrm{ACEC}$ and are managed under a joint agreement among BLM, California Department of Fish and Game, Fish and Wildlife Service, Los Angeles Department of Water and Power, and the University of California, which is considering portions of the Slough for the University's Natural Reserve System. Although multiple-use management occurs in most of the Slough, preservation and research considerations are paramount.

\section{Habitat Restoration, Protection, and Acquisition}

Few aquatic habitats remain unaltered. Fishes that evolved in one habitat can become stressed, and their populations reduced or even extirpated if their habitat changes. These changes can include reductions in flow, changes in channel characteristics, barriers to movements, or changes in water quality. A variety of techniques are used to restore habitats, with specific activities selected according to habitat needs. Habitat restoration is not limited to the immediate water body, but could include upslope or upstream areas as well.

Common restoration techniques include channel reconstruction, including modifying banks, or strategically placing structural materials such as rocks, logs, or brush. Vegetation can be manipulated by changing the management of riparian and upslope areas, as well as planting or removing selected species.

Prior to any restoration, specific objectives must be developed through an RMP, amendments, or other planning documents. The objectives also provide a basis for protecting areas once suitable conditions are attained. Long-term protection and maintenance of 


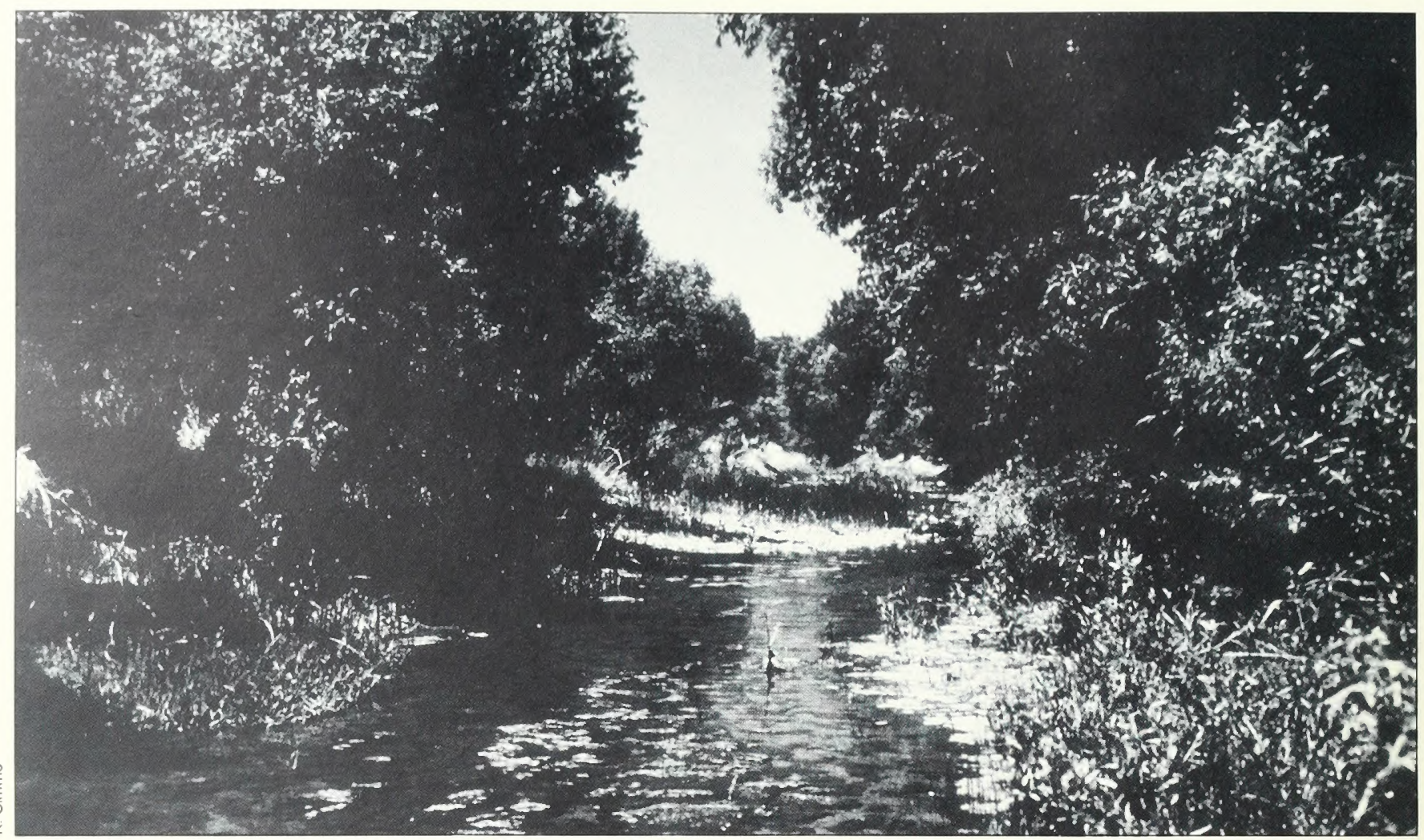

Cienega Creek, Arizona. Habitat acquired in 1988 protects a large population of endangered Gila topminnows.

aquatic systems require effective management, ranging from full protection to utilizing a variety of resources consistent with maintaining the aquatic system. Effective management is enhanced by the establishment of clear objectives.

The most effective management involves the entire watershed rather than just the limits of an aquatic habitat. While having only part of a watershed under a management plan can produce benefits for the aquatic system, full benefits will be obtained only when extended to the associated watershed. Techniques such as coordinated resource management plans or easements can be used in lieu of a full transfer of ownership as long as the long-term needs of the watershed can be met.

Land exchanges and acquisitions provide numerous opportunities for protection of rare fish habitats. An example is the Foskett speckled dace (Rhinichthys osculus ssp.), which is endemic to Foskett Spring in Coleman Valley of south-central Oregon. After consultation with the Fish and Wildlife Service in 1986, BLM acquired Foskett Spring and 160 acres surrounding the spring through a land exchange. The BLM fenced the parcel to exclude cattle and continues to monitor recovery of the habitat and vegetation growth.

The BLM completed a land exchange in 1986 for a major portion of the San Pedro River in southeastern
Arizona. BLM acquired the land to protect an important and unique southwestern riparian resource. The river no longer supports special status fishes, but BLM is working with the Arizona Game and Fish Department and Fish and Wildlife Service to determine which native species are suitable for restocking.

BLM completed another exchange in 1988 for the Empire, Cienega, and Rose Tree ranches in southeastern Arizona. Among other resource values, the lands were acquired to protect native populations of endangered Gila topminnows (Poeciliopsis o. occidentalis) and candidate Gila chubs (Gila intermedia) along 7 miles of Cienega Creek. BLM is now working on a plan amendment targeting protection, enhancement, and compatible recreation activities in the riparian zone.

When the Warner sucker (Catostomus warnerensis) was listed as a threatened species in 1985, critical habitat was designated along four streams in Warner Valley, Oregon. The habitat comprises a mixture of private lands and public lands administered by BLM. To restore degraded riparian habitats along these streams, BLM excluded livestock from 17.7 stream miles of critical habitat or streams tributary to the designated critical habitat stream. Reduced erosion and increased riparian communities not only benefitted the Warner sucker, but also improved habitat for redband trout, a candidate species. 


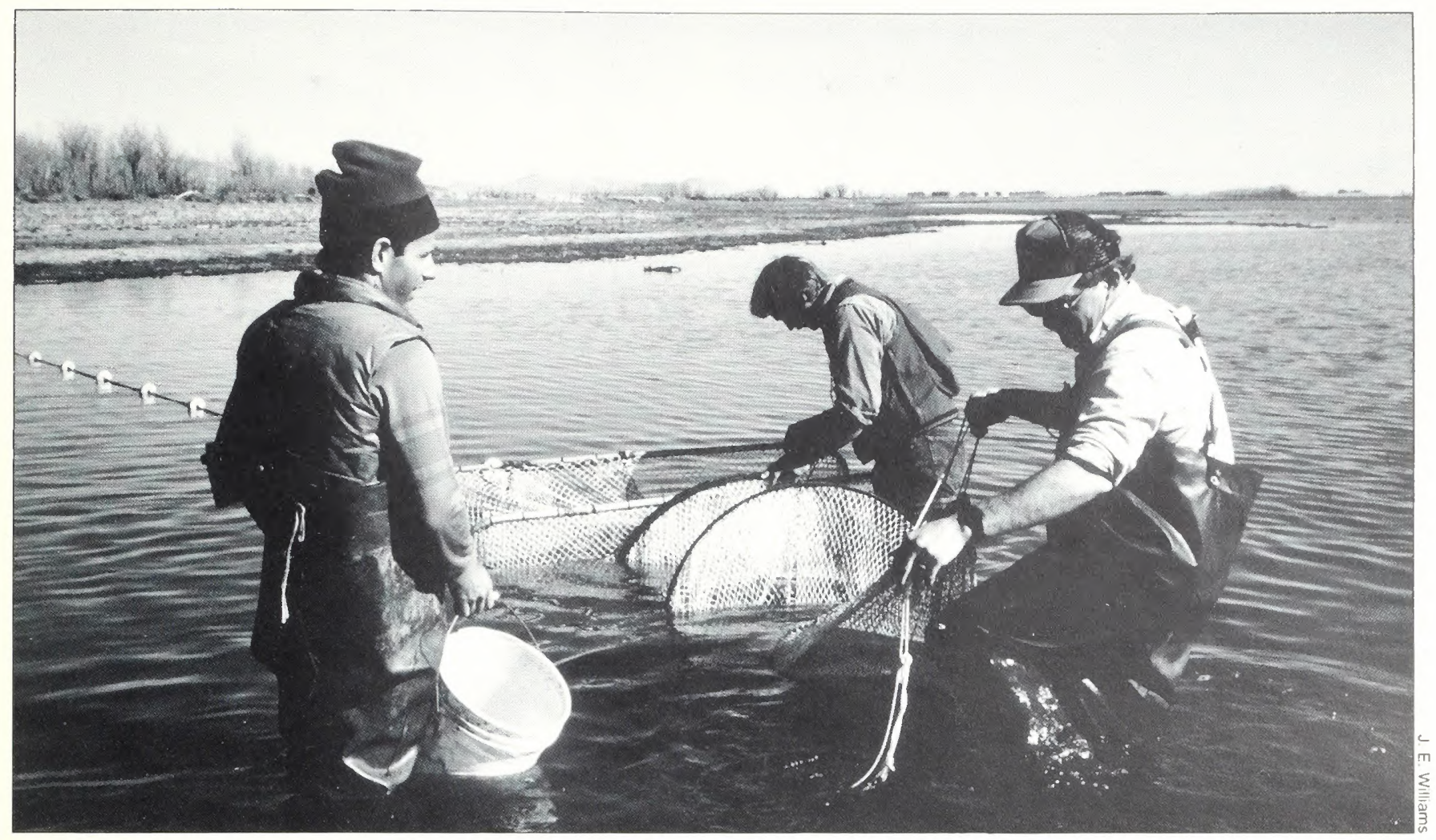

Hart Lake, Oregon. A cooperative study by The Nature Conservancy, Oregon Department of Fish and Wildlife, Fish and Wildlife Service, and BLM is designed to monitor the threatened Warner sucker and determine its interactions with introduced white crappie.

In 1988, Land and Water Conservation Fund monies were appropriated for acquisition of wetlands in Warner Valley, Oregon. In 1989, 5,089 acres were acquired and the Warner Lakes ACEC was designated. Although the primary stimulus for these actions was protection of wetlands, the threatened Warner sucker will benefit because of its presence in the potholes area. The acquisition also includes limited water rights for Honey Creek, which supports the primary remaining spawning habitat for the sucker.

\section{Water Rights and Water Quality Protection}

Water is required to provide habitats for aquatic species. Because of the growing demand for water, maintaining sufficient habitat for special status aquatic species is a major challenge. Many states now recognize instream water rights for fish, but these rights may be insufficient or secondary to other rights. Another problem has been the decline in ground water as a result of pumping, which has resulted in a lower water table and drying of streams and springs. Many basins in arid areas have underground water supplies that are recharged at slow rates. Water can be removed much faster than aquifers can recharge, eventually exhausting ground water supplies and leaving no surface water for fish, and perhaps not enough water to maintain farming or other activities.

Acquisition of water rights can be an important step in securing habitat for sensitive species. The water rights can be secured by BLM through procedural requirements of various State laws and regulations, or developed through State programs of reserved water rights for fish. Acquisition of water rights, particularly senior water rights, may be a more stable long-term solution. However, if aquifers and flows in basins are not managed by State agencies in a manner that secures long-term water supplies, possession of water rights may be no guarantee of species survival. Close coordination is needed with appropriate State agencies and other users to ensure adequate water supplies.

In 1980, BLM and Fish and Wildhife Service, for example, worked together on instream flow studies of Burro and Aravaipa Creeks in Arizona. The study determined needs of aquatic resources, including two threatened and one candidate fish species. After completing the studies in 1983, BLM filed with the 
Arizona Department of Water Resources for instream flow water rights, which were granted in 1989.

BLM petitioned the Arizona Department of Health Services in 1984 to protect Burro Creek and Peoples Canyon Creek under the State Unique Waters Program. The Arizona Water Quality Control Council approved the designations in 1985. The designations raised water quality standards for these two creeks to the ambient high water quality, protecting them from degradation. Special status fishes that inhabit the two creeks will benefit from this designation.

\section{Relocating Special Status Fishes}

BLM has assisted State fish and wildlife agencies in maintaining sensitive species through development of refuges. While these may sometimes incorporate natural habitat, more frequently they involve moving species to new locations. Alteration of habitats, competition with nonnative species, and drying out of habitats may necessitate relocating fish to more secure areas.

In recent years, efforts have been made to artificially spawn special status species. Offspring of these species are then reintroduced into historical habitats. The Fish and Wildlife Service has developed the capability to maintain a number of species and to successfully propagate them. BLM has cooperated with the Service in stocking these into native habitats on public lands.

Public lands afford numerous opportunities to restore and recover endangered fishes by translocations. As an example, stocks of Foskett speckled dace were introduced in 1979 and 1980 by Oregon Department of Fish and Wildlife and BLM to a nearby spring on public land in Coleman Valley, Oregon. The introduced population was fenced to prevent cattle from grazing and fragile spring habitats from being trampled.

In 1982, BLM and the Arizona Game and Fish Department signed a Memorandum of Understanding on stocking nongame fishes onto BLM public lands in Arizona. In 1983, the two agencies stocked Mesquite Spring with desert pupfish. They released Gila topminnow into Tres Alamos Falls, Peoples Canyon, and Yerba Mansa Spring under full protection of the Endangered Species Act. BLM identified 37 more sites for stocking after the Fish and Wildlife Service listed populations as experimental, which limits protection under the Endangered Species Act. After the desert pupfish was listed as endangered in 1986, BLM prepared a revised and amended plan for intro- ducing endangered fishes, combining both Gila topminnow and desert pupfish stocking. In 1990, one site containing topminnows was stocked with pupfish; a second site will be stocked with their offspring.

Other refuges for rare fishes have been created recently on public lands. Often these have consisted of transplanting stocks of rare fishes from natural habitats to historically fishless springs and creeks. Examples of such refuges on public lands include Chimney Hot Springs in Nevada (established for the threatened Railroad Valley springfish, Crenichthys nevadae), Dace Spring in Oregon (established for the threatened Foskett speckled dace), Blue Link Spring in Nevada (established for the endangered Hiko springfish, Crenichthys baileyi grandis), and Yerba Mansa in Arizona (established for the endangered Gila topminnow).

Spawning fish in hatcheries and using refuges must be considered as extreme measures, to be used only when native habitats appear unable to support the species. Proper management of habitat to ensure survival in natural ecosystems remains the goal of the Endangered Species Act. Fish should only be relocated as a last resort, and within established guidelines (Conant 1988, Williams et al. 1988).

\section{Values of Improved Management}

\section{Biodiversity Values}

The Office of Technology Assessment defines biodiversity as the aggregate of species assemblages (communities), individual species, and genetic variation within species and the processes by which these components interact within and among themselves. Three levels of biodiversity are recognized: (1) community or landscape diversity (e.g., Central Valley riparian woodlands, riparian scrublands, and Sonoran riparian deciduous woodlands); (2) species diversity; and (3) genetic diversity within species (e.g., populations or subspecies within a species). It is clear that biodiversity does not simply mean species richness. Introductions of nonnative species usually result in decreased long-term stability of fish communities, which leads to eventual loss of diversity. This is especially true in aquatic communities, where introduced fishes often have numerous dispersal routes via creeks and rivers, and where exotic fishes often outcompete or prey on native fishes. 
The many valuable roles of intact ecosystems have only recently been realized. For example, watersheds on public lands provide most of the drinking water in western states. The value of undamaged watersheds in providing high-quality potable water is largely underestimated but will increase greatly with continued pollution of ground water supplies. The effects of natural catastrophes, such as floods and fires, are moderated when landscapes are diverse and habitats are not fragmented by overharvesting of timber supplies or overgrazing by livestock. For example, forested areas buffer wet meadows from the drying effects of summer winds. Riparian areas shade streams and thereby maintain cool water temperatures that support trout populations. Healthy riparian communities filter much of the silt-laden runoff belore it can reach streams. These buffering properties of stable communities will become even more critical with continuing global climate changes.

\section{Scientific Values}

Much scientific information is lost when a species or population is extirpated. Studies of pupfish in highly saline springs (some are up to nine times the salinity of seawater) have provided much information about kidney function in vertebrates. Many medicines are derived from obscure and seemingly useless plant species. On a broader scale, isolated populations and species are important in explaining zoogeographic patterns and speciation events. Electrophoretic study of the extinct Alvord cutthroat trout (Oncorhynchus clarki ssp.), for example, would have been invaluable in determining relationships among Lahontan cutthroat trout and the trout in Willow and Whitehorse Creeks. The study could have explained the direction and location of prehistoric stream capture and overflows among the now isolated basins of northern Nevada and southern Oregon.

Genetic differences between isolated populations of the same species can be substantial. Such variability is essential for adaptation to changing environmental conditions. Studies of isolated native fish populations in the Southwest have shown that large portions of the genetic variability within a single species are lost when only one population of a species is preserved. Genetic studies of southwestern fishes con- ducted by Oklahoma State University scientists demonstrated that protection of numerous populations from throughout the species' geographic range is necessary to preserve the large majority of genetic information contained by the species.

\section{Recreation Values}

Many special status fishes on public lands have valuable recreation potential. Isolated populations of redband trout occur in eastern Oregon, northern California, northern Nevada, and southwestern Idaho. These native trout are well-adapted to small, alkaline streams that are typical of the region. Recent studies have confirmed that redband trout populations in each isolated drainage basin are genetically and ecologically distinct from each other. If these distinct forms are successfully managed, anglers can enjoy opportunities to catch a variety of troul and to catch species with unusual color or spotting patterns.

Populations in some basins thrive in streams normally considered 100 warm to support trout. Others naturally occur in highly alkaline lakes. These populations have great potential for development of trophy trout fisheries on public rangelands.

Public lands in nearly every western state contain habitat for one or more subspecies of cutthroat trout. The Bonneville cutthroat trout (Oncorhynchus clarki utah), for example, ranged over a vast area of Idaho, Nevada, Utah, and Wyoming. Introductions of nomnative trout have been largely unsuccessful in the marginal streams historically occupied by the Bonneville cutthroat trout, but they survived long enough to hybridize with and destroy the native cutthroat populations. Most streams that once supported Bonneville cutthroat trout now are barren of any sportfish. Reintroduction of these fishes would substantially increase recreational fishing potential.

Many special status fishes also have potential for nonconsumptive recreation. More and more people are interested in viewing wildlife in natural settings. Many of these fishes, such as springfish and pupfish, live in small habitats where they are readily visible to visitors. Increased publicity and access to special status fish habitats can increase visitations to public lands and improve appreciation of this resource. 


\section{Strategy Plan}

Despite past management actions and practices, 20 fishes occurring on public lands have been listed as threatened or endangered pursuant to the Endangered Species Act during the past 10 years. Therefore, it is critical that BLM incorporate the needs of special status species into planning efforts and that areas of land sufficiently large to protect the contained aquifers and stream systems be conserved to save the fishes and other associated life forms for future generations.

While aquifer and stream protection within major land units may be considered "strategic" planning for fishes on public lands, many opportunities exist for "tactical" projects to strengthen stream habitat integrity by improving land management practices in more limited areas. Much of this will require reassessing past management strategies and aggressively managing special status species throughout BLM programs.

Unfortunately, the gap between protection provided by the Endangered Species Act and that needed to conserve the diversity of fishes has increased on public lands. Economically, it may be impossible to recover all rare fishes if conservation actions wait until the species are listed as endangered or threatened. Recovery plans for listed species typically describe recovery actions that cost hundreds of thousands of dollars or more. Management options on public Iands also may be limited if endangered or threatened species are present. If protection is extended to sensitive and candidate fishes, the need to list these species pursuant to the Endangered Species Act will be reduced, which clearly is to the public's benefit.

Good land and water management is the key to maintaining diversity of all species which, once lost, can never be recreated. Protection of these special status fishes and their habitats constitutes a positive step toward proper stewardship of public lands. It aIso enables the passing of an undiminished biota to future generations.

\section{Objectives}

To achieve the special status species goals in Fish and Wildlife 2000, the Special Status Fishes Team developed the following more specific objectives:

- Recover Federally listed fishes on public lands and the ecosystems on which they depend.
- Manage candidate, sensitive, and State-listed fishes on public lands and the ecosystems on which they depend to improve their status and to prevent the need for Federal listing.

A variety of laws, Executive Orders, and policy statements assist BLM in achieving these objectives. The foundation for the Bureau's policy concerning the management and protection of special status fishes is the Endangered Species Act, as reauthorized in 1988 This Act and Bureau Manual Section 6840 create a nondiscretionary and legally binding obligation for BLM to protect and recover threatened or endangered species and prevent the need for listing candidate and sensitive species.

Bureau Manual Section 6840, Special Status Species Management, provides detailed policy and guidance to BLM managers on the implementation of the Endangered Species Act. This policy declares BLM's intent to conserve special status species and the ecosystems upon which they depend. The basic elements are as follows:

- To inventory occurrence and distribution of sensitive species, identify essential habitats, and determine the significance of public lands in the conservation and recovery of these species.

- To create objectives and implement actions through management plans that will ensure the conservation and recovery of threatened and endangered species and their habitats.

- To ensure that no BLM action, or authorized action, jeopardizes the continued existence of any Federal or State-listed, proposed, or candidate species, or their habitats, nor jeopardizes the likelihood of recovery of any of these species.

- To ensure that the status of any species that is considered sensitive or candidate for listing does not decline so that listing becomes necessary.

- To consult with the Fish and Wildlife Service on any action that will adversely affect a threatened or endangered species and confer on any action which will adversely affect a species proposed for listing. 


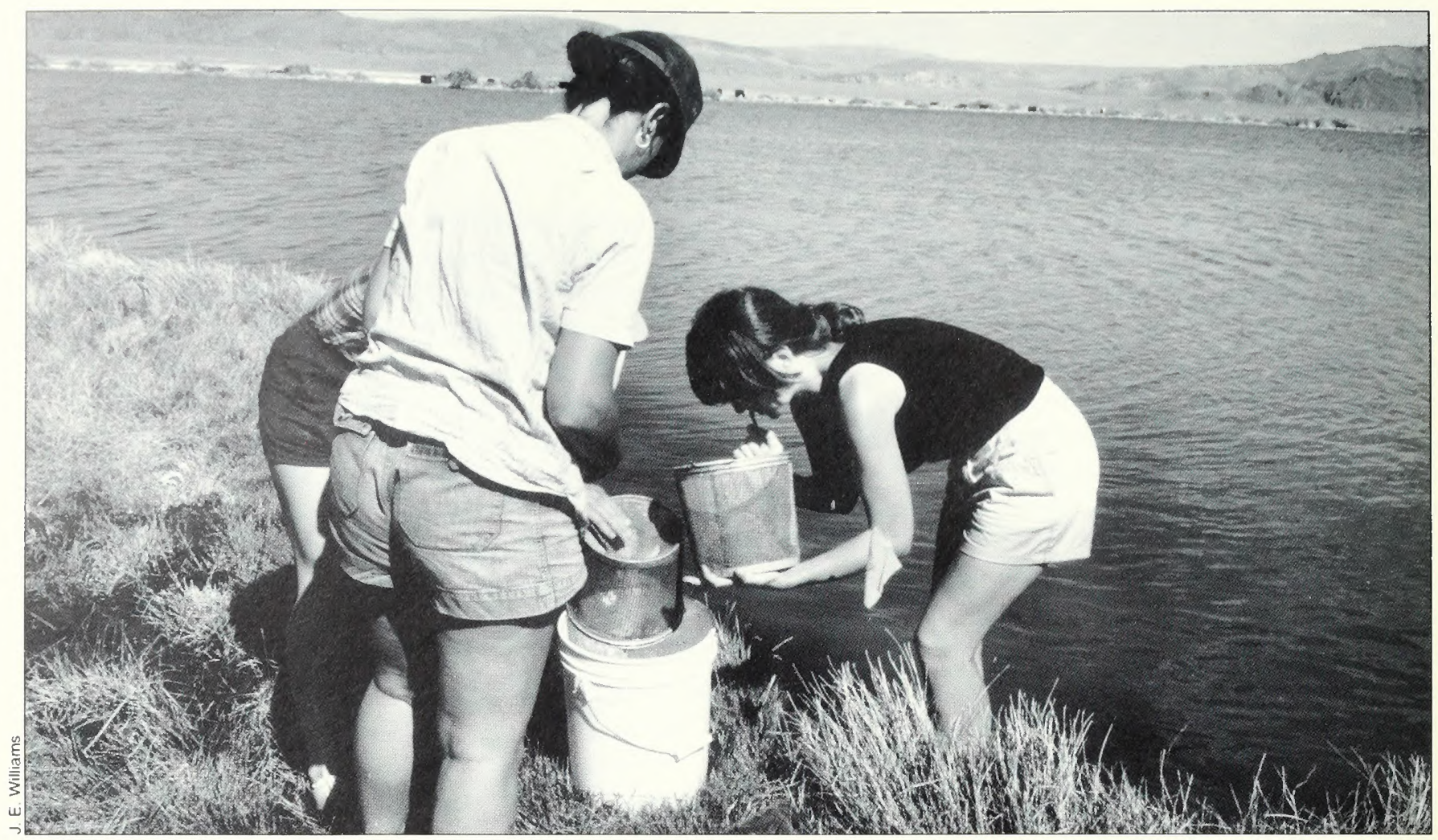

Borax Lake, Oregon. A cooperative study with The Nature Conservancy monitors population dynamics of the endangered Borax Lake chub.

\section{Strategies}

\section{Strategy 1: Inventory}

- Determine the occurrence, distribution, and condition of special status fishes on lands administered by BLM.

- Identify lands administered by BLM that are critical, essential, historical, or potential habitat for special status fishes.

\section{Strategy 2: Planning}

- Incorporate measures to protect special status fishes and their habitats in RMPs and sitespecific activity plans.

- Incorporate measures identified in this plan to protect special status fishes into State Fish and Wildlife 2000 documents.

- Participate in the development and implementation of recovery plans for special status fishes.

\section{Strategy 3: Research}

- Participate in and support cooperative studies and research on genetic uniqueness of populations, reintroduction of fishes into historic habitats, habitat requirements, restoration techniques, and habitat ecology of special status fishes.

\section{Strategy 4: Habitat Protection}

- Utilize land exchanges, Land and Water Conservation Fund acquisitions, cooperative agreements, etc., to ensure protection of special status fishes.

- Retain in Federal stewardship all habitats essential for the survival or recovery of special status fishes.

- Secure water rights for special status fishes on public lands in accordance with State procedures and regulations. 
- Ensure adequate water quality for special status fishes through the Clean Water Act or other relevant State legislation.

\section{Strategy 5: Coordination}

- Encourage close working relationships with all parties concerned with management of special status fishes.

\section{Strategy 6: Habitat Management}

- Maintain biodiversity and protect the genetic integrity of special status fish populations by constructing habitat improvements and controlling undesirable species.

- Increase protection of special status fishes by eliminating land use conflicts or by mitigating those conflicts that cannot be eliminated.

\section{Strategy 7: Monitoring}

- Monitor and evaluate ongoing and proposed management activities to ensure that objectives for special status fishes are being met.

- Monitor habitats to determine current status of special status fishes and presence of undesirable species.

\section{Strategy 8: Increase Awareness}

- Increase internal and public awareness of the significance of special status fishes and their unique ecosystems.

\section{Program Guidance}

This section describes the management actions and habitat improvements needed to implement the strategies. Estimates of work needed and costs were provided by Resource Area, District, and State personnel for work to be completed during fiscal years 19912000. These estimates include additional work that cannot be accomplished with present staff and funding.

This program guidance is designed to meet the established national policy of maintaining species and their habitats. Planning, inventory, research and studies, acquisitions, cooperative agreements, habitat improvements, and monitoring, are all steps to achieve the goals and objectives of this policy. Implementation will be through the BLM's planning and budgeting process, utilizing existing legal mandates. Because of the legal stature of species protected by the Endangered Species Act, BLM will need to coordinate more closely with other agencies, particularly the Fish and Wildlife Service, than with other BLM planning efforts.

\section{Action Item 1: Inventory}

BLM offices identified 5,749 stream miles, 4,694 lake and reservoir acres, and 299 springs and ponds on public lands that need to be inventoried. Information is lacking for most of these habitats. The workmonths and costs to fully inventory the available habitat are shown in Table 1.

Inventory information provides the foundation for land use and activity planning, monitoring, and habitat improvements. Data from inventories provide the

Table 1. Inventories needed from fiscal years 1991 through 2000 for special status fishes on public lands.

\begin{tabular}{|c|rrrrr|}
\hline \multirow{2}{*}{ State } & Miles & Lake Acres & $\begin{array}{c}\text { Springs/ } \\
\text { Ponds }\end{array}$ & WM & $\$(000)$ \\
\hline AZ & 329 & 0 & 165 & 131 & 517 \\
\hline CA & 85 & 0 & 34 & 46 & 125 \\
\hline CO & 380 & 2 & 0 & 68 & 159 \\
\hline ID & 1,688 & 300 & 0 & 41 & 205 \\
\hline NT & 1,091 & 535 & 0 & 69 & 92 \\
\hline NV & 87 & 0 & 7 & 91 & 230 \\
\hline OR/WA & 554 & 449 & 25 & 60 & 347 \\
\hline UT & 276 & 0 & 63 & 587 & 210 \\
\hline WY & 810 & 0 & 0 & 299 & 224 \\
\hline \hline Total & 5,749 & 4,694 & & 59 \\
\hline
\end{tabular}


basis for management decisions on land use plans, discussion of impacts of management options, and development of sitespecific recommendations for activity plans. Baseline data are needed prior to initiating a monitoring program to gauge results of management activities.

\section{Action Item 2: Planning}

A total of 305 activity plans are needed for special status species and habitats

(Table 2). Development of activity plans through the land use planning process provides the most efficient and cost-effective way to achieve resource goals and objectives. The principal planning document for management of sensitive resources is the RMP, with site-specific activity plans then developed for implementing the RMP. Because of the interaction of the land base with the aquatic resources, interdisciplinary teams involving fisheries biologists and other resource specialists need to develop land use and activity plans to ensure adequate measures are taken to maintain and enhance the aquatic system.

Site-specific recommendations for aquatic habitat are made in fisheries habitat management plans.

Activity plans detail the objectives and specify management actions and habitat improvements needed to accomplish the plan objectives. While plans may be developed for individual sensitive species, the most efficient approach is to develop plans for specific habitats or basins, as maintenance of the habitat is necessary to maintain the species. Because one or more species of fish, plants, invertebrates, or other vertebrates can be associated with the same habitat, management actions for all these can be included within one activity plan.

\section{Action Item 3: Research}

Because of their limited numbers, distribution, and direct economic utilization, little is known about the life history of many special status
Table 3. Research and studies needed from fiscal years 1991 through 2000 for special status fishes on public lands.

\begin{tabular}{|c|rrr|}
\hline State & Studies & WM & $\$(\mathbf{0 0 0})$ \\
\hline AZ & 45 & 136 & 516 \\
\hline CA & 15 & 22 & 315 \\
\hline CO & 23 & 58 & 346 \\
\hline ID & 8 & 75 & 579 \\
\hline MT & 10 & 11 & 56 \\
\hline NM & 13 & 4 & 25 \\
\hline NV & 10 & 17 & 101 \\
\hline OR/WA & 16 & 27 & 144 \\
\hline UT & 11 & 40 & 55 \\
\hline WY & 2 & 40 & 100 \\
\hline \hline Total & 153 & 430 & 2,237 \\
\hline
\end{tabular}


by willing seller on the basis of purchase, exchange, easement, or donation. Costs shown in Table 4 largely reflect purchase prices, which would be reduced if sites were protected by exchange or donation.

Costs listed in Table 4 also include funds necessary to develop or maintain water flows for special status fishes. BLM field staff identified 196 sites where development of wells for springs and ponds, as

Table 4. Habitat acquisitions needed from fiscal years 1991 through 2000 to protect special status fishes on public lands.

\begin{tabular}{|c|rrrr|}
\hline State & Miles & Acres & WM & $\$(\mathbf{0 0 0})$ \\
\hline AZ & 80.0 & 16,470 & 44 & 11,057 \\
\hline CA & 43.2 & 12,800 & 61 & 5,541 \\
\hline CO & 37.5 & 3,120 & 51 & 853 \\
\hline ID & 80.5 & 16,700 & 41 & 1,291 \\
\hline MT & 16.0 & 1,000 & 34 & 147 \\
\hline NM & 7.0 & 2,400 & 10 & 1,500 \\
\hline NV & 29.9 & 4,852 & 32 & 10,172 \\
\hline OR & 20.1 & 1,700 & 100 & 3,277 \\
\hline UT & 32.3 & 2,595 & 56 & 434 \\
\hline WA & 0 & 0 & 0 & 0 \\
\hline WY & 14.0 & 17,000 & 17 & 60 \\
\hline \hline Total & 360.5 & 78,637 & 446 & 34,332 \\
\hline
\end{tabular}

Action Item 5: develop cooperative

Field offices should agreements with universities or groups such as the Desert Fishes Council or Trout Unlimited that have information and knowledgeable people that can aid in planning and managing special status species habitat. Lands administered by BLM often are intermingled with other Federal, State, and private lands. Forest Service lands often include headwaters

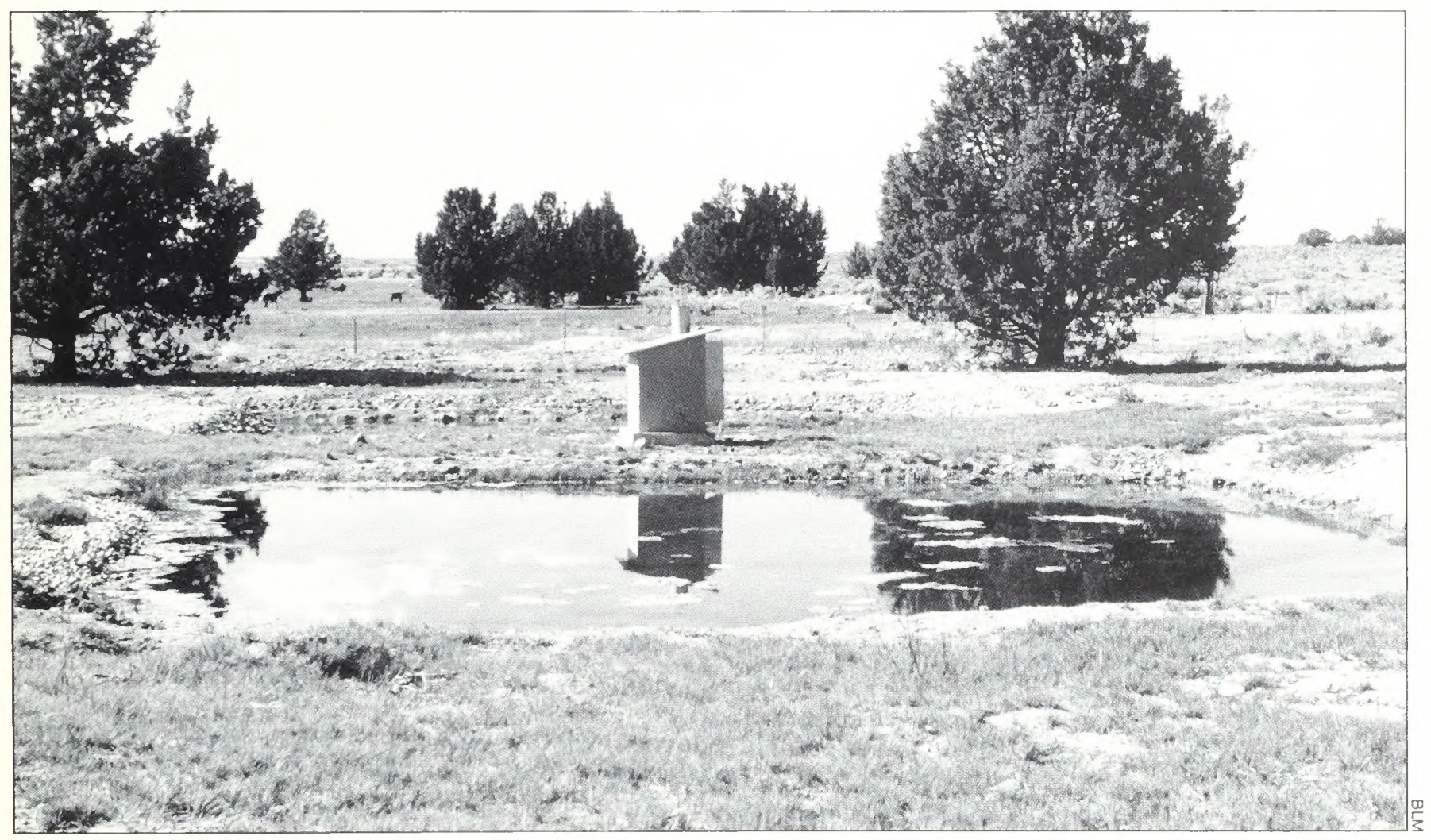

Shoshone Ponds, Nevada. These artificial ponds near Ely are utilized to harbor stocks of endangered fishes such as the Pahrump poolfish, whose natural habitats have been destroyed or severely modified. 
of streams that flow through public lands. To provide comprehensive and efficient management of watersheds, BLM should enter into cooperative agreements with other agencies, landowners, and interested groups. Because of the requirements of the Endangered Speeies Act, BLM must maintain a close working relationship with the Fish and Wildlife Service. In addition to developing its own activity plans, BLM must continue to participate in recovery plan actions for listed species, and work with other teams of State and Federal agencies, conservation organizations, and universities toward increasing understanding and awareness of sensitive species and their habitat needs. Trout Unlimited, for example, can provide volunteer and technical assistance for projects involving special stalus trout species.

For wide ranging special status fishes, management needs should be coordinated with affected public land users on a broad geographic basis, such as watershed or BLM District, rather than by each separate habitat. If management practices in more than one habitat of any BLM District are affected, then requirements for special status fishes should be coordinated with Multiple-Use Advisory Councils and Grazing Advisory Boards. An example is management of Lahontan cutthroat trout, which involves numerous streams in the Elko and Winnemucca Districts.

\section{Action Item 6: Habitat Management}

Implement 456 various habitat improvements needed to protect or enhance aquatic habitats for special status fishes on public lands (Table 5). In addition, several actions were identified for reducing conflicts from introduced exotic species; these actions include construction of fish barriers and removal of unwanted organisms. One or more actions may be recommended for a specific habitat improvement activity plan, and plans frequently address management of a number of springs, lakes, reservoirs, or streams. These actions will be coordinated with affected parties during project planning and installation. BLM field offices identified the following critical habitat improvements as being necessary:

- Fencing. Fencing reduces loss of riparian vegetation from overgrazing by livestock and protects overall habitat integrity. Dense riparian vegetation protects streambanks from erosion and provides shade, which cools water temperature. Alternate water supplies should be available to livestock if stream access is denied.

- Riparian Vegetation Management. Integrity of the aquatic habitat depends upon establishment and maintenance of riparian communities.

Table 5. Number of habitat improvements needed from fiscal years 1991 through 2000 for special status fishes on public lands.

\begin{tabular}{|l|rrrrrrrrrrr|}
\hline \multicolumn{1}{|c|}{ Improvements } & AZ & CA & CO & ID & MT & NM & NV & OR/WA & UT & WY & Total \\
\hline Fencing & 5 & 8 & 2 & 13 & 11 & 5 & 22 & 12 & 3 & 4 & 85 \\
\hline Riparian Veg. Mgmt. & 6 & 20 & 5 & 10 & 2 & 6 & 11 & 6 & 0 & 0 & 66 \\
\hline Instream Structure & 4 & 2 & 5 & 12 & 7 & 0 & 4 & 5 & 4 & 4 & 47 \\
\hline Maintenance & 7 & 8 & 5 & 13 & 8 & 1 & 26 & 9 & 6 & 4 & 87 \\
\hline Exotic Removal & 12 & 6 & 4 & 3 & 0 & 5 & 7 & 0 & 5 & 0 & 42 \\
\hline Stocking \& Reintrod. & 10 & 8 & 3 & 6 & 1 & 2 & 1 & 1 & 8 & 4 & 44 \\
\hline Barrier Construction & 3 & 2 & 2 & 0 & 0 & 1 & 4 & 0 & 0 & 3 & 15 \\
\hline Grazing Management & 2 & 1 & 0 & 5 & 3 & 0 & 13 & 2 & 2 & 5 & 33 \\
\hline Streamback Rehab. & 0 & 0 & 0 & 5 & 0 & 0 & 1 & 1 & 0 & 0 & 7 \\
\hline Spring \& Pond Dev. & 2 & 6 & 0 & 0 & 0 & 0 & 2 & 0 & 0 & 1 & 11 \\
\hline Barrier Removal & 0 & 0 & 0 & 1 & 0 & 0 & 0 & 5 & 1 & 0 & 7 \\
\hline Diversion Control & 6 & 1 & 0 & 3 & 0 & 1 & 0 & 0 & 0 & 1 & 12 \\
\hline \hline Total & 57 & 62 & 26 & 71 & 32 & 21 & 91 & 41 & 29 & 26 & 456 \\
\hline Workmonths & 255 & 85 & 68 & 241 & 51 & 35 & 240 & 123 & 105 & 85 & 1,288 \\
\$(000) & 1,653 & 729 & 375 & 2,130 & 444 & 301 & 2,400 & 1,439 & 813 & 740 & 11,024 \\
\hline
\end{tabular}


Where these communities are currently below recommended levels, recovery will be achieved by managing riparian use and, in some cases, reestablishing riparian species by planting desirable species or removing less desirable species. Once established, the communities will be maintained through management of grazing and other resource uses.

- Instream Structure. Instream structures, primarily large woody material, rock-filled gabions, and boulders, are integral to maintaining channel integrity and providing pools, spawning areas, cover, and habitat diversity. Introductions of beavers in some situations have provided additional habitat by their construction of pools and temporary dams.

- Maintenance. Two kinds of maintenance are proposed: (1) maintenance of structures, such as instream structures or fences; and (2) maintenance of aquatic habitat systems through management actions - once recommended levels for riparian and channel features have been achieved.
- Exotic Species Removal. Many introduced species are piscivorous or more aggressive than native species. Nonnative lishes also have introduced parasites and diseases that have decimated the native fauna. The Bureau has identified 42 nonnative species removal or control projects to protect or restore special status fish populations.

- Stocking and Reintroduction. Reintroductions involve placing species back into the native habitat they once occupied, but from which historical populations were extirpated. Stocking involves introducing species into suitable habitat witlin their native range, but where the species was not known to be present. Both methods increase the number of locations where a species can become established, thereby increasing the potential for survival of the species.

Reintroductions and restoekings will be coordinated with State fish and wildlife agencies. Movement of listed fishes also will be coordinated with the Fish and Wildlife Service.

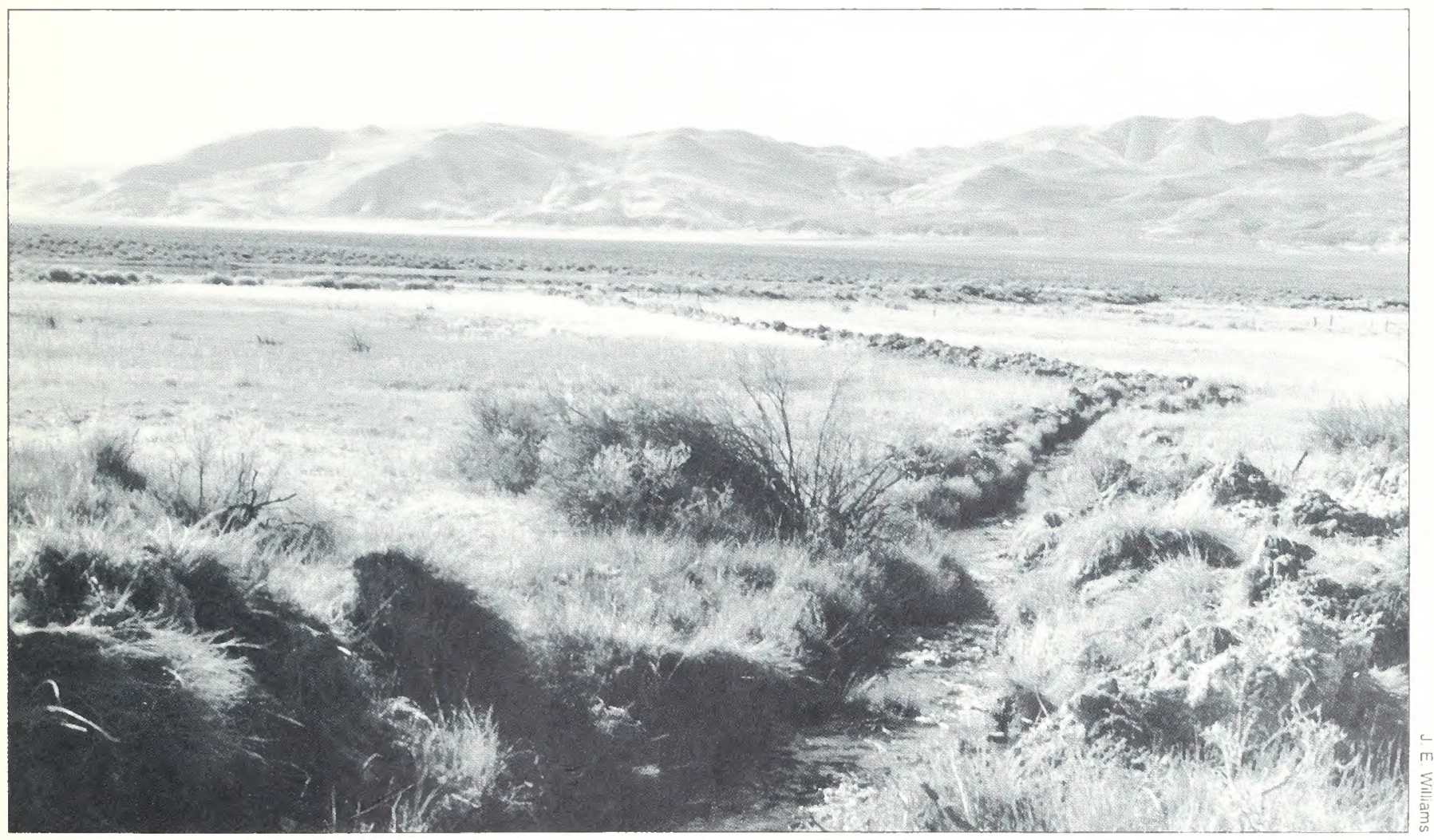

Alvord Desert, Oregon. Natural outflow channel from Borax Lake was deepened to increase water supplies and habitat at Lower Borax Lake. Side channels were added to increase riparian vegetation and marsh between the two habitats for the endangered Borax Lake chub. 
- Barrier Construction. Barriers are placed in habitats, usually streams, to limit access by undesirable species into habitat oceupied by native species. Barriers are usually artificial waterfalls which prevent fish from passing, regardless of the flow level.

- Grazing Management. Many proposed activity plans address grazing management activities. In most cases, grazing control will be addressed through land use and allotment management plans, and in specific cases, as part of fisheries habitat management plans.

- Streambank Rehabilitation. Most streambanks will heal with proper management of the aquatic system and associated watershed, but in some plans, vegetation, woody material, rock, or other materials were identified to hasten the stabilization and recovery of streambanks.

- Spring or Pond Development. Through changes in physical structure, such as silt removal to create pools, a pond or spring and its associated riparian communities can become suitable habitat for special status species. The changes may be proposed to reverse past alterations of the habitat that made it less suitable or to improve new locations for stocking.

- Barrier Removal. Many species, particularly those in isolated lake basins of the West, make upstream migrations to spawn; the young then move back downstream until they reach adulthood. Removal of barriers and screening of diversions allow safe, unimpeded movement for juveniles and adults.

- Diversion. Diversions can involve correcting instream flows caused by removal of water from the stream, or diverting water into new habitat.

\section{Action Item 7: Monitoring}

Table 6 identifies proposed monitoring of special status species and their habitats. This is in addition to general land use monitoring, and includes monitoring the effectiveness of habitat improvements and management actions specifically for the special status species, as well as monitoring the condition of the species. The schedule will permit rapid response if information suggests problems, or if repairs of facilities or changes in management are needed. The information will indicate how effective specific actions are, and whether more data are needed.

Table 6. Monitoring needed from fiscal years 1991 through 2000 for special status fishes on public lands.

\begin{tabular}{|c|rrrr|}
\hline State & Plans & Species & WM & $\$(\mathbf{0 0 0})$ \\
\hline AZ & 33 & 42 & 55 & 279 \\
\hline CA & 17 & 43 & 21 & 83 \\
\hline CO & 11 & 34 & 77 & 357 \\
\hline ID & 96 & 94 & 99 & 326 \\
\hline MT & 9 & 14 & 11 & 34 \\
\hline NM & 8 & 9 & 4 & 6 \\
\hline NV & 29 & 89 & 60 & 215 \\
\hline OR/WA & 132 & 121 & 158 & 518 \\
\hline UT & 14 & 45 & 72 & 277 \\
\hline WY & 12 & 41 & 65 & 163 \\
\hline \hline Total & 361 & 532 & 622 & 2,258 \\
\hline
\end{tabular}

\section{Action Item 8: Increase Awareness}

The value of special status fishes and their habitats often is underrated. Brochures, kiosks, interpretive trails and signs, and media articles all assist in increasing public awareness of the resource. Cooperative publications with the Fish and Wildlife Service may be appropriate for listed fishes. Interested parties should be encouraged to assist BLM in tracking activity plans and recovery plans for special status fishes and their habitats. 


\section{State Summaries and Maps}

The following pages summarize the status, threats, planned habitat improvements, and implementation results for special status fishes in each state. The plan results describe anticipated changes in species status if this strategy is fully implemented. Major special status fish habitats are shown on the maps with references to the fishes listed in the facing tables. Codes and abbreviations used in these tables are defined below.

\section{Present Status}

$\mathrm{FE}=$ listed as endangered by Federal government

FT $=$ listed as threatened by Federal government

$\mathrm{PE}=$ proposed as endangered by Federal government

PT $=$ proposed as threatened by Federal government

SL = listed by Statc government as endangered, threatened, or other protected category

$\mathrm{C} 1$ = category 1 candidate species

$\mathrm{C} 2$ = category 2 candidate species

$\mathrm{S}=\mathrm{BLM}$ sensitive species

\section{Threats}

1 = present or threatened destruction, modification, or curtailment of its habitat or range

2 = overutilization for commercial, recreational, scientific, or educational purposes

3 = disease

$4=$ other natural or manmade factors affecting continued existence (hybridization, introduction of exotic or transplanted species, predation, competition)

5 = restricted range

\section{Habitat Improvements}

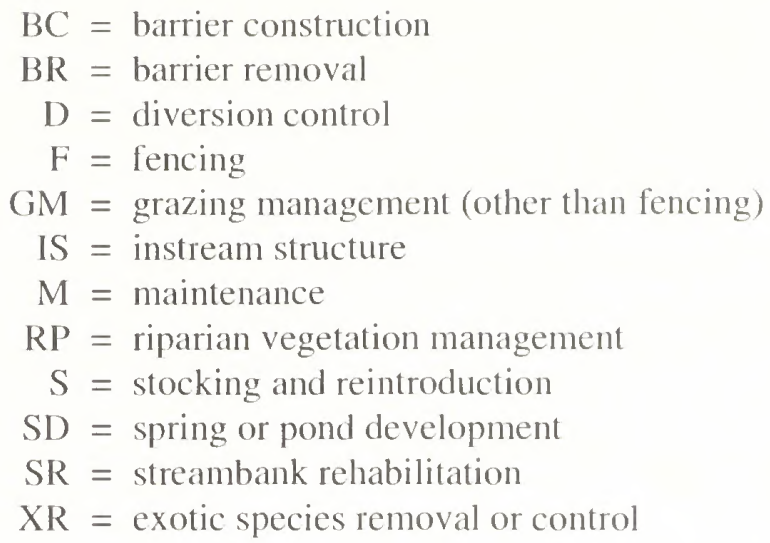

\section{Plan Results}

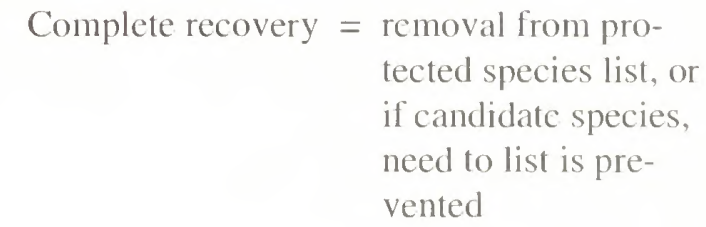
Reclassify from $\mathrm{E}$ to $\mathrm{T}=$ sufficient recovery to enable reclassification from endangered to threatened category

Prevent extinction $=$ sufficient protection to maintain one or more populations, but recovery is not achieved

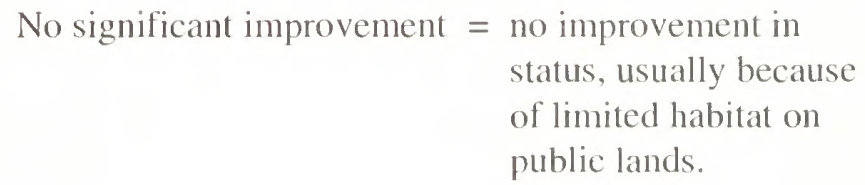
status, usually because of limited habitat on public lands. 
Table 7. Special status fishes of Arizona.

Threatened or Endangered

\begin{tabular}{|c|c|c|c|c|c|}
\hline Fish & $\begin{array}{l}\text { Present } \\
\text { Status }\end{array}$ & $\begin{array}{c}\text { Map } \\
\text { Symbol }\end{array}$ & $\begin{array}{l}\text { Habitat } \\
\text { Threats }\end{array}$ & $\begin{array}{c}\text { Plan } \\
\text { Improvements }\end{array}$ & Results \\
\hline Desert pupfish & $\mathrm{FE}, \mathrm{SL}$ & A & 1,4 & $\begin{array}{l}F, D, S, R P, M \\
S D, X R\end{array}$ & $E$ to $T$ \\
\hline Woundfin & $\mathrm{FE}, \mathrm{SL}$ & $B$ & $1,3,4$ & F,RP,S,IS,XR & $E$ to $T$ \\
\hline $\begin{array}{l}\text { Virgin River } \\
\text { chub }\end{array}$ & FE,SL & $\mathrm{C}$ & 1,4 & $\mathrm{~F}, \mathrm{RP}, \mathrm{S}, \mathrm{XR}$ & $E$ to $T$ \\
\hline Gila topminnow & FE,SL & $\mathrm{D}$ & 1,4 & $\begin{array}{l}F, S, D, M, X R \\
S D\end{array}$ & Recovery \\
\hline $\begin{array}{l}\text { Little Colorado } \\
\text { spinedace }\end{array}$ & FT,SL & $E$ & 1 & None ${ }^{1}$ & $\begin{array}{l}\text { Prevent } \\
\text { extinction }\end{array}$ \\
\hline Colorado squawfish & FE,SL & $\mathrm{F}$ & $1,3,4$ & $\mathrm{~S}, \mathrm{XR}$ & $\begin{array}{l}\text { Prevent } \\
\text { extinction }\end{array}$ \\
\hline Loach minnow & $\mathrm{FT}, \mathrm{SL}$ & $G$ & 1,4 & $\begin{array}{l}\text { BC,M,IS,S, } \\
\text { XR,D }\end{array}$ & $\begin{array}{l}\text { Prevent } \\
\text { extinction }\end{array}$ \\
\hline Spikedace & FT,SL & $\mathrm{H}$ & 1,4 & $\begin{array}{l}\mathrm{S}, \mathrm{IS}, \mathrm{BC}, \mathrm{M} \\
\mathrm{XR}, \mathrm{D}\end{array}$ & $\begin{array}{l}\text { Prevent } \\
\text { extinction }\end{array}$ \\
\hline \multicolumn{6}{|c|}{ Other Special Status Fishes } \\
\hline Virgin River spinedace & $\mathrm{C} 2, \mathrm{SL}$ & a & 1,4 & $\mathrm{~F}, \mathrm{RP}$ & $\begin{array}{l}\text { Prevent } \\
\text { extinction }\end{array}$ \\
\hline Gila chub & $\mathrm{C} 2, \mathrm{SL}$ & $b$ & 1,4 & $\begin{array}{l}\mathrm{D}, \mathrm{S}, \mathrm{RP}, \mathrm{F}, \mathrm{GM} \\
\mathrm{BC}, \mathrm{M}, \mathrm{XR}\end{array}$ & $\begin{array}{l}\text { Prevent } \\
\text { extinction }\end{array}$ \\
\hline $\begin{array}{l}\text { Colorado roundtail } \\
\text { chub }\end{array}$ & $\mathrm{SL}$ & $\mathrm{c}$ & 1 & $B C, D, M, S, X R$ & Recovery \\
\hline Razorback sucker & $\mathrm{PE}, \mathrm{SL}$ & $\mathrm{d}$ & $1,2,4$ & $\begin{array}{l}\mathrm{S}, \mathrm{M}, \mathrm{XR}, \mathrm{IS}, \mathrm{F} \\
\mathrm{GM}, \mathrm{RP}, \mathrm{SD}\end{array}$ & $\begin{array}{l}\text { Prevent } \\
\text { extinction }\end{array}$ \\
\hline $\begin{array}{l}\text { Little Colorado } \\
\text { sucker }\end{array}$ & SL & e & 1 & None $^{1}$ & $\begin{array}{l}\text { No significant } \\
\text { improvement }\end{array}$ \\
\hline Zuni bluehead sucker & $\mathrm{C} 2, \mathrm{SL}$ & $f$ & 1 & None $^{1}$ & $\begin{array}{l}\text { No significant } \\
\text { improvement }\end{array}$ \\
\hline
\end{tabular}


Locations of Special Status Fishes on BLM Lands in Arizona

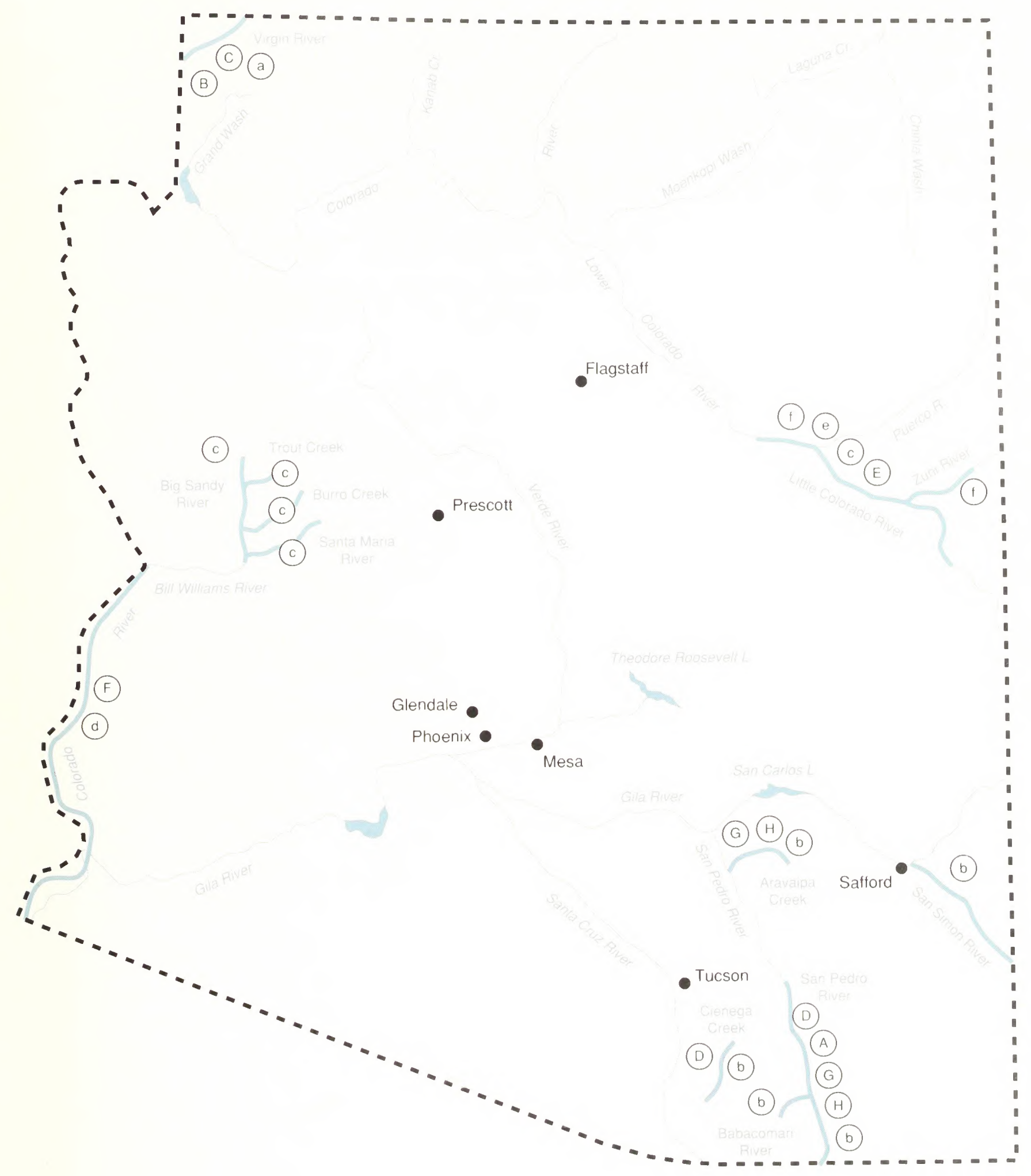


Table 8. Special status fishes of California.

\begin{tabular}{|c|c|c|c|c|c|}
\hline \multicolumn{6}{|c|}{ Threatened or Endangered } \\
\hline Fish & $\begin{array}{l}\text { Present } \\
\text { Status }\end{array}$ & $\begin{array}{c}\text { Map } \\
\text { Symbol }\end{array}$ & $\begin{array}{l}\text { Habitat } \\
\text { Threats }\end{array}$ & $\begin{array}{c}\text { Plan } \\
\text { Improvements }\end{array}$ & Results \\
\hline $\begin{array}{l}\text { Winter chinook } \\
\text { salmon }\end{array}$ & FT,SL & A & 1,4 & $\mathrm{M}, \mathrm{RP}$ & $\begin{array}{l}\text { Prevent } \\
\text { extinction }\end{array}$ \\
\hline $\begin{array}{l}\text { Lahontan cutthroat } \\
\text { trout }\end{array}$ & FT & $\mathrm{B}$ & 1,4 & XR,S,F,IS,RP & Recovery \\
\hline Owens pupfish & FE,SL & C & 1,4 & $\begin{array}{l}F, S, M, X R, R P, \\
S D\end{array}$ & $E$ to $T$ \\
\hline Owens tui chub & FE,SL & $\mathrm{D}$ & $1,4,5$ & $\begin{array}{l}F, S, M, X R, R P, \\
S D\end{array}$ & $\begin{array}{l}\text { Prevent } \\
\text { extinction }\end{array}$ \\
\hline Modoc sucker & FE,SL & $E$ & 1,4 & $\mathrm{~F}, \mathrm{BC}, \mathrm{S}$ & $\begin{array}{l}\text { Prevent } \\
\text { extinction }\end{array}$ \\
\hline Desert pupfish & FE,SL & $\mathrm{F}$ & 1,4 & $\mathrm{BC}, \mathrm{RP}, \mathrm{SD}, \mathrm{M}$ & $\mathrm{E}$ to $\mathrm{T}$ \\
\hline Mohave tui chub & FE,SL & $G$ & 1,4 & $\mathrm{SD}, \mathrm{RP}, \mathrm{D}$ & $\mathrm{E}$ to $\mathrm{T}$ \\
\hline $\begin{array}{l}\text { Unarmored threespine } \\
\text { stickleback }\end{array}$ & FE,SL & $\mathrm{H}$ & 1,4 & None $^{1}$ & $\begin{array}{l}\text { No significant } \\
\text { improvement }\end{array}$ \\
\hline Lost River sucker & FE,SL & 1 & $1,2,4$ & None $^{1}$ & $\begin{array}{l}\text { Prevent } \\
\text { extinction }\end{array}$ \\
\hline Shortnose sucker & FE,SL & $\mathrm{J}$ & 1,4 & None ${ }^{1}$ & $\begin{array}{l}\text { Prevent } \\
\text { extinction }\end{array}$ \\
\hline \multicolumn{6}{|c|}{ Other Special Status Fishes } \\
\hline $\begin{array}{l}\text { Cowhead Lake tui } \\
\text { chub }\end{array}$ & $\mathrm{C} 1$ & a & 1,5 & $\mathrm{~F}, \mathrm{GM}$ & Recovery \\
\hline $\begin{array}{l}\text { Amargosa Canyon } \\
\text { speckled dace }\end{array}$ & $\mathrm{C} 2$ & $b$ & 1,5 & $R P, M$ & Recovery \\
\hline Amargosa pupfish & $\mathrm{C} 2$ & $\mathrm{c}$ & 1,4 & $\mathrm{RP}, \mathrm{M}$ & Recovery \\
\hline Goose Lake sucker & $\mathrm{C} 2$ & $d$ & 1,4 & None ${ }^{1}$ & $\begin{array}{l}\text { No significant } \\
\text { improvement }\end{array}$ \\
\hline Redband trout & $\mathrm{C} 2$ & e & $1,2,4$ & None ${ }^{1}$ & Recovery \\
\hline $\begin{array}{l}\text { Klamath largescale } \\
\text { sucker }\end{array}$ & $\mathrm{C} 2$ & $f$ & $1,2,4$ & None $^{1}$ & $\begin{array}{l}\text { Prevent } \\
\text { extinction }\end{array}$ \\
\hline Razorback sucker & PE,SL & $g$ & $1,2,4$ & None ${ }^{1}$ & $\begin{array}{l}\text { Prevent } \\
\text { extinction }\end{array}$ \\
\hline $\begin{array}{l}\text { Summer steelhead } \\
\text { trout }\end{array}$ & $S$ & $\mathrm{~h}$ & $1,2,4$ & $\mathrm{RP}$ & $\begin{array}{l}\text { Prevent } \\
\text { extinction }\end{array}$ \\
\hline
\end{tabular}


Locations of Special Status Fishes on BLM Lands in California

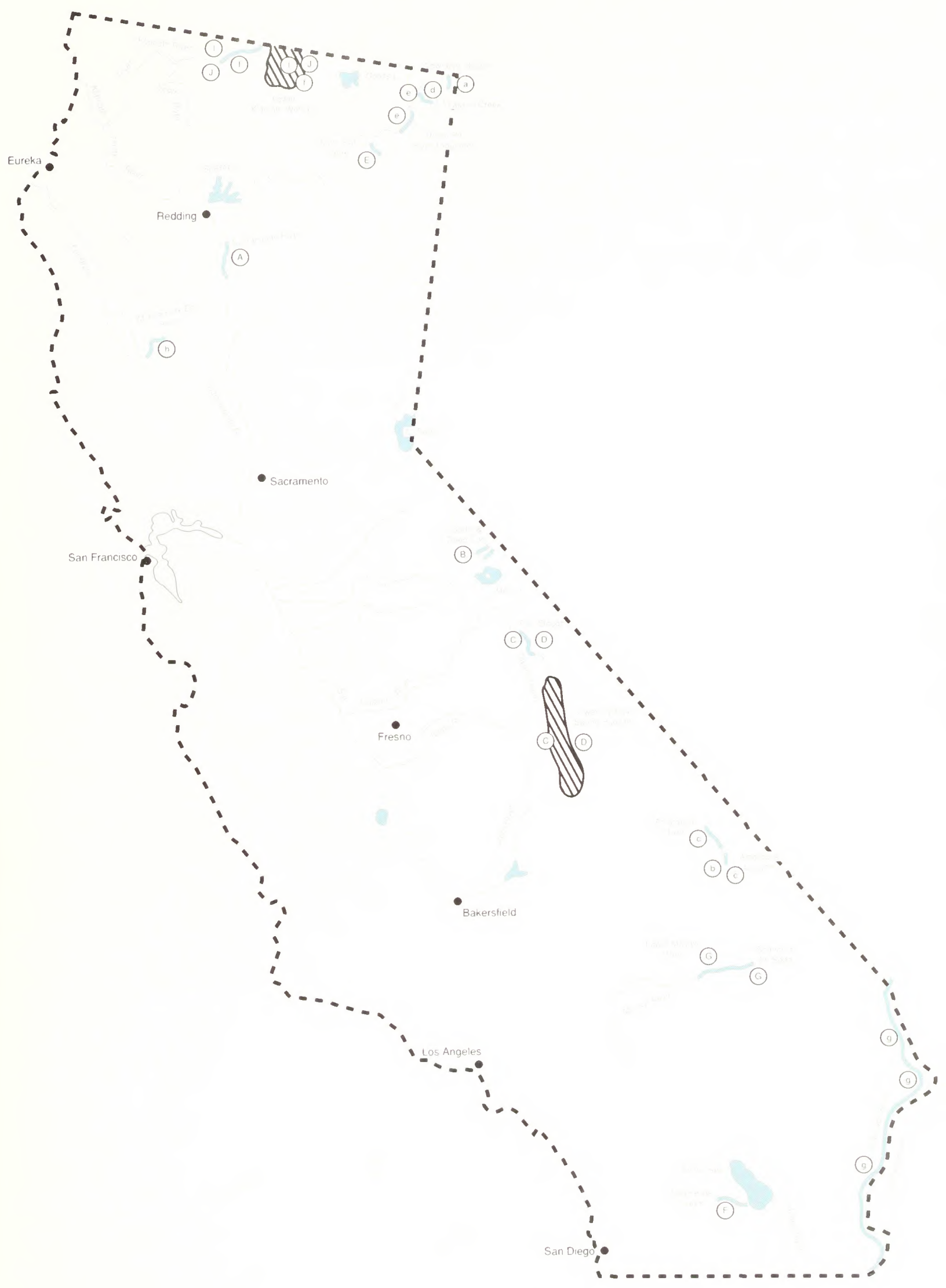


Table 9. Special status fishes of Colorado.

\begin{tabular}{|c|c|c|c|c|c|}
\hline \multicolumn{6}{|c|}{ Threatened or Endangered } \\
\hline Fish & $\begin{array}{l}\text { Present } \\
\text { Status }\end{array}$ & $\begin{array}{c}\text { Map } \\
\text { Symbol }\end{array}$ & $\begin{array}{l}\text { Habitat } \\
\text { Threats }\end{array}$ & Improvements & $\begin{array}{c}\text { Plan } \\
\text { Results }\end{array}$ \\
\hline Colorado squawfish & FE,SL & A & $1,3,4$ & M & $\begin{array}{l}\text { Prevent } \\
\text { extinction }\end{array}$ \\
\hline Bonytail chub & FE,SL & $\mathrm{B}$ & 1,4 & $M$ & $\begin{array}{l}\text { No significant } \\
\text { improvement }\end{array}$ \\
\hline Humpback chub & FE,SL & C & 1,4 & M & $\begin{array}{l}\text { No significant } \\
\text { improvement }\end{array}$ \\
\hline $\begin{array}{l}\text { Greenback cutthroat } \\
\text { trout }\end{array}$ & FT,SL & $\mathrm{D}$ & 1,4 & $\mathrm{BC}, \mathrm{XR}, \mathrm{S}$ & $\begin{array}{l}\text { Prevent } \\
\text { extinction }\end{array}$ \\
\hline \multicolumn{6}{|c|}{ Other Special Status Fishes } \\
\hline Razorback sucker & $\mathrm{PE}, \mathrm{SL}$ & $\mathrm{a}$ & $1,2,4$ & IS,RP,M & $\begin{array}{l}\text { Prevent } \\
\text { extinction }\end{array}$ \\
\hline $\begin{array}{l}\text { Colorado cutthroat } \\
\text { trout }\end{array}$ & $\mathrm{C} 2$ & $\mathrm{~b}$ & 1,4 & $R P, F, I S, X R, M$ & Recovery \\
\hline $\begin{array}{l}\text { Rio Grande cutthroat } \\
\text { trout }\end{array}$ & $S$ & c & 1,4 & $\mathrm{~S}, \mathrm{BC}, \overline{\mathrm{XR}}$ & $\begin{array}{l}\text { Prevent } \\
\text { extinction }\end{array}$ \\
\hline Southern redbelly dace & $\mathrm{S}$ & $d$ & 1 & IS,RP,F & $\begin{array}{l}\text { Prevent } \\
\text { extinction }\end{array}$ \\
\hline Arkansas darter & $\mathrm{C} 2, \mathrm{SL}$ & e & 1 & None $^{1}$ & $\begin{array}{l}\text { Prevent } \\
\text { extinction }\end{array}$ \\
\hline $\begin{array}{l}\text { Arkansas River } \\
\text { speckled chub }\end{array}$ & SL & $f$ & 1 & None' & $\begin{array}{l}\text { Prevent } \\
\text { extinction }\end{array}$ \\
\hline Common shiner & $S$ & $g$ & 1 & None $^{1}$ & $\begin{array}{l}\text { Prevent } \\
\text { extinction }\end{array}$ \\
\hline $\begin{array}{l}\text { Plains orangethroat } \\
\text { darter }\end{array}$ & $\mathrm{S}$ & $\mathrm{h}$ & 1 & None $^{1}$ & $\begin{array}{l}\text { Prevent } \\
\text { extinction }\end{array}$ \\
\hline $\begin{array}{l}\text { Colorado roundtail } \\
\text { chub }\end{array}$ & $\mathrm{S}$ & i & 1 & IS,RP & Recovery \\
\hline
\end{tabular}


Locations of Special Status Fishes on BLM Lands in Colorado

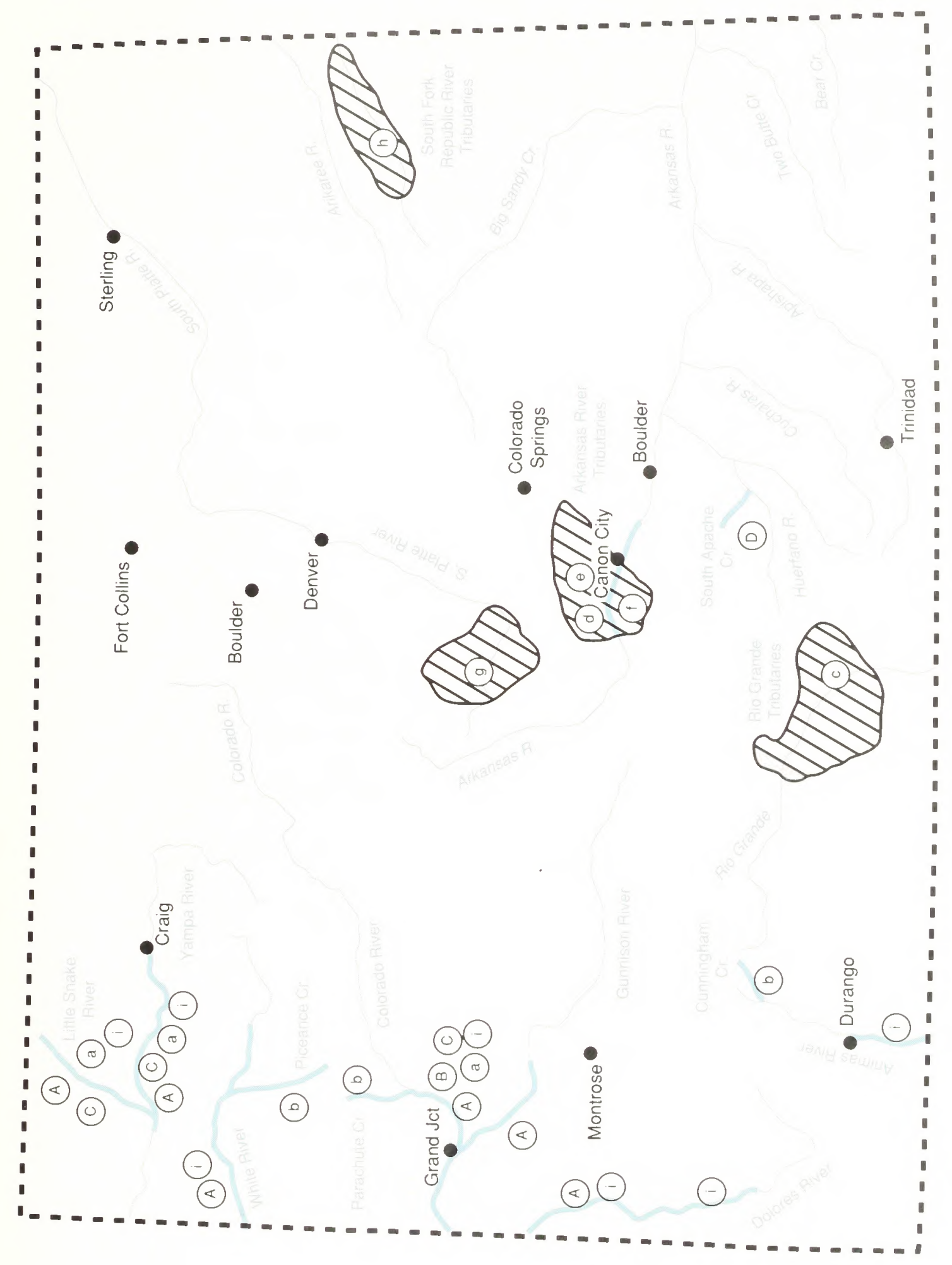


Table 10. Special status fishes of Idaho.

Threatened or Endangered

\begin{tabular}{|c|c|c|c|c|c|}
\hline Fish & $\begin{array}{l}\text { Present } \\
\text { Status }\end{array}$ & $\begin{array}{c}\text { Map } \\
\text { Symbol }\end{array}$ & Threats & $\begin{array}{c}\text { Habitat } \\
\text { Improvements }\end{array}$ & $\begin{array}{c}\text { Plan } \\
\text { Results }\end{array}$ \\
\hline $\begin{array}{l}\text { Lahontan cutthroat } \\
\text { trout }\end{array}$ & FT & A & 1,4 & F,SD & Recovery \\
\hline \multicolumn{6}{|c|}{ Other Special Status Fishes } \\
\hline Redband trout & $\mathrm{C} 2, \mathrm{~S}, \mathrm{SL}$ & a & $1,2,4$ & $F, I S, R P, M, D$ & Recovery \\
\hline Bull trout & $\mathrm{C} 2$ & $\mathrm{~b}$ & 1,4 & $\mathrm{M}, F, I S, R P, S R$ & Recovery \\
\hline Shoshone sculpin & $\mathrm{S}, \mathrm{SL}$ & c & 1,5 & $\mathrm{RP}$ & $\begin{array}{l}\text { Prevent } \\
\text { extinction }\end{array}$ \\
\hline $\begin{array}{l}\text { Bear Lake cutthroat } \\
\text { trout }\end{array}$ & $\mathrm{S}$ & $d$ & 1,4 & IS,BR & $\begin{array}{l}\text { Prevent } \\
\text { extinction }\end{array}$ \\
\hline Chinook salmon & $\begin{array}{l}\text { SL,S, } \\
\text { PT }\end{array}$ & e & $1,2,4$ & F,IS,RP,SR,M & $\begin{array}{l}\text { Prevent } \\
\text { extinction }\end{array}$ \\
\hline White sturgeon & $\mathrm{S}, \mathrm{SL}$ & $f$ & $1,2,4$ & IS,SR,RP,M & $\begin{array}{l}\text { Prevent } \\
\text { extinction }\end{array}$ \\
\hline Wood River sculpin & $\mathrm{C} 2, \mathrm{~S}$ & $g$ & 1 & None $^{1}$ & $\begin{array}{l}\text { Prevent } \\
\text { extinction }\end{array}$ \\
\hline Sockeye salmon & $\begin{array}{l}\text { C2,SL, } \\
\text { S, PE }\end{array}$ & $\mathrm{h}$ & $1,2,4$ & IS,RP,SR & $\begin{array}{l}\text { Prevent } \\
\text { extinction }\end{array}$ \\
\hline Steelhead trout & S & $\mathrm{i}$ & $1,2,4$ & IS,F,RP,SR,M & $\begin{array}{l}\text { Prevent } \\
\text { extinction }\end{array}$ \\
\hline Leatherside chub & $\mathrm{C} 2, \mathrm{SL}$ & j & 1 & None ${ }^{1}$ & $\begin{array}{l}\text { No significant } \\
\text { improvement }\end{array}$ \\
\hline $\begin{array}{l}\text { Westslope cutthroat } \\
\text { trout }\end{array}$ & $\mathrm{S}$ & k & 1,4 & GM,S,M & Recovery \\
\hline $\begin{array}{l}\text { Bonneville cutthroat } \\
\text { trout }\end{array}$ & $\mathrm{C} 2, \mathrm{~S}$ & 1 & 1,4 & $\begin{array}{l}\text { GM,IS,S, } \\
X R, M\end{array}$ & Recovery \\
\hline $\begin{array}{l}\text { Yellowstone cutthroat } \\
\text { trout }\end{array}$ & SL & $\mathrm{m}$ & 1,4 & $\mathrm{D}, \mathrm{F}, \mathrm{GM}$ & $\begin{array}{l}\text { Prevent } \\
\text { extinction }\end{array}$ \\
\hline
\end{tabular}


Locations of Special Status Fishes on BLM Lands in Idaho

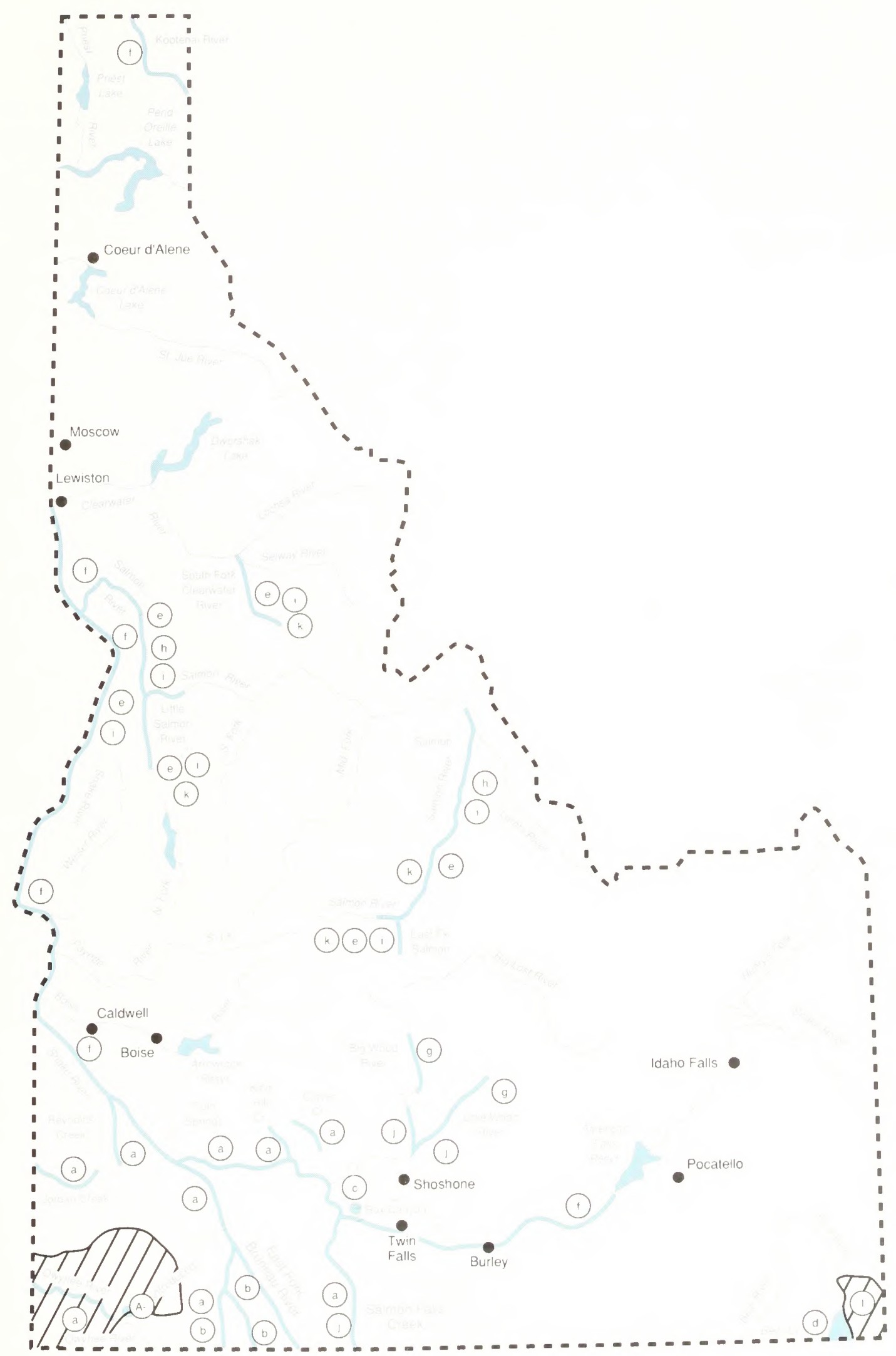


Table 11. Special status fishes of Montana.

\begin{tabular}{|c|c|c|c|c|c|}
\hline \multicolumn{6}{|c|}{ Threatened or Endangered } \\
\hline Fish & $\begin{array}{l}\text { Present } \\
\text { Status }\end{array}$ & $\begin{array}{c}\text { Map } \\
\text { Symbol }\end{array}$ & Threats & $\begin{array}{c}\text { Habitat } \\
\text { Improvements }\end{array}$ & $\begin{array}{c}\text { Plan } \\
\text { Results }\end{array}$ \\
\hline Pallid sturgeon & FE,SL & A & 1,4 & None ${ }^{1}$ & $\begin{array}{l}\text { No significant } \\
\text { improvement }\end{array}$ \\
\hline \multicolumn{6}{|c|}{ Other Special Status Fishes } \\
\hline Bull trout & $\mathrm{C} 2$ & $\mathrm{a}$ & 1,4 & $\mathrm{~F}, \mathrm{GM}$ & Recovery \\
\hline $\begin{array}{l}\text { Northern redbelly } \\
\text { dace }\end{array}$ & SL & $\mathrm{b}$ & 1 & F,GM & Recovery \\
\hline Sturgeon chub & C2,SL & $\mathrm{C}$ & 1 & $\mathrm{~F}, \mathrm{GM}$ & Recovery \\
\hline $\begin{array}{l}\text { Yellowstone cutthroat } \\
\text { trout }\end{array}$ & SL & $d$ & 1,4 & $F, I S, M$ & $\begin{array}{l}\text { Prevent } \\
\text { extinction }\end{array}$ \\
\hline $\begin{array}{l}\text { Westslope cutthroat } \\
\text { trout }\end{array}$ & SL & e & 1,4 & $S, F, I S, M, R P$ & Recovery \\
\hline $\begin{array}{l}\text { Montana Arctic } \\
\text { grayling }\end{array}$ & $\mathrm{C} 2, \mathrm{SL}$ & $f$ & 1 & F,RP,IS & $\begin{array}{l}\text { Prevent } \\
\text { extinction }\end{array}$ \\
\hline Shorthead sculpin & SL & $g$ & 1 & None ${ }^{1}$ & $\begin{array}{l}\text { Prevent } \\
\text { extinction }\end{array}$ \\
\hline Finescale dace & $\mathrm{SL}$ & $\mathrm{h}$ & 1 & None & $\begin{array}{l}\text { No significant } \\
\text { improvement }\end{array}$ \\
\hline Paddlefish & SL & $\mathrm{i}$ & 1 & None $^{1}$ & $\begin{array}{l}\text { No significant } \\
\text { improvement }\end{array}$ \\
\hline Sicklefin chub & SL & j & 1 & None $^{1}$ & $\begin{array}{l}\text { No significant } \\
\text { improvement }\end{array}$ \\
\hline Pearl dace & SL & k & 1 & None $^{1}$ & $\begin{array}{l}\text { Prevent } \\
\text { extinction }\end{array}$ \\
\hline
\end{tabular}


Locations of Special Status Fishes on BLM Lands in Montana

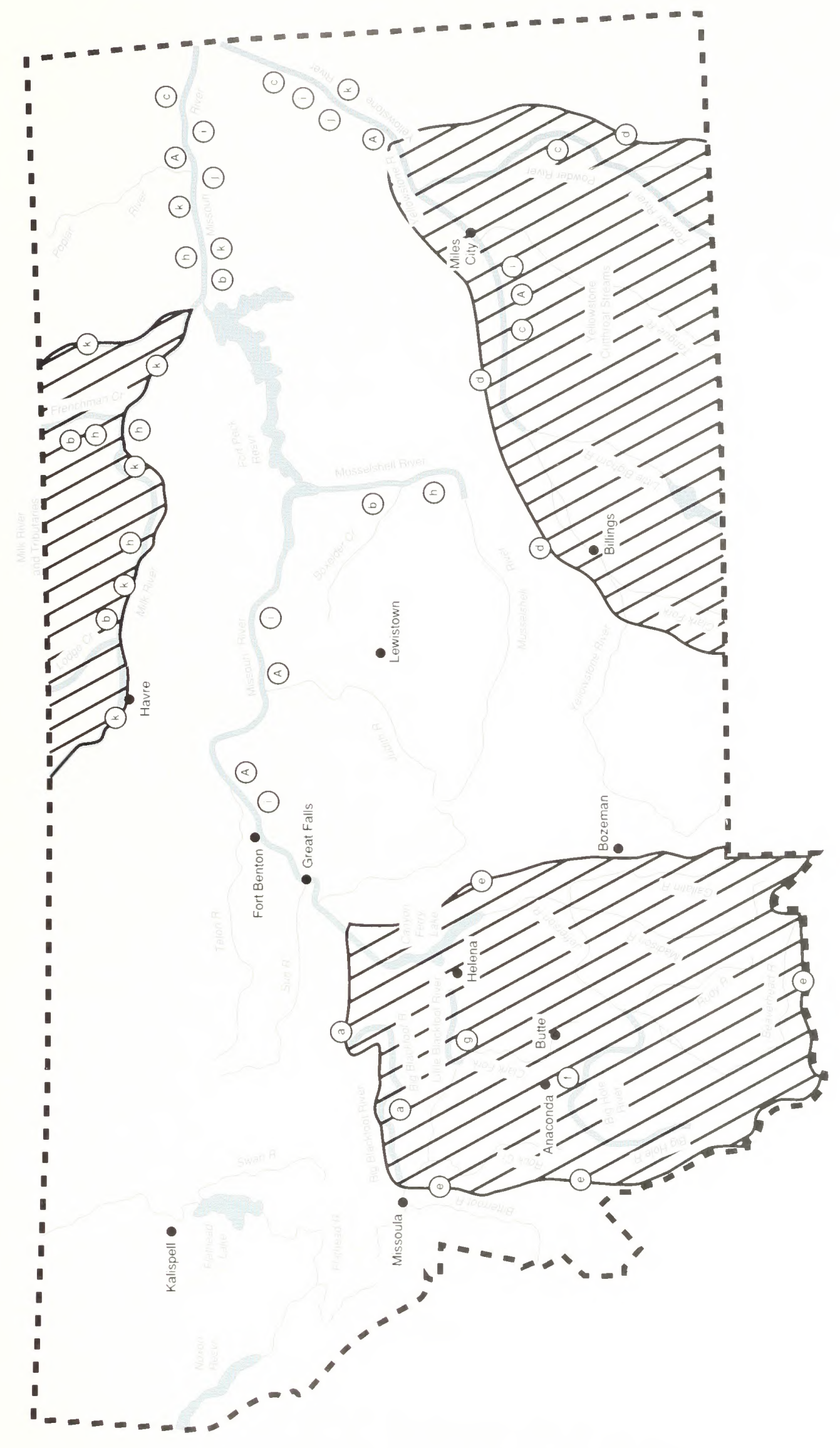


Table 12. Special status fishes of Nevada.

\begin{tabular}{|c|c|c|c|c|c|}
\hline \multicolumn{6}{|c|}{ Threatened or Endangered } \\
\hline Fish & $\begin{array}{l}\text { Present } \\
\text { Status }\end{array}$ & $\begin{array}{c}\text { Map } \\
\text { Symbol }\end{array}$ & Threats & $\begin{array}{c}\text { Habitat } \\
\text { Improvements }\end{array}$ & $\begin{array}{c}\text { Plan } \\
\text { Results }\end{array}$ \\
\hline $\begin{array}{l}\text { Lahontan cutthroat } \\
\text { trout }\end{array}$ & FT & A & 1,4 & $M, F, R P, X R, B C$ & Recovery \\
\hline Woundfin & FE,SL & $\mathrm{B}$ & $1,3,4$ & None $^{1}$ & $E$ to $T$ \\
\hline Virgin River chub & $\mathrm{FE}, \mathrm{SL}$ & $\mathrm{C}$ & 1 & None $^{1}$ & $E$ to $T$ \\
\hline $\begin{array}{l}\text { White River } \\
\text { springfish }\end{array}$ & $\mathrm{FE}, \mathrm{SL}$ & D & $1,3,4,5$ & F,SR & Recovery \\
\hline Hiko springfish & $\mathrm{FE}, \mathrm{SL}$ & $E$ & 1,4 & $\mathrm{RP}$ & Recovery \\
\hline $\begin{array}{l}\text { Railroad Valley } \\
\text { springfish }\end{array}$ & FT,SL & $F$ & 1,4 & M,GM & Recovery \\
\hline Pahrump poolfish & $\mathrm{FE}, \mathrm{SL}$ & G & $1,4,5$ & $\mathrm{M}, \mathrm{SD}$ & Recovery \\
\hline Big Spring spinedace & FT,SL & $\mathrm{H}$ & 1,4 & F,IS,RP & Recovery \\
\hline Desert dace & FT,SL & 1 & 1,5 & $F, G M, S D, M$ & Recovery \\
\hline $\begin{array}{l}\text { Ash Meadows speckled } \\
\text { dace }\end{array}$ & FE,SL & $\mathrm{J}$ & 1,4 & M,ER,BC & $E$ to $T$ \\
\hline Warm springs pupfish & $\mathrm{FE}, \mathrm{SL}$ & $\mathrm{K}$ & $1,4,5$ & $\mathrm{M}$ & $\mathrm{E}$ to $\mathrm{T}$ \\
\hline Ash Meadows pupfish & $\mathrm{FE}, \mathrm{SL}$ & $L$ & 1,4 & $M, E R, B C$ & $E$ to $T$ \\
\hline Cui-ui & $\mathrm{FE}, \mathrm{SL}$ & M & 1 & None $^{1}$ & $\begin{array}{l}\text { Prevent } \\
\text { extinction }\end{array}$ \\
\hline \multicolumn{6}{|c|}{ Other Special Status Fishes } \\
\hline Dixie Valley tui chub & $\mathrm{C} 2, \mathrm{SL}$ & $\mathrm{a}$ & 1,5 & None ${ }^{1}$ & $\begin{array}{l}\text { Prevent } \\
\text { extinction }\end{array}$ \\
\hline Lahontan tui chub & $\mathrm{C} 2, \mathrm{SL}$ & $\mathrm{b}$ & 1 & None ${ }^{1}$ & Recovery \\
\hline $\begin{array}{l}\text { Newark Valley } \\
\text { tui chub }\end{array}$ & $\mathrm{C} 2, \mathrm{SL}$ & $\mathrm{C}$ & 1,5 & None ${ }^{1}$ & $\begin{array}{l}\text { Prevent } \\
\text { extinction }\end{array}$ \\
\hline $\begin{array}{l}\text { Railroad Valley } \\
\text { tui chub }\end{array}$ & $\mathrm{C} 2, \mathrm{SL}$ & d & 1,5 & None $^{1}$ & $\begin{array}{l}\text { Prevent } \\
\text { extinction }\end{array}$ \\
\hline $\begin{array}{l}\text { Meadow Valley Wash } \\
\text { desert sucker }\end{array}$ & $\mathrm{C} 2, \mathrm{SL}$ & $\mathrm{e}$ & 1 & F,IS,RP & Recovery \\
\hline $\begin{array}{l}\text { Meadow Valley Wash } \\
\text { speckled dace }\end{array}$ & $\mathrm{C} 2, \mathrm{SL}$ & $f$ & 1 & F,IS,RP & Recovery \\
\hline Relict dace & $\mathrm{C} 2, \mathrm{SL}$ & $\mathrm{g}$ & 1 & $F, M$ & Recovery \\
\hline $\begin{array}{l}\text { White River desert } \\
\text { sucker }\end{array}$ & $\mathrm{C} 2, \mathrm{SL}$ & $\mathrm{h}$ & 1,4 & F,IS,BC & $\begin{array}{l}\text { Prevent } \\
\text { extinction }\end{array}$ \\
\hline Wall Canyon sucker & $\mathrm{C} 2, \mathrm{SL}$ & $\mathrm{i}$ & 1,5 & GM,M & Recovery \\
\hline Sheldon tui chub & $\mathrm{C} 2, \mathrm{SL}$ & j & 1,5 & None ${ }^{1}$ & Recovery \\
\hline $\begin{array}{l}\text { Virgin River } \\
\text { spinedace }\end{array}$ & $\mathrm{C} 2, \mathrm{SL}$ & $\mathrm{k}$ & 1,4 & None ${ }^{1}$ & $\begin{array}{l}\text { Prevent } \\
\text { extinction }\end{array}$ \\
\hline Razorback sucker & PE,SL & 1 & $1,2,4$ & None ${ }^{1}$ & $\begin{array}{l}\text { Prevent } \\
\text { extinction }\end{array}$ \\
\hline Redband trout & $\mathrm{C} 2$ & $m$ & $1,2,4$ & $F, G M$ & Recovery \\
\hline $\begin{array}{l}\text { Bonnevile cutthroat } \\
\text { trout }\end{array}$ & $\mathrm{C} 2$ & $n$ & 1,4 & $F, M, G M$ & Recovery \\
\hline Alvord chub & $\mathrm{C} 2$ & 0 & 1,4 & GM & Recovery \\
\hline
\end{tabular}


Locations of Special Status Fishes on BLM Lands in Nevada

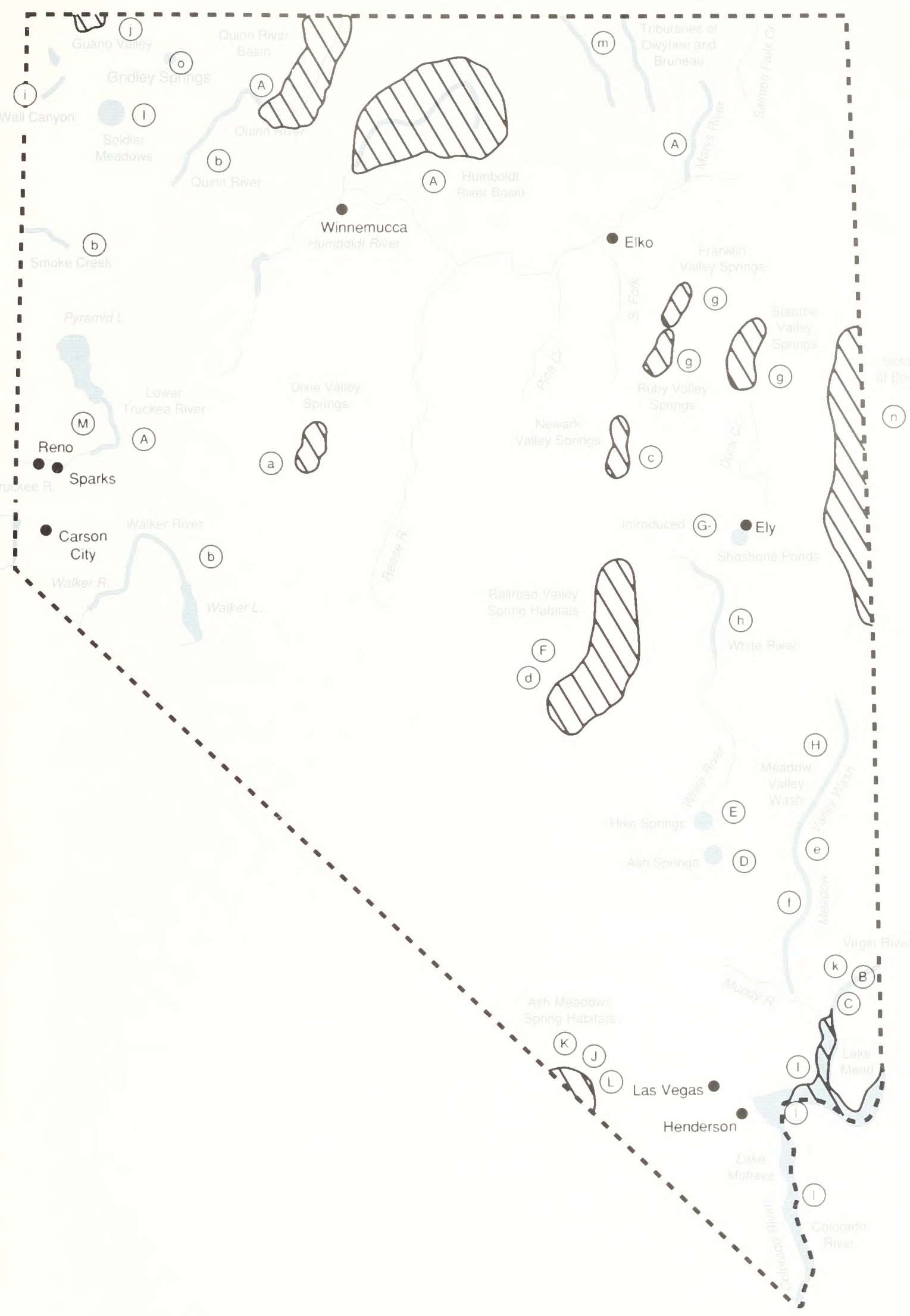


Table 13. Special status fishes of New Mexico.

\begin{tabular}{|c|c|c|c|c|c|}
\hline \multicolumn{6}{|c|}{ Threatened or Endangered } \\
\hline Fish & $\begin{array}{l}\text { Present } \\
\text { Status }\end{array}$ & $\begin{array}{c}\text { Map } \\
\text { Symbol }\end{array}$ & Threats & $\begin{array}{c}\text { Habitat } \\
\text { Improvements }\end{array}$ & $\begin{array}{c}\text { Plan } \\
\text { Results }\end{array}$ \\
\hline Loach minnow & FT,SL & A & 1,4 & None ${ }^{1}$ & $\begin{array}{l}\text { Prevent } \\
\text { extinction }\end{array}$ \\
\hline Spikedace & FT,SL & $\mathrm{B}$ & 1,4 & None ${ }^{1}$ & $\begin{array}{l}\text { Prevent } \\
\text { extinction }\end{array}$ \\
\hline $\begin{array}{l}\text { Pecos bluntnose } \\
\text { shiner }\end{array}$ & $\mathrm{FT}, \mathrm{SL}$ & $\mathrm{C}$ & 1,4 & $\mathrm{RP}$ & $\begin{array}{l}\text { Prevent } \\
\text { extinction }\end{array}$ \\
\hline Pecos gambusia & FE,SL & $\mathrm{D}$ & 1,4 & $M, F$ & $\begin{array}{l}\text { Prevent } \\
\text { extinction }\end{array}$ \\
\hline Colorado squawfish & FE & $E$ & $1,3,4$ & None $^{1}$ & $\begin{array}{l}\text { Prevent } \\
\text { extinction }\end{array}$ \\
\hline \multicolumn{6}{|c|}{ Other Special Status Fishes } \\
\hline Razorback sucker & PE & a & $1,2,4$ & $\mathrm{~S}$ & $\begin{array}{l}\text { Prevent } \\
\text { extinction }\end{array}$ \\
\hline Zuni bluehead sucker & $\mathrm{C} 2, \mathrm{SL}$ & $\mathrm{b}$ & 1 & None $^{-}$ & $\begin{array}{l}\text { No significant } \\
\text { improvement }\end{array}$ \\
\hline Bigscale logperch & $\mathrm{SL}$ & $\mathrm{c}$ & 1 & $\mathrm{~F}, \mathrm{RP}, \mathrm{XR}$ & Recovery \\
\hline Blue sucker & $\mathrm{C} 2, \mathrm{SL}$ & $d$ & 1,4 & None ${ }^{1}$ & $\begin{array}{l}\text { No significant } \\
\text { improvement }\end{array}$ \\
\hline Greenthroat darter & SL & e & 1 & $F, R P, X R, D C$ & Recovery \\
\hline Grey redhorse & SL & $f$ & 1 & $\mathrm{~F}, \mathrm{RP}, \mathrm{XR}$ & Recovery \\
\hline Mexican tetra & $S L$ & g & 1 & $\mathrm{~F}, \mathrm{RP}, \mathrm{XR}$ & Recovery \\
\hline Gila roundtail chub & $\mathrm{C} 2, \mathrm{SL}$ & $\mathrm{h}$ & 1,4 & $\mathrm{BC}, \mathrm{RP}, \mathrm{XR}$ & $\begin{array}{l}\text { Prevent } \\
\text { extinction }\end{array}$ \\
\hline $\begin{array}{l}\text { Colorado roundtail } \\
\text { chub }\end{array}$ & $S L$ & $\mathrm{i}$ & 1 & None $^{1}$ & Recovery \\
\hline Pecos pupfish & $\mathrm{C} 1, \mathrm{SL}$ & $\bar{j}$ & 1,4 & None ${ }^{1}$ & $\begin{array}{l}\text { No significant } \\
\text { improvement }\end{array}$ \\
\hline
\end{tabular}




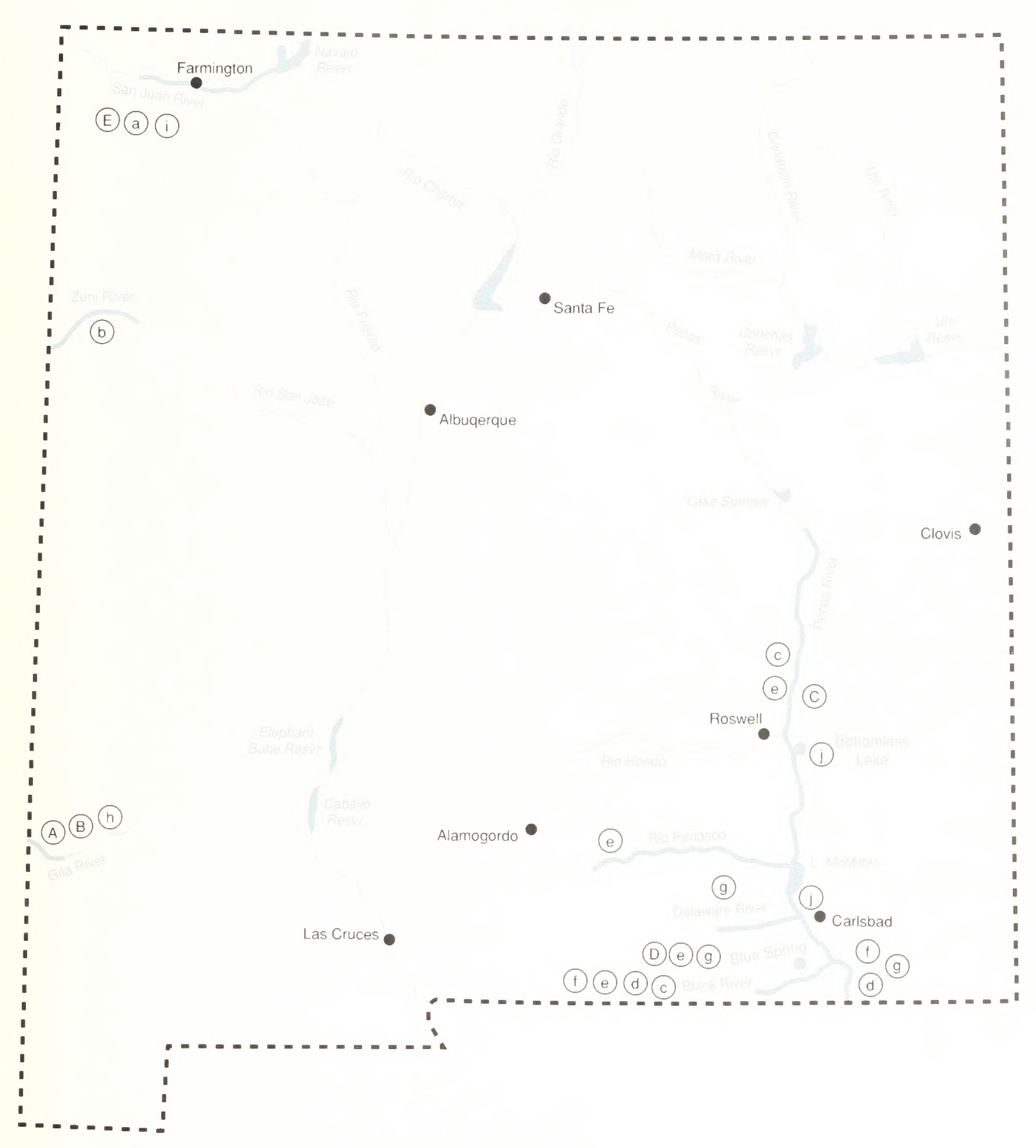


Table 14. Special status fishes of Oregon.

\begin{tabular}{|c|c|c|c|c|c|}
\hline \multicolumn{6}{|c|}{ Threatened or Endangered } \\
\hline Fish & $\begin{array}{l}\text { Present } \\
\text { Status }\end{array}$ & $\begin{array}{c}\text { Map } \\
\text { Symbol }\end{array}$ & Threats & $\begin{array}{c}\text { Habitat } \\
\text { Improvements }\end{array}$ & $\begin{array}{c}\text { Plan } \\
\text { Results }\end{array}$ \\
\hline $\begin{array}{l}\text { Lahontan cutthroat } \\
\text { trout }\end{array}$ & FT,SL & $A$ & 1,4 & $F, M, P S, B R, R P$ & Recovery \\
\hline $\begin{array}{l}\text { Foskett speckled } \\
\text { dace }\end{array}$ & FT,SL & B & 1,5 & $\mathrm{M}, \mathrm{GM}$ & Recovery \\
\hline Lost River sucker & FE,SL & $\mathrm{C}$ & $1,2,4$ & None ${ }^{1}$ & $\begin{array}{l}\text { Prevent } \\
\text { extinction }\end{array}$ \\
\hline Shortnose sucker & FE,SL & $\mathrm{D}$ & 1,4 & None $^{1}$ & $\begin{array}{l}\text { Prevent } \\
\text { extinction }\end{array}$ \\
\hline Warner sucker & FT,SL & $E$ & 1,4 & $B R, F, I S, M$ & Recovery \\
\hline Borax Lake chub & FE,SL & $\mathrm{F}$ & 1,5 & $\mathrm{M}, \mathrm{RP}$ & Recovery \\
\hline Hutton tui chub & FT,SL & G & 1,5 & None ${ }^{1}$ & $\begin{array}{l}\text { No significant } \\
\text { improvement }\end{array}$ \\
\hline \multicolumn{6}{|c|}{ Other Special Status Fishes } \\
\hline Goose Lake sucker & $\mathrm{C} 2$ & a & 1,4 & None ${ }^{1}$ & $\begin{array}{l}\text { No significant } \\
\text { improvement }\end{array}$ \\
\hline Redband trout & $\mathrm{C} 2$ & $\mathrm{~b}$ & $1,2,4$ & $\begin{array}{l}F, I S, M, P, F P \text {, } \\
\text { PS,RP }\end{array}$ & Recovery \\
\hline Jenny Creek sucker & $\mathrm{C} 2$ & $\mathrm{c}$ & 1,4 & F,SR,GM & Recovery \\
\hline $\begin{array}{l}\text { Klamath largescale } \\
\text { sucker }\end{array}$ & $\mathrm{C} 2$ & d & 1,4 & None $^{1}$ & $\begin{array}{l}\text { Prevent } \\
\text { extinction }\end{array}$ \\
\hline Sheldon tui chub & $\mathrm{C} 2$ & e & 1,5 & F,RP & Recovery \\
\hline $\begin{array}{l}\text { Oregon Lakes tui } \\
\text { chub }\end{array}$ & $\mathrm{C} 2$ & $f$ & 1 & $\mathrm{~F}$ & $\begin{array}{l}\text { Prevent } \\
\text { extinction }\end{array}$ \\
\hline $\begin{array}{l}\text { Summer Basin tui } \\
\text { chub }\end{array}$ & C1 & 9 & $1,4,5$ & $F, S$ & $\begin{array}{l}\text { Prevent } \\
\text { extinction }\end{array}$ \\
\hline $\begin{array}{l}\text { Whitehorse cutthroat } \\
\text { trout }\end{array}$ & $\mathrm{C} 2$ & $\mathrm{~h}$ & 1,5 & F,IS,FP,S,RP & Recovery \\
\hline Bull trout & $\mathrm{C} 2$ & i & 1,4 & $F, M$ & Recovery \\
\hline $\begin{array}{l}\text { Malheur mottled } \\
\text { sculpin }\end{array}$ & $\mathrm{C} 2$ & j & 1 & $F, M$ & Recovery \\
\hline Oregon chub & $\mathrm{C} 2$ & $k$ & 1,4 & None ${ }^{1}$ & $\begin{array}{l}\text { Prevent } \\
\text { extinction }\end{array}$ \\
\hline Sand roller & $S$ & 1 & 1 & None ${ }^{1}$ & $\begin{array}{l}\text { Prevent } \\
\text { extinction }\end{array}$ \\
\hline Mountain sucker & $S$ & $m$ & 1 & None ${ }^{1}$ & $\begin{array}{l}\text { No significant } \\
\text { improvement }\end{array}$ \\
\hline Reticulate sculpin & $S$ & $n$ & 1 & None $^{1}$ & $\begin{array}{l}\text { No significant } \\
\text { improvement }\end{array}$ \\
\hline Piute sculpin & S & o & 1 & None ${ }^{1}$ & $\begin{array}{l}\text { Prevent } \\
\text { extinction }\end{array}$ \\
\hline Slimy sculpin & $S$ & $\mathrm{p}$ & 1 & None ${ }^{1}$ & $\begin{array}{l}\text { No significant } \\
\text { improvement }\end{array}$ \\
\hline Catlow tui chub & $\mathrm{C} 2$ & $q$ & 1 & None ${ }^{1}$ & $\begin{array}{l}\text { Prevent } \\
\text { extinction }\end{array}$ \\
\hline Alvord chub & $\mathrm{C} 2$ & $r$ & 1,4 & $F, G M$ & Recovery \\
\hline
\end{tabular}


Locations of Special Status Fishes on BLM Lands in Oregon

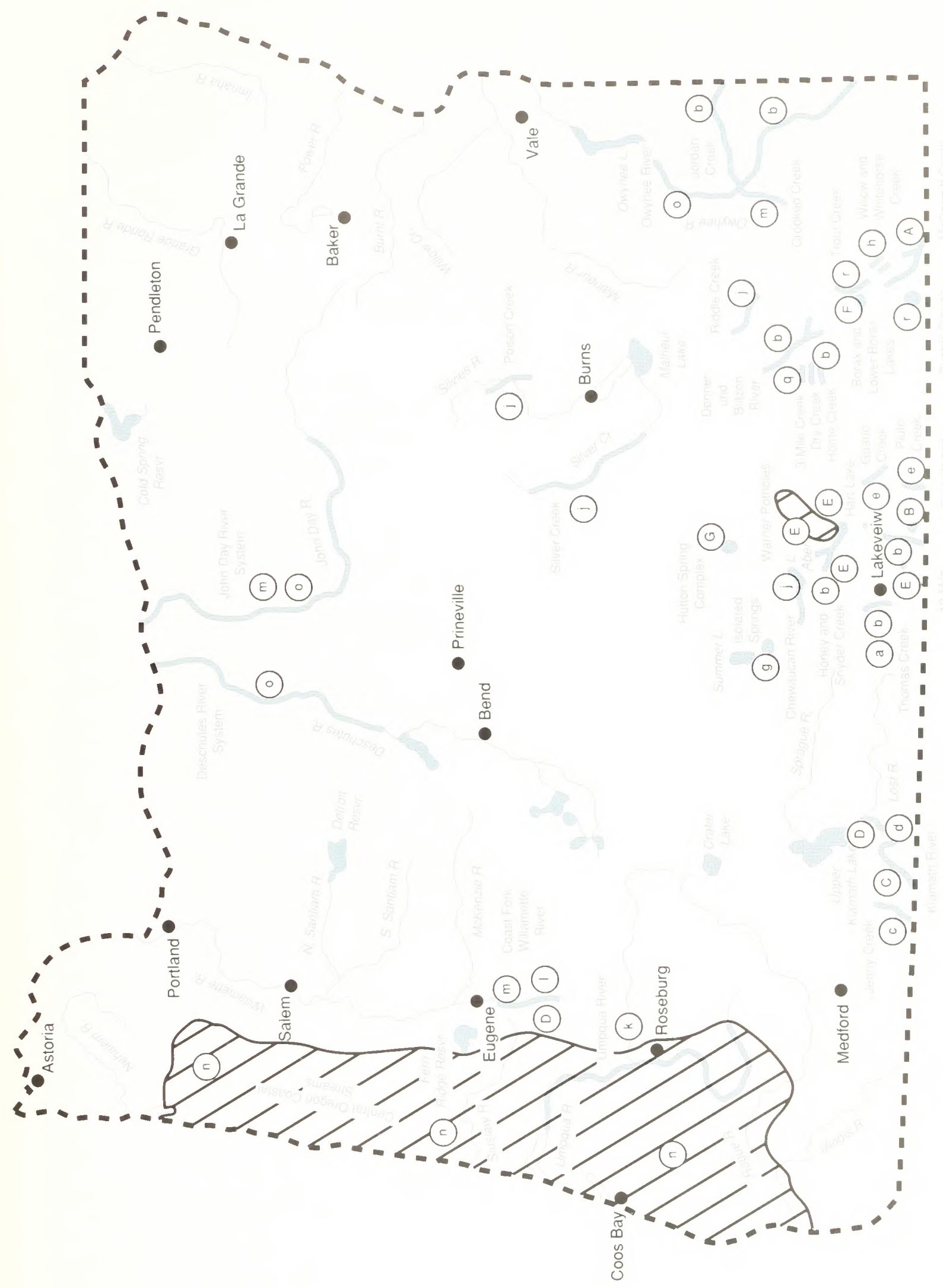


Table 15. Special status fishes of Utah.

\begin{tabular}{|c|c|c|c|c|c|}
\hline \multicolumn{6}{|c|}{ Threatened or Endangered } \\
\hline Fish & $\begin{array}{l}\text { Present } \\
\text { Status }\end{array}$ & $\begin{array}{c}\text { Map } \\
\text { Symbol }\end{array}$ & Threats & $\begin{array}{c}\text { Habitat } \\
\text { Improvements }\end{array}$ & $\begin{array}{c}\text { Plan } \\
\text { Results }\end{array}$ \\
\hline $\begin{array}{l}\text { Lahontan cutthroat } \\
\text { trout }\end{array}$ & $\mathrm{FT}$ & $A$ & 1,4 & $F, M, I S$ & Recovery \\
\hline Woundfin & FE & B & $1,3,4$ & $X R, M$ & $E$ to $T$ \\
\hline Virgin River chub & $\mathrm{FE}$ & C & 1 & $X R, M$ & $E$ to $T$ \\
\hline Colorado squawfish & $\mathrm{FE}$ & $\mathrm{D}$ & $1,3,4$ & $\mathrm{~S}$ & $\begin{array}{l}\text { Prevent } \\
\text { extinction }\end{array}$ \\
\hline Bonytail chub & FE & $E$ & 1,4 & $\mathrm{~S}$ & $\begin{array}{l}\text { No significant } \\
\text { improvement }\end{array}$ \\
\hline Humpback chub & FE & $\mathrm{F}$ & 1,4 & $\mathrm{~S}$ & $\begin{array}{l}\text { No significant } \\
\text { improvement }\end{array}$ \\
\hline June sucker & $\mathrm{FE}$ & G & $1,4,5$ & $M$ & $\begin{array}{l}\text { No significant } \\
\text { improvement }\end{array}$ \\
\hline \multicolumn{6}{|c|}{ Other Special Status Fishes } \\
\hline Virgin River spinedace & $\mathrm{C} 2$ & a & 1,4 & $X R, M$ & $\begin{array}{l}\text { Prevent } \\
\text { extinction }\end{array}$ \\
\hline $\begin{array}{l}\text { Bonneville cutthroat } \\
\text { trout }\end{array}$ & $\mathrm{C} 2$ & $\mathrm{~b}$ & 1,4 & M,IS & Recovery \\
\hline Razorback sucker & PE & c & $1,2,4$ & $X R, S$ & $\begin{array}{l}\text { Prevent } \\
\text { extinction }\end{array}$ \\
\hline Leatherside chub & $\mathrm{C} 2$ & d & 1 & None $^{1}$ & $\begin{array}{l}\text { No significant } \\
\text { improvement }\end{array}$ \\
\hline $\begin{array}{l}\text { Colorado cutthroat } \\
\text { trout }\end{array}$ & $\mathrm{C} 2$ & $\mathrm{e}$ & 1,4 & $\mathrm{BR}, \mathrm{XR}, \mathrm{F}, \mathrm{IS}$ & Recovery \\
\hline Least chub & $\mathrm{C} 1$ & $f$ & 1,4 & GM,F & $\begin{array}{l}\text { Prevent } \\
\text { extinction }\end{array}$ \\
\hline
\end{tabular}




\section{Locations of Special Status Fishes on BLM Lands in Utah}

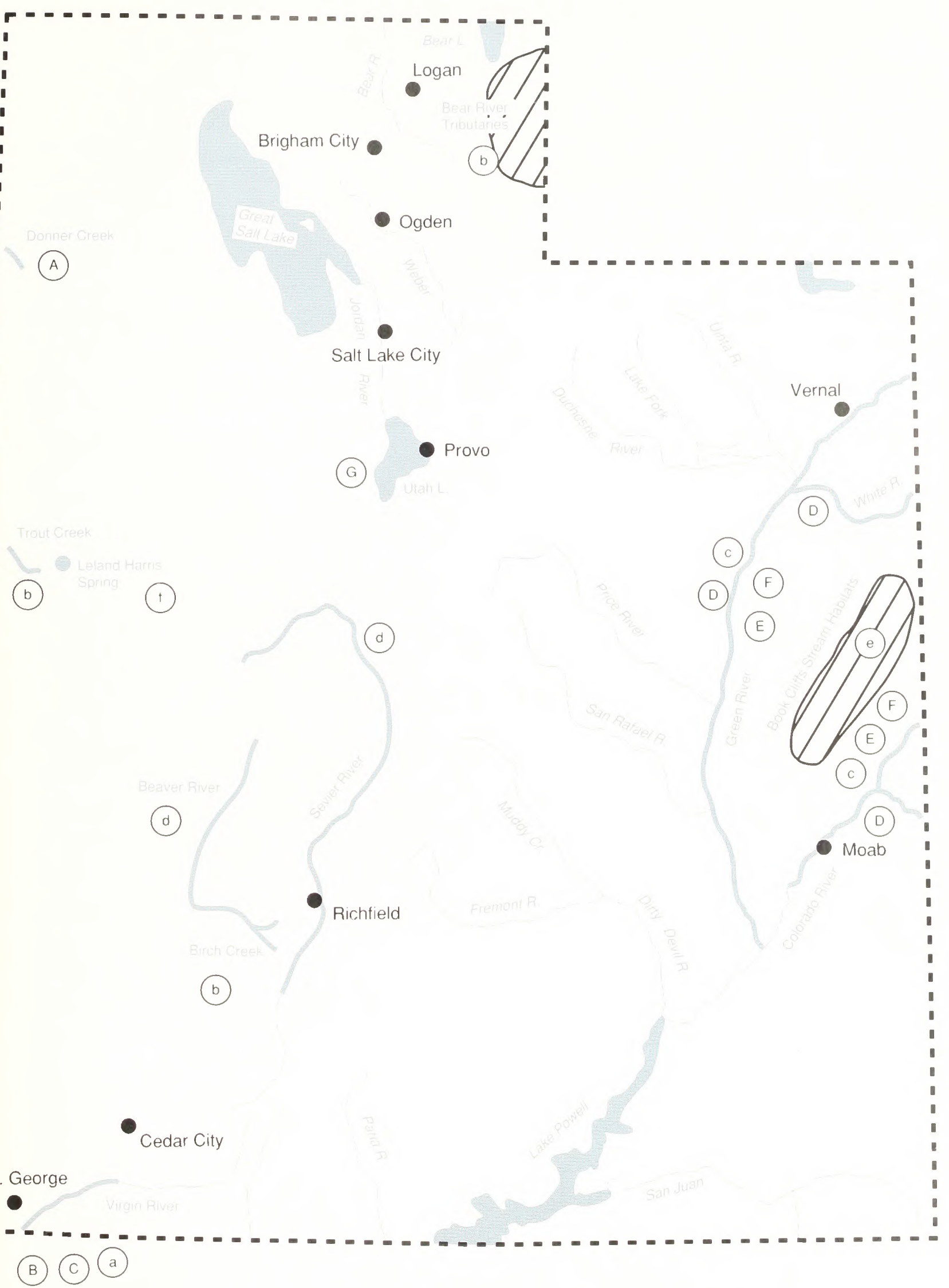


Table 16. Special status fishes of Wyoming.

\begin{tabular}{|c|c|c|c|c|c|}
\hline \multicolumn{6}{|c|}{ Threatened or Endangered } \\
\hline Fish & $\begin{array}{l}\text { Present } \\
\text { Status }\end{array}$ & $\begin{array}{c}\text { Map } \\
\text { Symbol }\end{array}$ & Threats & $\begin{array}{c}\text { Habitat } \\
\text { Improvements }\end{array}$ & $\begin{array}{c}\text { Plan } \\
\text { Results }\end{array}$ \\
\hline Colorado squawfish & FE & A & $1,3,4$ & None $^{1}$ & $\begin{array}{l}\text { Prevent } \\
\text { extinction }\end{array}$ \\
\hline Bonytail chub & $\mathrm{FE}$ & $\mathrm{B}$ & 1,4 & None $^{1}$ & $\begin{array}{l}\text { Prevent } \\
\text { extinction }\end{array}$ \\
\hline $\begin{array}{l}\text { Kendall warm springs } \\
\text { dace }\end{array}$ & FE & $\mathrm{C}$ & 5 & None $^{1}$ & $\begin{array}{l}\text { No significant } \\
\text { improvement }\end{array}$ \\
\hline \multicolumn{6}{|c|}{ Other Special Status Fishes } \\
\hline $\begin{array}{l}\text { Bonneville cutthroat } \\
\text { trout }\end{array}$ & $\mathrm{C} 2$ & a & 1,4 & F,IS,GM,S & Recovery \\
\hline $\begin{array}{l}\text { Colorado cutthroat } \\
\text { trout }\end{array}$ & $\mathrm{C} 2$ & $b$ & 1,4 & $\mathrm{BC}, \mathrm{M}, \mathrm{GM}, \mathrm{BT}, \mathrm{F}$ & Recovery \\
\hline Sturgeon chub & $\mathrm{C} 2$ & $\mathrm{C}$ & 1 & $\mathrm{~F}, \mathrm{GM}$ & Recovery \\
\hline Razorback sucker & PE & $d$ & 1,2 & S,D & $\begin{array}{l}\text { Prevent } \\
\text { extinction }\end{array}$ \\
\hline
\end{tabular}


Locations of Special Status Fishes on BLM Lands in Wyoming

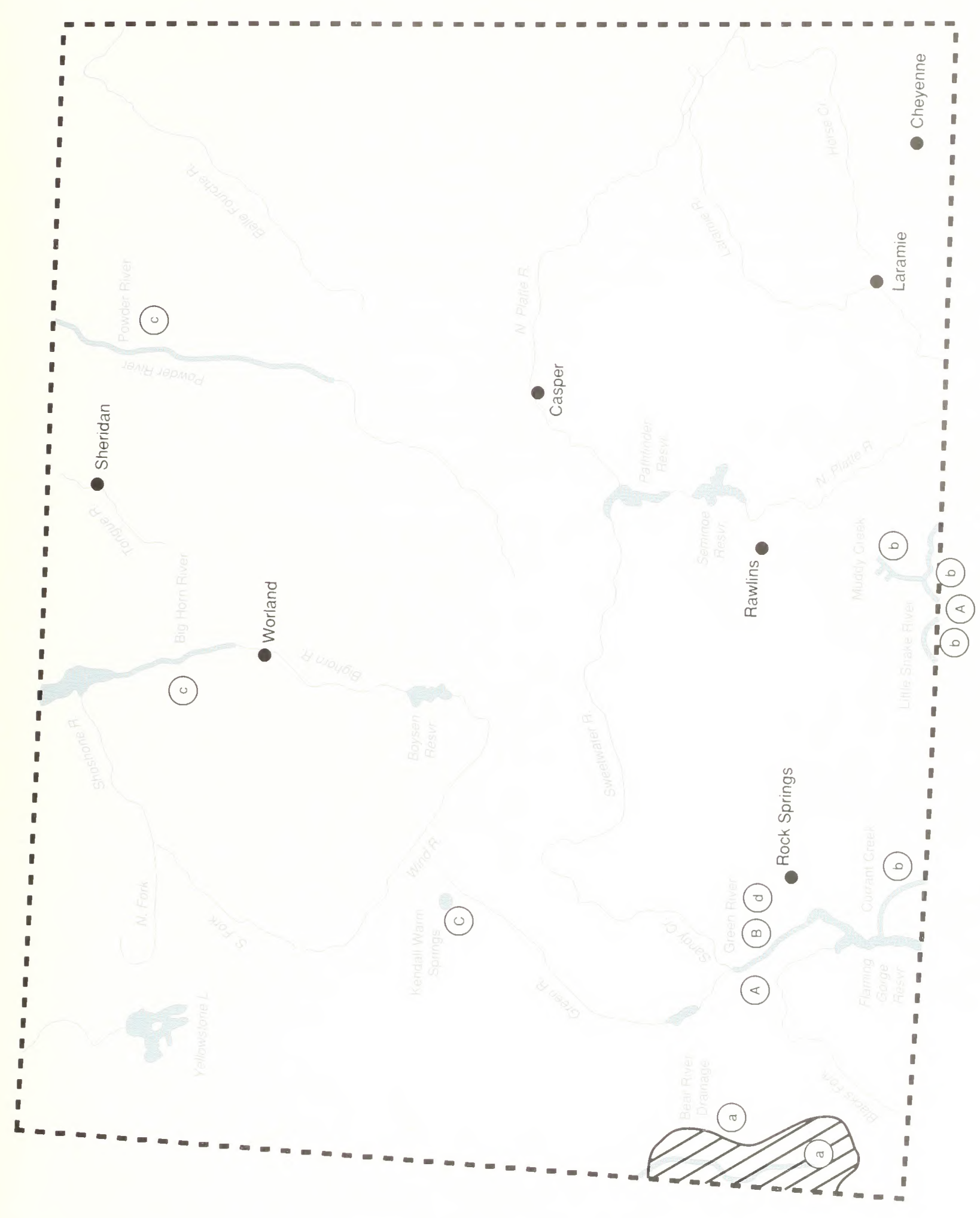





\section{Personnel and Funding Needs}

\section{Personnel Needs}

Approximately 320 work years are identified in this plan for implementation of the special status fish strategy during fiscal years 1991-2000 (Table 17). Not all of this staff time would be allocated to fishery biologists. Portions would be needed for engineering fish barriers, conducting assessments for land exchanges and acquisitions, and other activities necessary to meet the goals of the strategy.

In order to implement the program, additional field expertise in fisheries is needed at all levels. In the past decade, the Bureau has lost about two-thirds of its fisheries positions, so that few offices presently have fisheries expertise. This is particularly true in states where most of the special status fishes are located.
As of December 1989, 40 fisheries biologists were employed by BLM, about 25 percent less than employed by the Bureau 10 years ago. Nearly one-third of these, 13 biologists, are located in Oregon. Although no states have sufficient staff to effectively manage special status fishes and their habitats, the situation is most critical in Nevada, where 3 fisheries biologists are responsible for 28 special status fishes on public lands (Figure 1). Arizona and New Mexico, both of which have substantial special status fish workloads, lack BLM fisheries biologists. The number of fisheries biologists needed for implementation of Fish and Wildlife 2000 is estimated at 142. This includes biologists for special status fishes, anadromous fishes, resident fisheries, and riparian management.

\section{Number of BLM Fisheries Biologists}

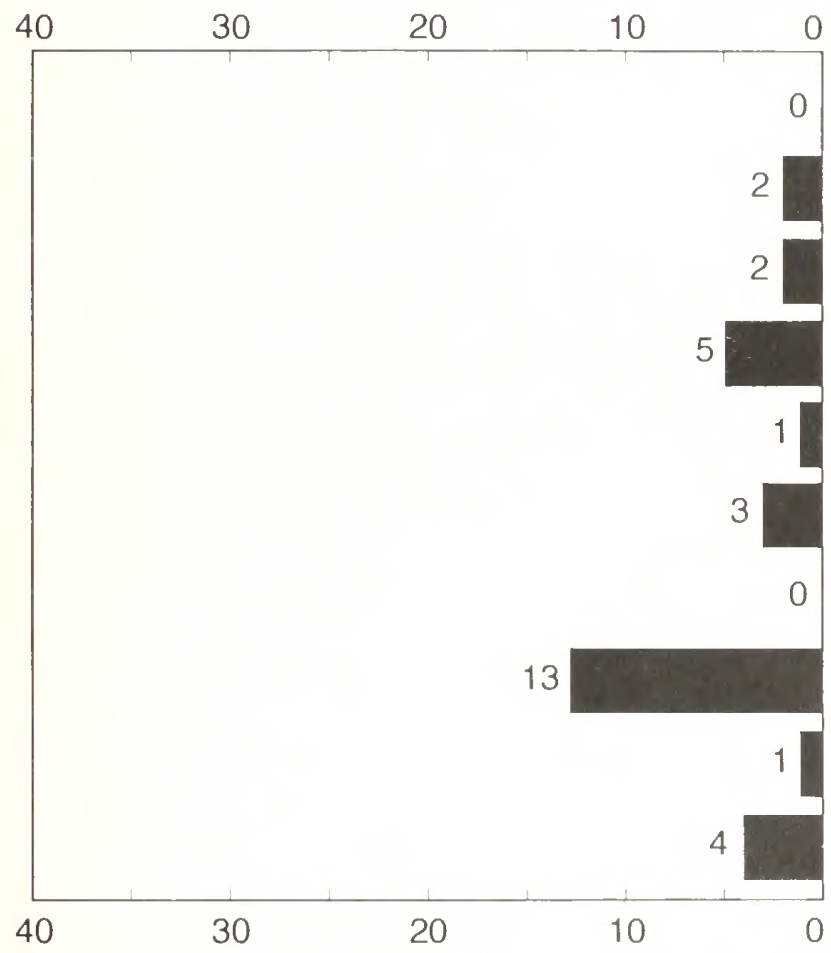

$A Z$

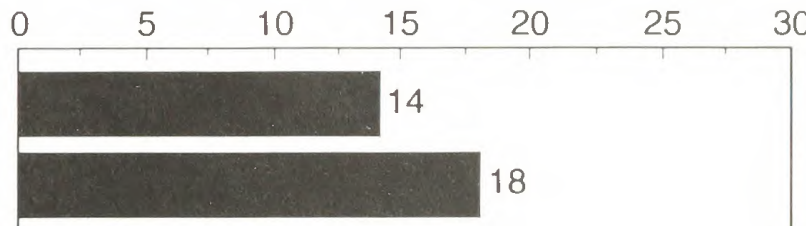

$\mathrm{CO}$

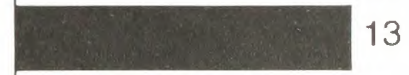

ID

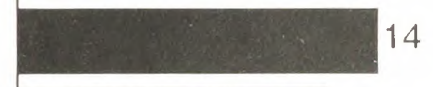

\section{MT}

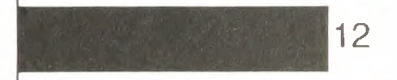

NV

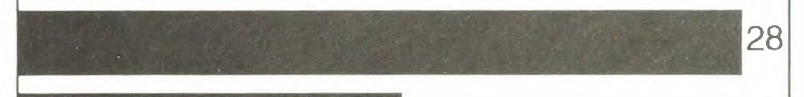

NM

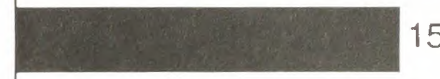

OR

UT

WY

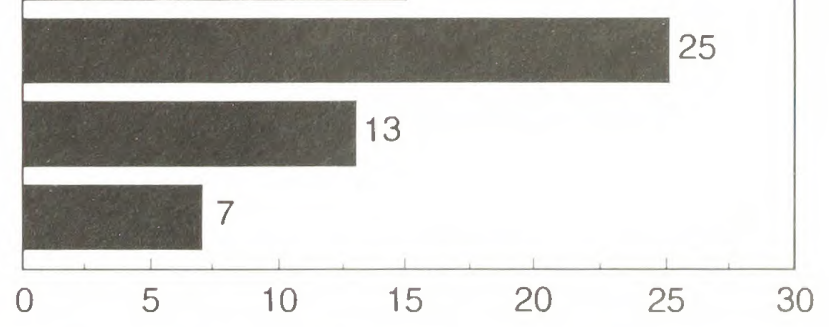

Figure 1. Number of BLM fisheries biologists by state in 1989 versus number of special status fishes on public lands in that state. BLM fisheries biologists in Alaska, Washington Office, and Denver Service Center are not included. 


\section{Program Costs}

The total cost for plan implementation for fiscal years 1991 to 2000 is estimated to be about $\$ 53.5$ million (Table 17). This total includes approximately $\$ 2.2$ million for inventory needs, $\$ 1.4$ million for development of new activity plans, $\$ 11.0$ million for habitat improvements, $\$ 34.3$ million for habitat and water rights acquisition, $\$ 2.3$ million for monitoring, and $\$ 2.2$ million for research. These costs could be reduced by extensive use of challenge cost-sharing, volunteer programs, MOUs, and cooperative agreements with other resource agencies.

Table 17. Summary of plan implementation costs.

\begin{tabular}{|c|rrrrrrr|}
\hline State & $\begin{array}{c}\text { Inventory } \\
\$ 000\end{array}$ & $\begin{array}{c}\text { New Plans } \\
\mathbf{\$ 0 0 0}\end{array}$ & $\begin{array}{c}\text { Habitat } \\
\text { Improvements } \\
\mathbf{\$ 0 0 0}\end{array}$ & $\begin{array}{c}\text { Acquisition } \\
\mathbf{\$ 0 0 0}\end{array}$ & $\begin{array}{c}\text { Monitoring } \\
\mathbf{\$ 0 0 0}\end{array}$ & $\begin{array}{c}\text { Research } \\
\mathbf{\$ 0 0 0}\end{array}$ & $\begin{array}{c}\text { Total } \\
\mathbf{\$ 0 0 0}\end{array}$ \\
\hline AZ & 517 & 112 & 1,653 & 11,057 & 279 & 516 & 14,134 \\
\hline CA & 125 & 49 & 729 & 5,541 & 83 & 315 & 6,842 \\
\hline CO & 159 & 192 & 375 & 853 & 357 & 346 & 2,282 \\
\hline ID & 205 & 294 & 2,130 & 1,291 & 326 & 579 & 4,825 \\
\hline MT & 270 & 126 & 444 & 147 & 34 & 56 & 1,077 \\
\hline NM & 92 & 18 & 301 & 1,500 & 6 & 25 & 1,942 \\
\hline NV & 230 & 342 & 2,400 & 10,172 & 215 & 101 & 13,460 \\
\hline OR/WA & 347 & 140 & 1,439 & 3,277 & 518 & 144 & 5,865 \\
\hline UT & 69 & 68 & 813 & 434 & 277 & 55 & 1,716 \\
\hline WY & 210 & 100 & 740 & 60 & 163 & 100 & 1,373 \\
\hline \hline Total & 2,224 & 1,441 & 11,024 & 34,332 & 2,258 & 2,237 & 53,516 \\
\hline Wk.Yrs. & 48.4 & 39.8 & 107.3 & 37.2 & 51.8 & 35.8 & 320.3 \\
\hline
\end{tabular}




\section{Summary}

Overall benefits of implementing this strategy can be expressed in terms of the species and populations of special status fishes that are maintained, expanded, or recovered. The Department of the Interior currently lists 39 fishes on public lands as endangered or threatened. Full implementation of this plan would result in complete recovery of $1 \mathrm{I}$ and reclassification of 8 other species from endangered to threatened. This estimate depends on acquisition of one or two key parcels of private land adjacent to public lands for the Borax Lake chub (Gila boraxobius), White River springfish (Crenichthys baileyi), Hiko springfish, Railroad Valley springfish, Pahrump poolfish, Big Spring spinedace (Lepidomeda molhispinis pratensis), and desert dace (Eremichthys acros). Funds have been appropriated in fiscal year 1990 for acquisition of desert dace habitat. Implementation would also prevent the extinction of 11 other listed fishes.

Of the 73 other special status fishes that are not Federally listed, 21 would be recovered. This would prevent the need to list 18 candidate species and would enable 6 others to be removed from State listings. For 33 of those fishes where complete recovery cannot be achieved, some recovery actions could be taken on public lands that would prevent their extinction. BLM has insufficient ownership of habitat to significantly improve recovery of 15 other special status fishes.

Public lands afford numerous opportunities lor translocations of special status lish stocks for many species whose existing ranges occur primarily outside BLM jurisdiction. The number of special status fishes potentially benefiting from BLM participation in

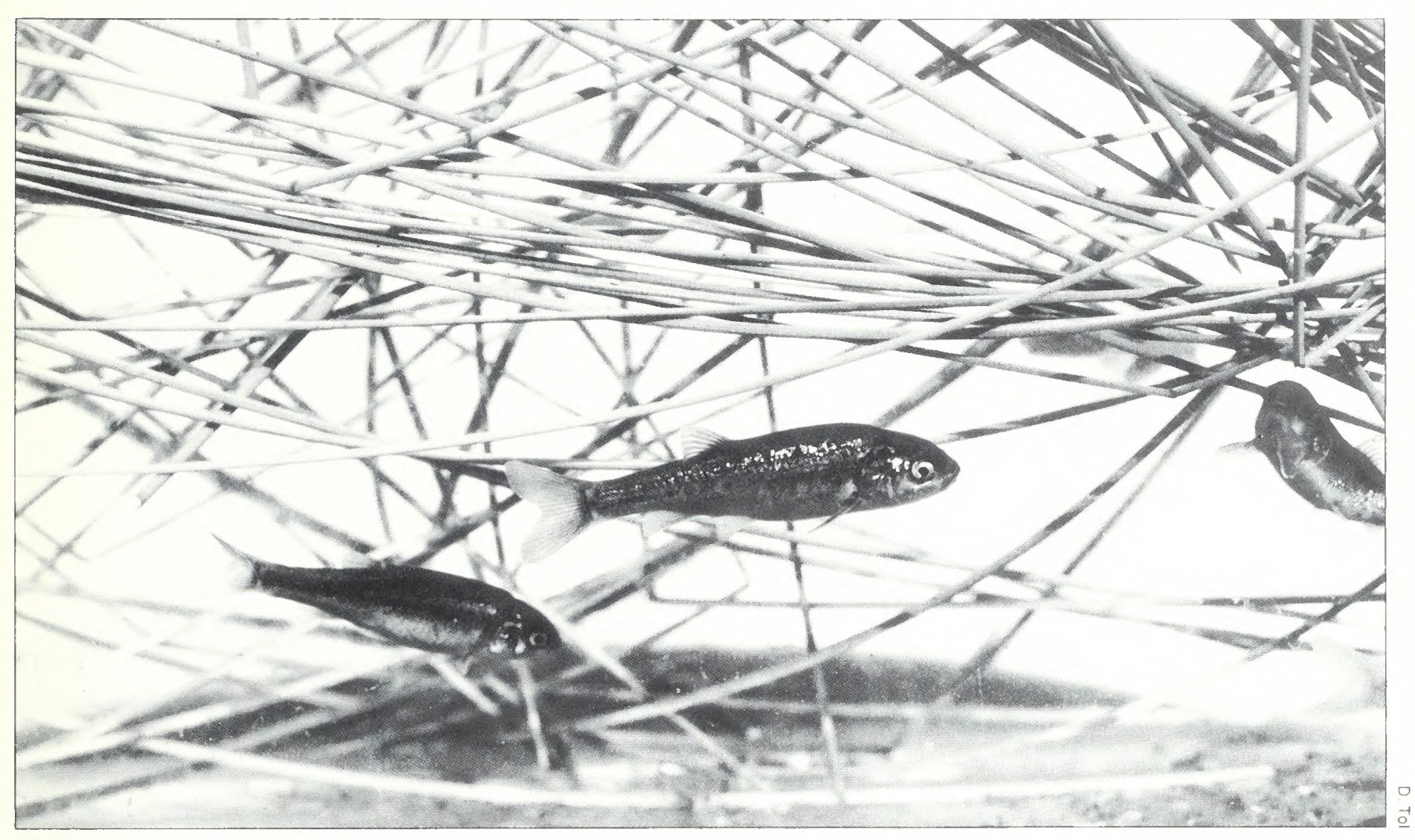

Desert Dace. Endemic to thermal springs in Soldiers Meadow in northwestern Nevada. Hot water temperatures and long isolation of habitats have resulted in speciation of this form to the level of a monotypic genus,

Eremichthys. 
recovery programs, therefore, is greater than indicated in this plan.

In the case of special status specics, economic benefits may appear limited, but include substantial sport fishing opportunities by enhancing numerous subspecies of special status trouts. Interpretive facilities could be incorporated around special status fish habitats. Springs containing pupfish, for example, make fascinating displays for watchable wildlife programs. Society has shown a willingness to maintain species and their habitats for a variety of cultural, scientific, aesthetic, and spiritual values, even if it increases economic costs of management.

Implementation of actions described in this plan, in association with other resource agencies and organizations, will prevent social, biological, and aesthetic losses caused by degraded aquatic habitats and continued erosion of our nation's biodiversity. Management of the special status fish resource would become more efficient. Flexibility of BLM field managers in land management would increase as listed species are recovered and candidate species improve in status. Numerous other aquatic and riparian-dependent species would benefit from actions described in this plan.

\section{Summary of Plan Implementation Benefits}

If this plan is successfully implemented, the following benefits are expected:

\section{Federally Listed Species}

- Completely recover 11 fish species

- Reclassify 8 fish species from endangered to threatened

- Prevent extinction of 11 additional fish species

\section{Other Special Status Fish Species}

- Prevent the necd to list 18 candidate fish species

- Complete recovery of 6 State-listed fish species

- Prevent extinction of 33 additional fish species 


\section{Bibliography}

The following articles and books are recommended as sources of information on rare fishes of the West and on management strategies for their conservation.

Allendorf, F.W. and R.F. Leary. 1988. Conservation and distribution of genetic variation in a polytypic species, the cutthroat trout. Conservation Biology. 2:170-184.

Bureau of Land Management Fish Habitat Management Team. 1989. Fisheries habitat management on public lands: A strategy for the future. USDI, Bureau of Land Management, Washington, D.C. $36 \mathrm{pp}$.

Conant, S. 1988. Saving endangered species by translocation: are we tinkering with evolution? BioScience. 38:254-257.

Gresswell, R.E. (ed.). 1988. Status and management of interior stocks of cutthroat trout. American Fisheries Society Symposium No. 4. Bethesda, Maryland. $140 \mathrm{pp.}$

Hubbs, C.L., R.R. Miller, and L.C. Hubbs. 1974. Hydrographic history and relict fishes of the northcentral Great Basin. Memoirs California Academy Sciences. 7:1-259.

Meffe, G.K. 1987. Conserving fish genomes: Philosophies and practices. Environmental Biology Fishes. 18:3-9.

Meffe, G.K. and R.C. Vrijenhoek. 1988. Conservation genetics in the management of desert fishes. Conservation Biology. 2:157-169.

Miller, R.R. 1961. Man and the changing fish fauna of the American Southwest. Papers Michigan Academy Science Arts Letters. 46:365-404

Miller, R.R., J.D. Williams, and J.E. Williams. 1989. Extinction of North American fishes during the past century. Fisheries. 14(6):22-38.
Minckley, W.L. and J.E. Deacon (eds.). 1991. Battle against extinction: Native fish management in the American West. University of Arizona Press, Tucson. $500 \mathrm{pp}$.

Naiman, R.J. and D.L. Soltz (eds.). 1981. Fishes in North American deserts. John Wiley and Sons, Inc. New York. 552 pp.

Pimm, S.L., H.L. Jones, and J. Diamond. 1988. On the risk of extinction. American Naturalist. 132:757-785.

Ryman, N. and F. Utter (eds.). 1987. Population genetics and fishery management. University of Washington Press, Seattle. 420 pp.

Sigler, W.F. and J.W. Sigler. 1987. Fishes of the Great Basin, a natural history. University of Nevada Press, Reno. 425 pp.

Trotter, P.C. 1987. Cutthroat: Native trout of the West. Colorado Associated University Press. Boulder, Colorado.

Williams, J.E., D.W. Sada, C.D. Williams, and others. 1988. American Fisheries Society guidelines for introductions of threatened and endangered fishes. Fisheries. 13(5):5-11.

Williams, J.E., J.E. Johnson, D.A. Hendrickson, S. Contreras-Balderas, J.D. Williams, M. NavarroMendoza, D.E. McAllister, and J.E. Deacon. 1989. Fishes of North America: endangered, threatened, or of special concern. Fisheries. 14(6):2-20.

USDI, Bureau of Land Management. 1987. Fish and Wildlife 2000: A plan for the Future. Washington, D.C. $30 \mathrm{pp}$. 



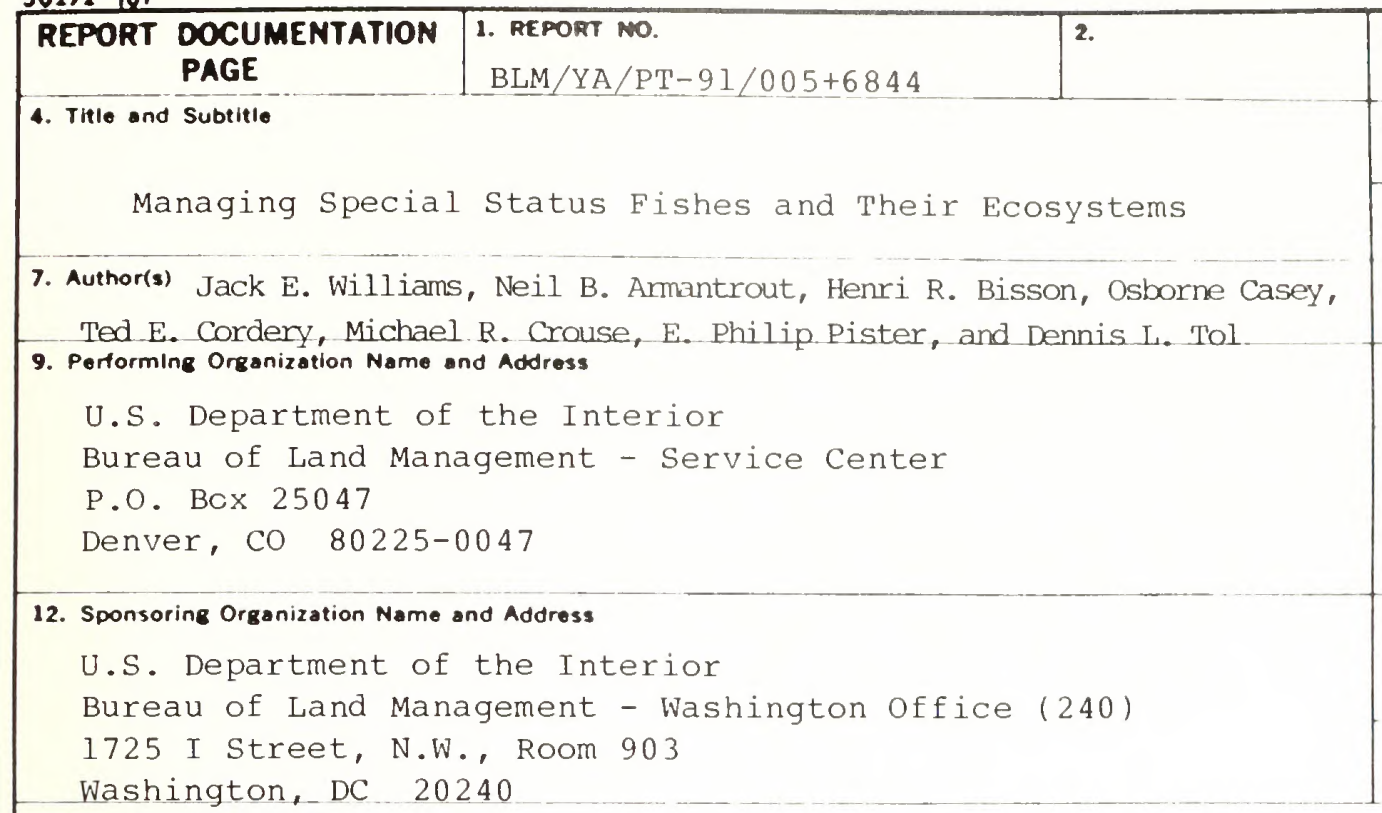

3. Recipient's Accession No.
9. Report Date
May 1991
a. Penorming Organlzation Ropt. No.

a. Penorming Organlzation Rept. No.

10. Prolect/Task/Work Unit No.

11. Contract(C) or Grant(G) No.

(C)

(G)

13. Type of Report \& Period Covered

15. Supplementary Notes

16. Abstract (Limit: 200 words)

This report outlines a strategy for the management of public lands to protect and enhance the habitats of endangered and threatened fish species in the western United States. The strategy would assist in maintaining, expanding, or recovering the populations. Full implementation would result in complete recovery of 11 species and reclassification of 8 others. Another 11 species would be removed from danger of extinction.

17. Document Analysis ascriptors

Endangered species

Fishes

Aquatic habitats

b. Identifiers/Open-Ended Terms

Public lands

Western United States

Biodiversity

c. COSATI Field/Group

18. Avallabllity Statemen:

Release Unlimited

19. Socurity Class (This Report)

Unclassified

20. Security Class (This Pago)

Unclassified.
21. No. of Pages 65

22. Price 



BLMLIBRARY

BLDG 50, ST-150A

DENVER FEDERAL CENTER

DENVER. COLORADO 80225
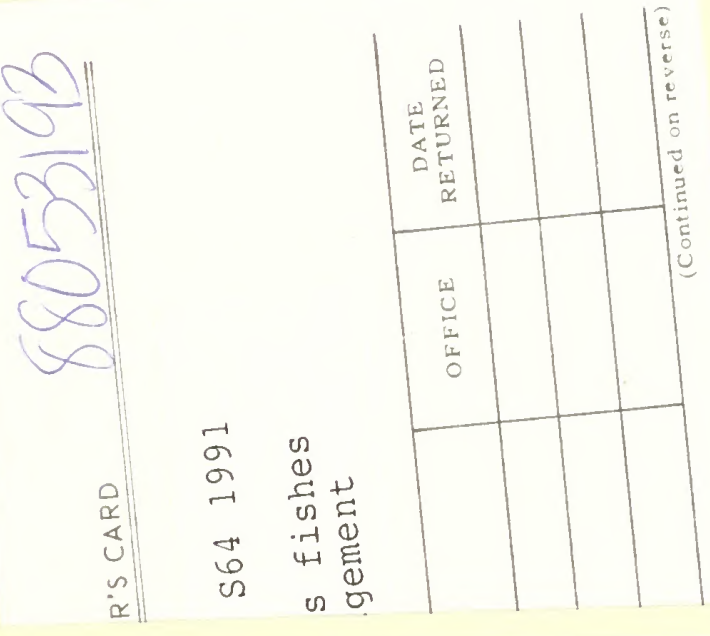

QL 617.73 .U6 S64 1991

Special status fishes

habitat management

BLM LIBRARY

BLDG 50, ST-150A

DENVER FEDERAL CENTER

P.O. BOX 25047

DENVER, COLORADO 80225

RECEIVED 


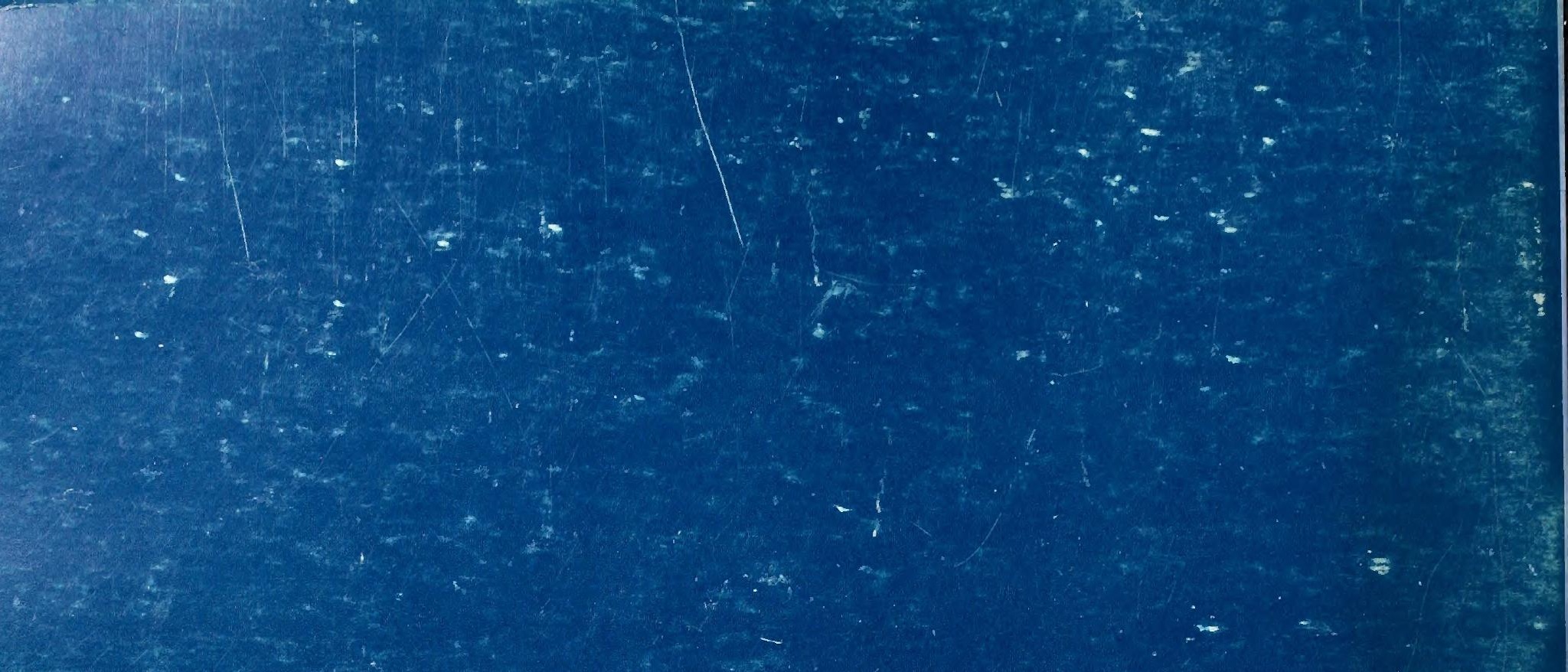

